\title{
Taxonomic revision of Galeocharax (Characiformes: Characidae: Characinae)
}

\author{
Victor Giovannetti ${ }^{1}$, Mônica Toledo-Piza ${ }^{1}$ and Naércio A. Menezes ${ }^{2}$
}

The taxonomy of Galeocharax, a genus of freshwater fishes distributed in most South American cis-Andean river systems, except the rio Negro, rio São Francisco and rio Xingu basins and the eastern drainages of Brazil, is herein revised. A total of 1229 specimens were examined from which 680 had meristic and morphometric data taken. Osteological and morphological features were also examined through radiographs, scanning electron microscopy and in cleared and stained specimens. Three of the four species previously considered as valid are herein recognized: Galeocharax humeralis from rio Paraguay and lower rio Paraná basins; Galeocharax goeldii, from rio Madeira basin, with records of geographical distribution expanded to the río Madre de Dios, río Beni, rio Mamoré and rio Guaporé basins and Galeocharax gulo, which is widespread throughout rio Amazonas, río Orinoco, rio Tocantins, and upper rio Paraná basins. Galeocharax knerii is herein considered a junior synonym of Galeocharax gulo. A key to species of Galeocharax is presented.

Keywords: Key of identification, Ostariophysi, Systematics, Widespread species.

A taxonomia de Galeocharax, um gênero de peixes de água doce distribuído nos principais sistemas hídricos da América do Sul cisandina, com exceção da bacia do rio Negro, do rio São Francisco, do rio Xingu e das drenagens litorâneas do leste, é aqui revisada. Foram examinados 1229 exemplares, dos quais 680 tiveram dados merísticos e morfométricos tomados. Características osteológicas e morfológicas também foram examinadas por meio de radiografias, microscopia eletrônica de varredura e exemplares diafanizados. Três das quatro espécies previamente consideradas válidas são reconhecidas: Galeocharax humeralis das bacias do rio Paraguai e baixo rio Paraná; Galeocharax goeldii da bacia do rio Madeira, com registros de distribuição geográfica ampliados para as bacias dos rios Madre de Dios, Beni, Mamoré e Guaporé, e Galeocharax gulo amplamente distribuída nas bacias dos rios Amazonas, Orinoco, Tocantins e alto rio Paraná. Galeocharax knerii foi considerada sinônimo júnior de Galeocharax gulo. Uma chave de identificação para as espécies de Galeocharax é apresentada.

Palavras-chave: Chave de identificação, Espécies amplamente distribuídas, Ostariophysi, Sistemática.

\section{Introduction}

Galeocharax Fowler, 1910 is a genus of freshwater fishes that reach up to $25 \mathrm{~cm}$ in length. They are popularly known as "saicanga", "peixe-cigarra", "peixe-cadela", and "dentudo" in the Brazilian territory (Graça, Pavanelli, 2007; Langeani, Rêgo, 2014) and as “dentón" and "dientón alargado" in Peru and Venezuela (Taphorn, 1992; Ortega et al., 2012). Species of the genus are found in most of the main river systems of the cis-Andean South America with the exception of the rio São Francisco, rio Negro, rio Xingu basins, and the eastern drainages of Brazil.

They are carnivorous, feeding on small fishes and invertebrates (Ribeiro Neto et al., 1998; Gandini et al., 2012). They reproduce throughout the year and there is no record of parental care or migratory behavior (Magalhães et al., 2004). The presence of the parasitic isopoda (Braga cigarra, Cymothoidae), popularly known as "cigarrinha", in the oral cavity of specimens of Galeocharax in the Paraná basin is fairly common (Brandão et al., 2013), justifying the popular name peixe cigarra.

The genus Galeocharax is included in the family Characidae, which is the most species rich family in the order Characiformes with approximately 165 genera and more than 1300 species (Nelson et al., 2016), from which more than 600 occur in the Brazilian territory (Buckup et al., 2007). Within the Characidae, Galeocharax has been traditionally included in the subfamily Characinae (Lucena, Menezes, 2003; Mirande, 2010; Mattox, Toledo-Piza, 2012), and more closely related to Acestrocephalus Eigenmann and Cynopotamus Valenciennes, all three genera forming a monophyletic taxon that currently includes 24 species, diagnosed, among other features, by the presence of spinoid scales (Menezes, 1976).

\footnotetext{
${ }^{1}$ Departamento de Zoologia, Instituto de Biociências, Universidade de São Paulo, Rua do Matão, Travessa 14, n 101, 05508-090 São Paulo, SP, Brazil. (VG) vgiovannetti@gmail.com (corresponding author), (MTP) mtpiza@usp.br

${ }^{2}$ Museu de Zoologia, Universidade de São Paulo. P. O. Box 42494, 04218-970 São Paulo, SP, Brazil. naercio@usp.br
} 
The latest taxonomic revision of the genus was carried out by Menezes (1976) who recognized three valid species: Galeocharax humeralis (Valenciennes, 1834) from the rio Paraguai and the lower rio Paraná basins; Galeocharax gulo (Cope, 1870) from the rio Amazonas and the rio Tocantins basins and Galeocharax knerii (Steindachner, 1879) from the upper rio Paraná basin. At that time, Menezes considered Galeocharax goeldii (Fowler, 1913) from the rio Madeira basin, as a synonym of G. gulo, but more recently, after the examination of additional specimens, the species was recognized as valid (Menezes, 2007a).

More recent revisions of Acestrocephalus and Cynopotamus resulted in the descriptions of new species (Menezes 1987, 2006, 2007b). Moreover, Taphorn (1992: 185) suggested that specimens of Galeocharax from the río Apure, in the río Orinoco drainage, Venezuela, could represent an undescribed species.

The number of specimens of Galeocharax available in ichthyological collections increased considerably in the past decades, showing that the genus is more widely distributed than previously recorded. Therefore, the aim of the present study was to undertake a taxonomic study of the genus including the highest number of specimens as possible in order to determine how many and which species can be recognized as valid, to reevaluate their diagnostic features and to estimate their geographic distribution.

\section{Material and Methods}

A total of 1229 specimens deposited in several ichthyological collections and covering the entire area of distribution of Galeocharax were examined, from which 680 specimens had meristic and morphometric data taken. Morphometric data were taken point to point with a digital caliper with $0.1 \mathrm{~mm}$ precision, on the left side of the specimen, whenever possible. Nineteen different measurements were made on each specimen and they are presented in the tables and text as percentages of standard length (SL), with the exception of measurements of subunits of the head, which were expressed as percentages of head length (HL).

Data of specimens from which sex could be determined based on the examination of gonads were initially analyzed separately to check for possible sexual dimorphism, but are presented together in the tables and text since no differences were detected. Variation of the number of teeth on the posterior row of the dentary is only partially associated with growth, and was represented by scatter plots. The same association was observed for number of maxillary teeth.

Measurements follow Menezes (1969), with the exception of: head length, which was measured from the tip of the snout to the posterior bony margin of the opercle at the ventral tip of the opercle concavity. The following measurements were included: upper jaw length: distance between the tip of the snout and posterior margin of the maxilla. Dorsal-fin length: distance between the base of the first ray and the distal tip of the longest unbranched ray. Dorsal-fin base length: distance between the bases of the anterior- and posteriormost dorsal-fin rays. Anal-fin length: distance between the base of the first visible unbranched ray and the distal tip of the longest unbranched ray. Analfin base length: distance between the bases of the anteriorand posteriormost anal-fin rays. Prepectoral distance: distance between the tip of the snout and the base of the first pectoral-fin ray. Caudal-peduncle length: distance between the base of the posteriormost anal-fin ray and the posterior margin of the hypural plate.

Meristic data were taken from the left side of specimens whenever possible. Scales, fin-rays and teeth were counted with the aid of a stereomicroscope. The number of unbranched rays is expressed with roman numerals and the number of branched rays with arabic numerals. For a better visualization of the teeth, a solution of methylene blue in $70 \%$ ethanol was applied to the specimens. The stain is temporary and fades away a few minutes after returning the specimen to $70 \%$ ethanol. Counts of vertebrae and supraneurals were made on radiographs taken from a limited number of specimens and examined in the RadiAnt DICOM viewer (32-bit) software.

Counts follow Menezes (1969) with the exception of number of scales below the lateral line that was counted as the number of horizontal rows of non-perforated scales between the lateral line and the base of the first pelvicfin ray. This way of counting showed to be more precise than that made at the vertical through the first anal fin ray, since the scales in this latter region tended to be slightly disorganized. The following counts were added: number of scales around the caudal peduncle; number of scales in the anal-fin sheath: number of horizontal rows on the sheath of scales that covers the base of the anal-fin rays; number of pelvic-fin rays; number of teeth on the outer row of the dentary; number of teeth on the inner row of the dentary; number of teeth on the outer row of the premaxilla; number of teeth on the inner row of the premaxilla; total number of vertebrae; number of abdominal vertebrae: including the four anteriormost vertebrae of the Webberian apparatus until the posteriormost vertebra without a haemal spine and number of caudal vertebrae (from the first vertebra with a haemal spine to the compound ural centrum, which was counted as one). Counts of unbranched anal-fin rays, principal and procurrent caudal-fin rays were made only on cleared and stained specimens. In the descriptions, meristic values are followed by their respective frequency in parentheses, except those presented on tables.

Meristic and morphometric data were summarized using descriptive statistics with the help of MYSTAT 12 software.

Morphological details of spinoid scales, sensu Roberts (1993), and bony hooks on the anal- and pelvic-fin rays were examined through scanning electronic microscope 
images made in a Zeiss DSM940 electronic microscope. Since no diagnostic differences were observed, details of those structures are shown for a single species.

Specimens were cleared and stained following the procedure of Taylor, Van Dyke (1985).

Specimens from the same locality were initially compared and if differences on the examined characteristics were not detected they were grouped. This approach was carried out successively for localities near to each other, then to localities on the same river basins until all the specimens were analyzed and preliminary groups were defined.

In the discussion of geographic distribution, the Amazon basin was defined excluding the rio Tocantins (see Goulding et al., 2003a, for a discussion). Maps of geographic distribution were made using Google Earth and Quantum GIS Wroclaw softwares.

Institutional abbreviations are as listed in Fricke, Eschmeyer (2016) with the addition of UFRO-I for Coleção Ictiológica of Universidade Federal de Rondônia, Porto Velho.

\section{Results}

\section{Galeocharax Fowler, 1910}

Galeocharax Fowler, 1910: 790 [type species Cynopotamus gulo Cope, 1870: 565, by original designation]. -Géry, VuTân-Tuê, 1963b: 239 [as a synonym of Acestrocephalus, subgenus of Cynopotamus]. -Géry, 1972: 27 [as a synonym of Acestrocephalus, subgenus of Cynopotamus].

Type species. Cynopotamus gulo Cope, 1870, original designation.

Diagnosis. Galeocharax differs from all genera of the Characinae (sensu Mattox, Toledo-Piza, 2012) except Cynopotamus and Acestrocephalus, in the presence of spinoid scales. It can be distinguished from members of the latter two genera by the presence of a lateral bony projection on the nasal ( $v s$. projection absent in Acestrocephalus and Cynopotamus, Fig. 1); by having infraorbital 1 anteriorly elongated, reaching the premaxilla and extending anteriorly beyond the antorbital (vs. infraorbital 1 not as anteriorly elongated falling short of the anterior margin of the antorbital in Acestrocephalus and Cynopotamus, Fig. 2); and by the absence of a bony crest on the medial surface of the ectopterygoid ( $v s$. bony crest present in Acestrocephalus and Cynopotamus, Fig. 3). Galeocharax also differs from Cynopotamus in the presence of 6-13 small conical teeth posterior to the dentary canines ( $v s$. small conical teeth posterior to the dentary canines absent, Fig. 4); and in the lack of a pronounced notch on the posteroventral margin of the cleithrum ( $v s$. notch on posteroventral margin of the cleithrum present, Fig. 5).
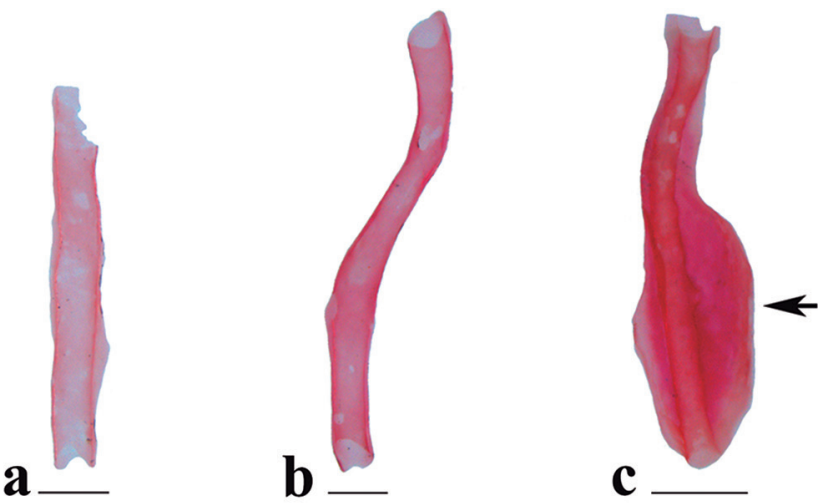

Fig. 1. Nasal bone of a. Cynopotamus xinguano, MZUSP 94196, $97.9 \mathrm{~mm}$ SL, scale bar $500 \mu \mathrm{m}$; b. Acestrocephalus stigmatus, MZUSP 94216, $85.0 \mathrm{~mm} \mathrm{SL}$, scale bar $500 \mu \mathrm{m}$, and c. Galeocharax gulo, MZUSP 62839, $127.2 \mathrm{~mm}$ SL, scale bar $1 \mathrm{~mm}$. Right side, ventral view, anterior tip oriented downwards. Arrow points to lateral bony projection.

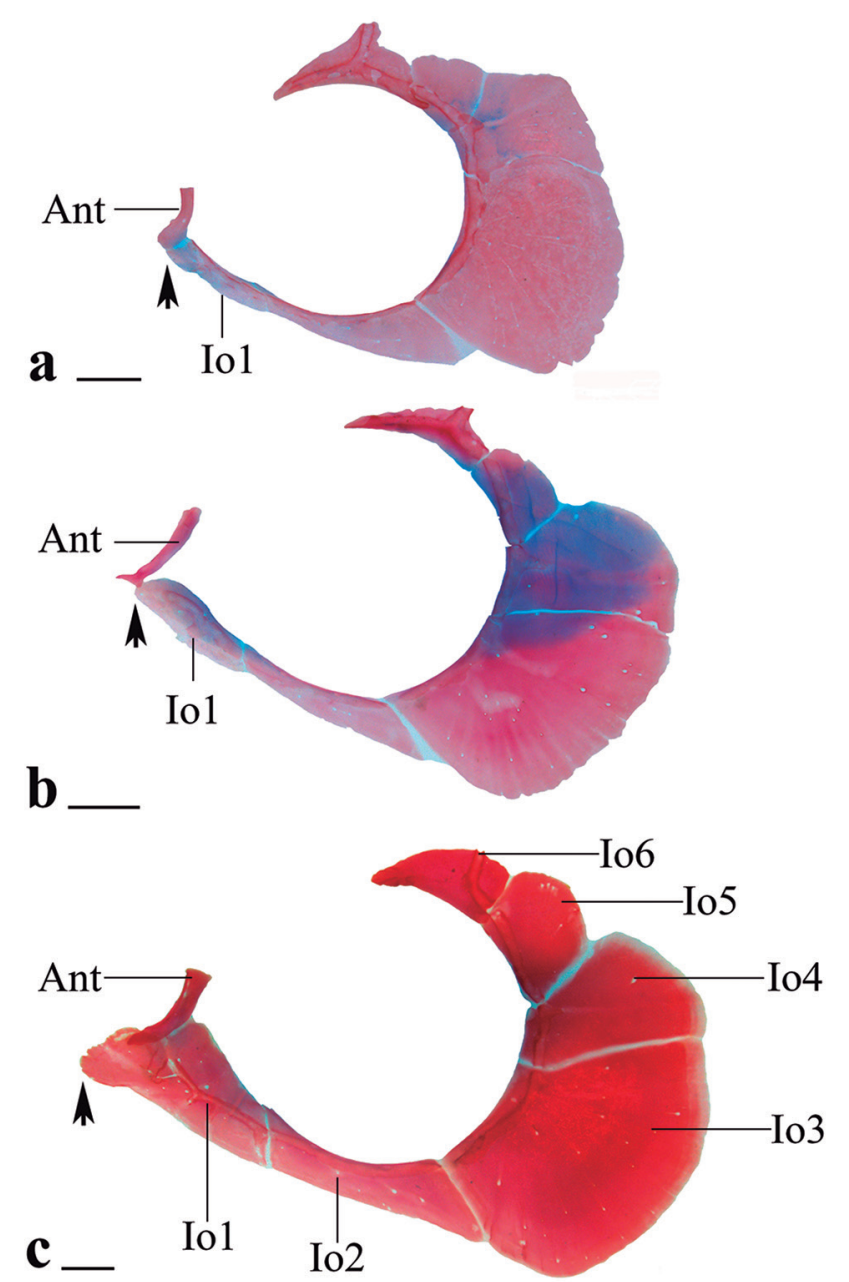

Fig. 2. Infraorbital series of a. Cynopotamus xinguano, MZUSP 94196, $97.9 \mathrm{~mm}$ SL; b. Acestrocephalus stigmatus, MZUSP 94216, $85.0 \mathrm{~mm} \mathrm{SL}$, and c. Galeocharax gulo, MZUSP 62839, $127.2 \mathrm{~mm}$ SL. Left side, lateral view. Black arrows point to anterior tip of infraorbital 1. Ant - antorbital, Io 1-6 - Infraorbital 1-6. Scale bars $2 \mathrm{~mm}$. 

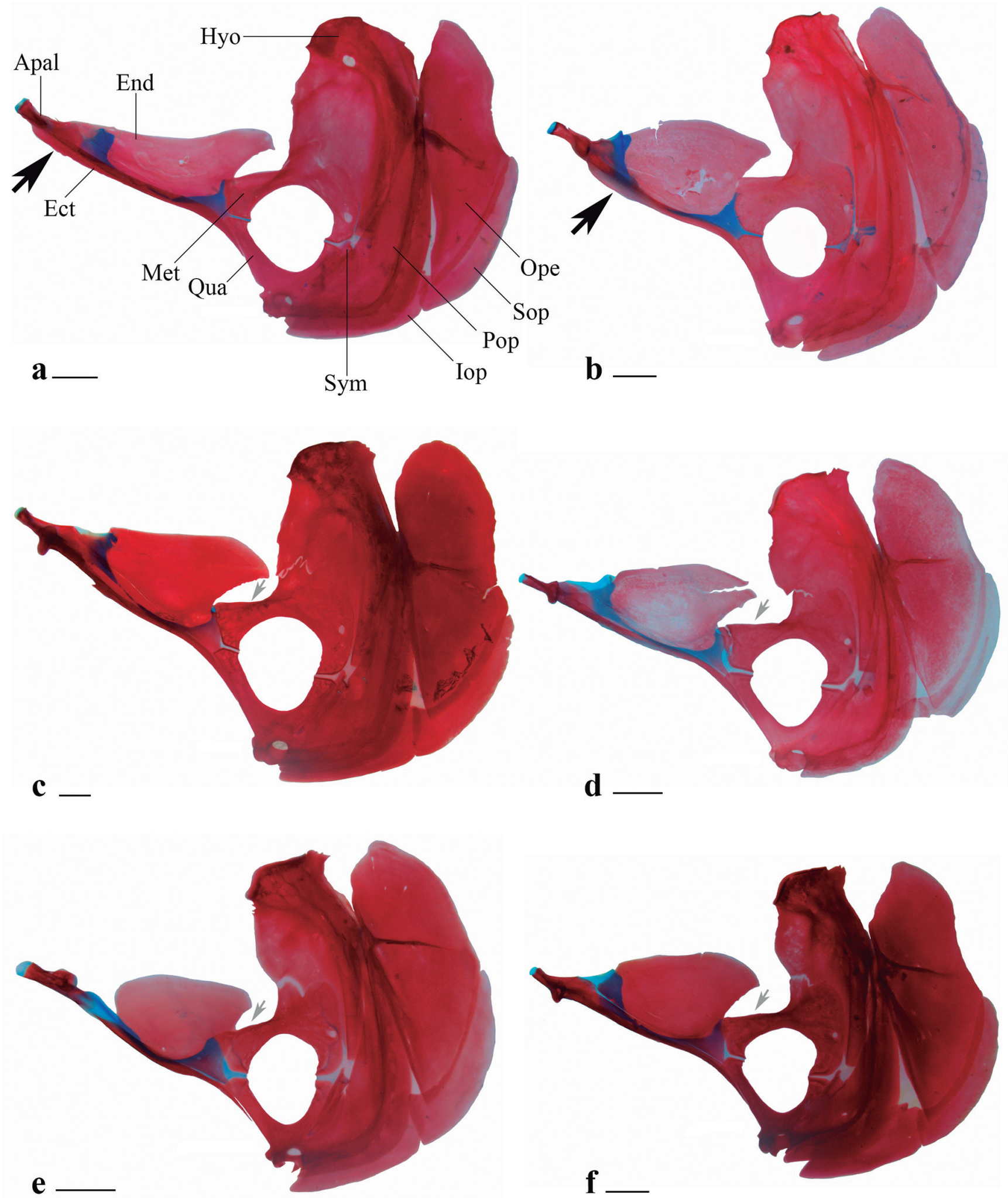

Fig. 3. Hyopalatine arch and opercular series of a. Acestrocephalus stigmatus, MZUSP 94216, $85.0 \mathrm{~mm} \mathrm{SL;} \mathrm{b.} \mathrm{Cynopotamus}$ xinguano, MZUSP 94196, 97.6 mm SL; c. Galeocharax gulo, MZUSP 62839, $127.2 \mathrm{~mm}$ SL; d. Galeocharax goeldii, UFRO-I 5468, 77.9 mm SL; e. Galeocharax humeralis, MZUSP 19984, $66.0 \mathrm{~mm}$ SL; f. Galeocharax gulo, MZUSP $1048088.8 \mathrm{~mm}$ SL. Left side, lateral view. Black arrows point to ectopterygoid crest, gray arrows point to anterior region of metapterygoid. Apal - autopalatine; Ect - ectopterygoid; End - endopterygoid; Hyo - hyomandibular; Iop - interopercle; Met - metapterygoid; Ope - opercle; Pop - preopercle; Qua - quadrate; Sop - subopercle; Sym - symplectic. Scale bars 2 mm. 

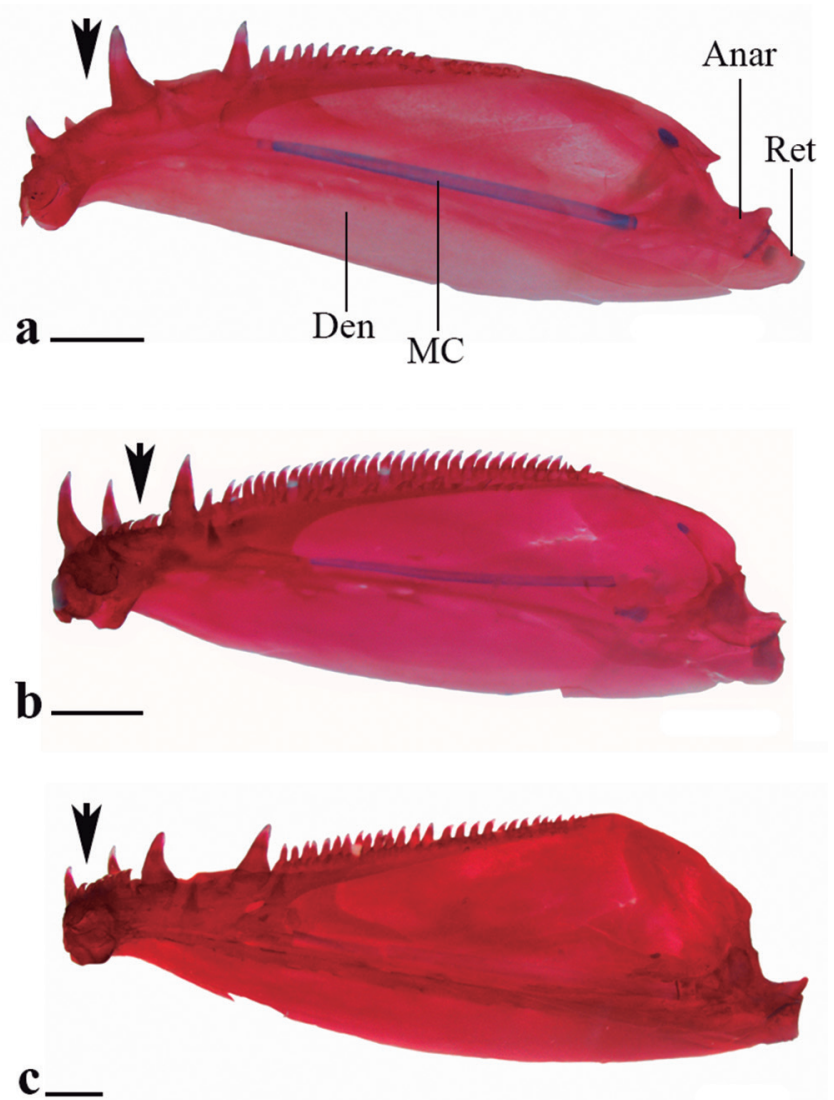

Fig. 4. Lower jaw of a. Cynopotamus xinguano, MZUSP 94196, 97.9 mm SL; b. Acestrocephalus stigmatus, MZUSP 94216, $85.0 \mathrm{~mm}$ SL and c. Galeocharax gulo, MZUSP 62839, $127.2 \mathrm{~mm}$ SL. Right side, medial view. Black arrows points to region posterior to dentary canines. Anar - anguloarticular; MC - Meckel's cartilage; Den - dentary; Ret - retroarticular. Scale bars $2 \mathrm{~mm}$.
Remarks. The nominal species of Galeocharax were all described between 1834 and 1913, but the genus name was proposed only in 1910 (Fowler, 1910). Before the proposal of the genus, the species were allocated in several distinct genera such as Charax Scopoli, Hydrocyon Cuvier (= Hydrocynus Cuvier), Cynopotamus Valenciennes, Xiphorhamphus Müller, Troschel (= Acestrorhynchus Eigenmann, Kennedy), Anacyrtus Günther (= Charax), Eucynopotamus Fowler (= Roeboides Günther) and Cyrtocharax Fowler (= Cynopotamus). The name Galeocharax was proposed in order to resolve a nomenclatural confusion originated by publications of Fowler (1901, 1904, 1910) and Eigenmann (1903, 1907, 1910) that was later detailed by Géry, Vu-Tân-Tuê (1963a). It should be noted that Fowler's proposition was not followed by a discussion about the species included neither presented a diagnosis of Galeocharax. Most of the publications citing Galeocharax, subsequent to the proposition of the genus name consisted of species lists that did not include any discussion or characterization of the genus or the species included.

Menezes (1976) recognized a natural group comprising Cynopotamus, Acestrocephalus and Galeocharax, the Cynopotaminae on the basis of morphological characters and differentiated Galeocharax from Acestrocephalus and Cynopotamus based on the three characters mentioned above in the Diagnosis.

Galeocharax, Acestrocephalus and Cynopotamus have also been considered phylogenetically related in studies subsequent to that of Menezes (1976), however hypotheses of relationships among the three genera differ among authors (Lucena, 1998; Mirande, 2010; and Mattox, ToledoPiza, 2012, based on morphological data, and Oliveira et al., 2011, based on molecular data). Mattox, Toledo-

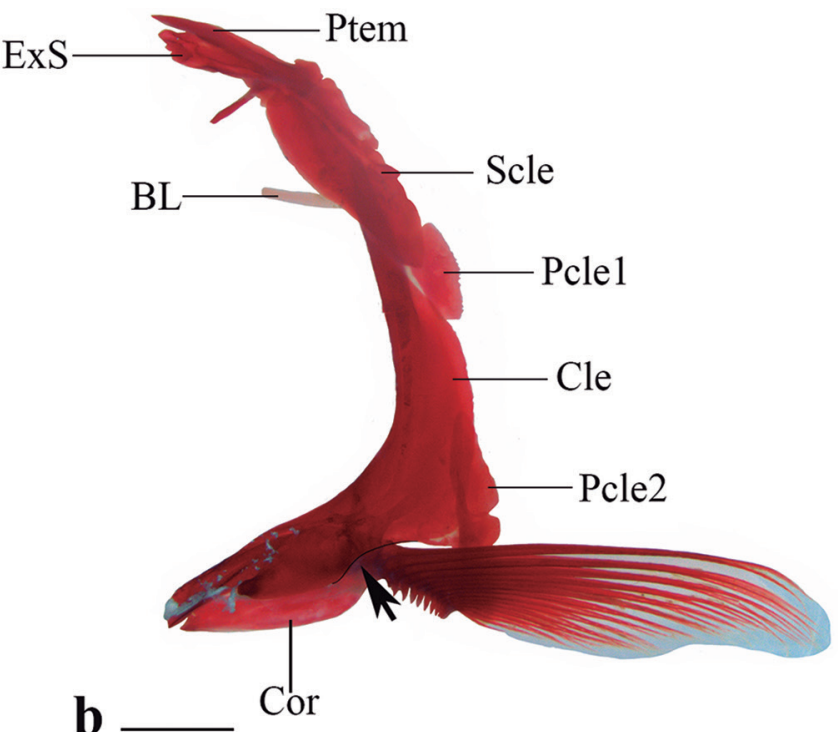

a

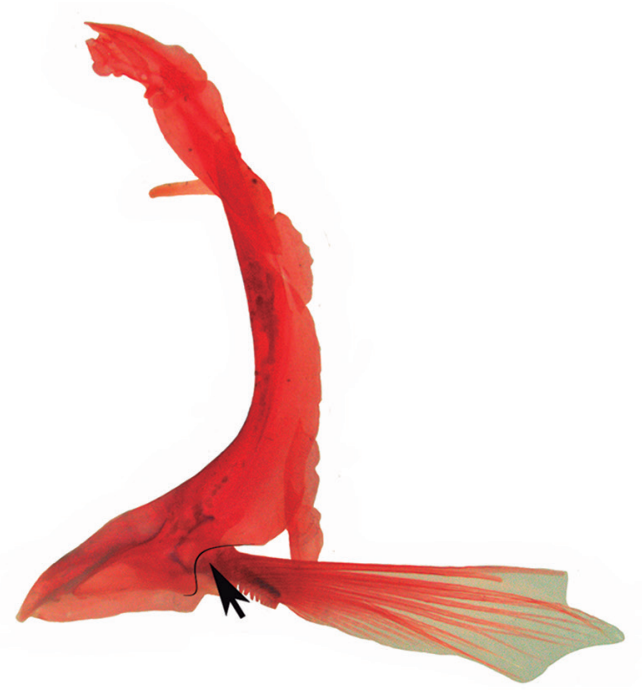

Fig. 5. Pectoral girdle of a. Cynopotamus xinguano, MZUSP 94196, $97.9 \mathrm{~mm} \mathrm{SL}$, scale bar $2 \mathrm{~mm}$ and b. Galeocharax gulo, MZUSP 62839, $127.2 \mathrm{~mm}$ SL scale bar $5 \mathrm{~mm}$. Black arrows point to posteroventral margin of cleithrum. Lateral view of left side. BL - Baudelot's ligament; Cle - cleithrum; Cor - coracoid; ExS - extrascapular; Pcle1-2 - postcleithrum 1-2; Ptem - posttemporal. 
Piza (2012) corroborated the hypothesis of monophyly of Galeocharax and proposed additional synapomorphies for the genus: 1) the presence of scales covering, at least part of the caudal fin lobes on the median region of the fin; 2 ) the ventral portion of the levator arcus palatini muscle extending until the anterior margin of the metapterygoid; and 3 ) the anteroventral margin of the cleithrum with a well developed and anteriorly oriented projection.

\section{Key to the species of Galeocharax}

1. Perforated lateral line scales 77-87...... Galeocharax gulo. Perforated lateral line scales 88-105 2.

2. 1-3 Small conical teeth between the third and fourth dentary canines Galeocharax humeralis.

Small conical teeth between the third and fourth dentary canines absent. Galeocharax goeldii.

\section{Galeocharax goeldii (Fowler, 1913)}

\section{Fig. 6}

Anacyrtus humeralis. -Perugia, 1897:26 [listed; Reyes, río Beni, Bolívia; misidentification].

Charax goeldii Fowler, 1913:568 [original description; type locality: tributary of rio Madeira, near Porto Velho, Brazil]. -Schultz, 1950:62 [synonym of Cyrtocharax amazonum
(Günther) = Cynopotamus amazonum]. -Menezes, 1976:44 [as a synonym of Galeocharax gulo (Cope)]. -Lucena, Menezes, 2003:203 [as a synonym of Galeocharax gulo (Cope)].

Cyrtocharax goeldii. -Fowler, 1950:311 [listed].

Cynopotamus (Acestrocephalus) goeldii. -Géry, Vu-Tân-Tuê, 1963b:240 [diagnosis in key]. -Géry, 1972:25 [description; diagnosis in key]; -Géry, 1977:306 [listed].

Galeocharax gulo. -Barthem et al., 2003:80 [río Madre de Dios basin].

Galeocharax kneri. -Barthem et al., 2003:80 [río Madre de Dios basin]. -Goulding et al., 2003b:143 [río Madre de Dios basin].

Galeocharax goeldii. -Menezes, 2007a:21 [redescription, species removed from synonymy]. -Rapp Py-Daniel, 2007:111 [as Galeocharax sp., rio Madeira basin]. -Lima et al., 2013:253 [listed, rio Madeira basin].

Diagnosis. Galeocharax goeldii differs from $G$. humeralis in the absence of small conical teeth between the third and fourth dentary canines (Fig. 7a) (vs. 1-3 small conical teeth, Fig. 7c), and from G. gulo in the higher number of perforated lateral line scales (88-97 vs. 77-87, Tab. 1). Although there is overlap in the number of scales above and below the lateral line between G. goeldii and G. gulo, the former species shows a tendency towards higher values of scales above (17-20, median 18 vs. 14-19, median 16, in G. gulo, Tab. 2) and below (15-17, median 16 vs. 11-16, median 13 in G. gulo, Tab. 3) the lateral line, respectively.

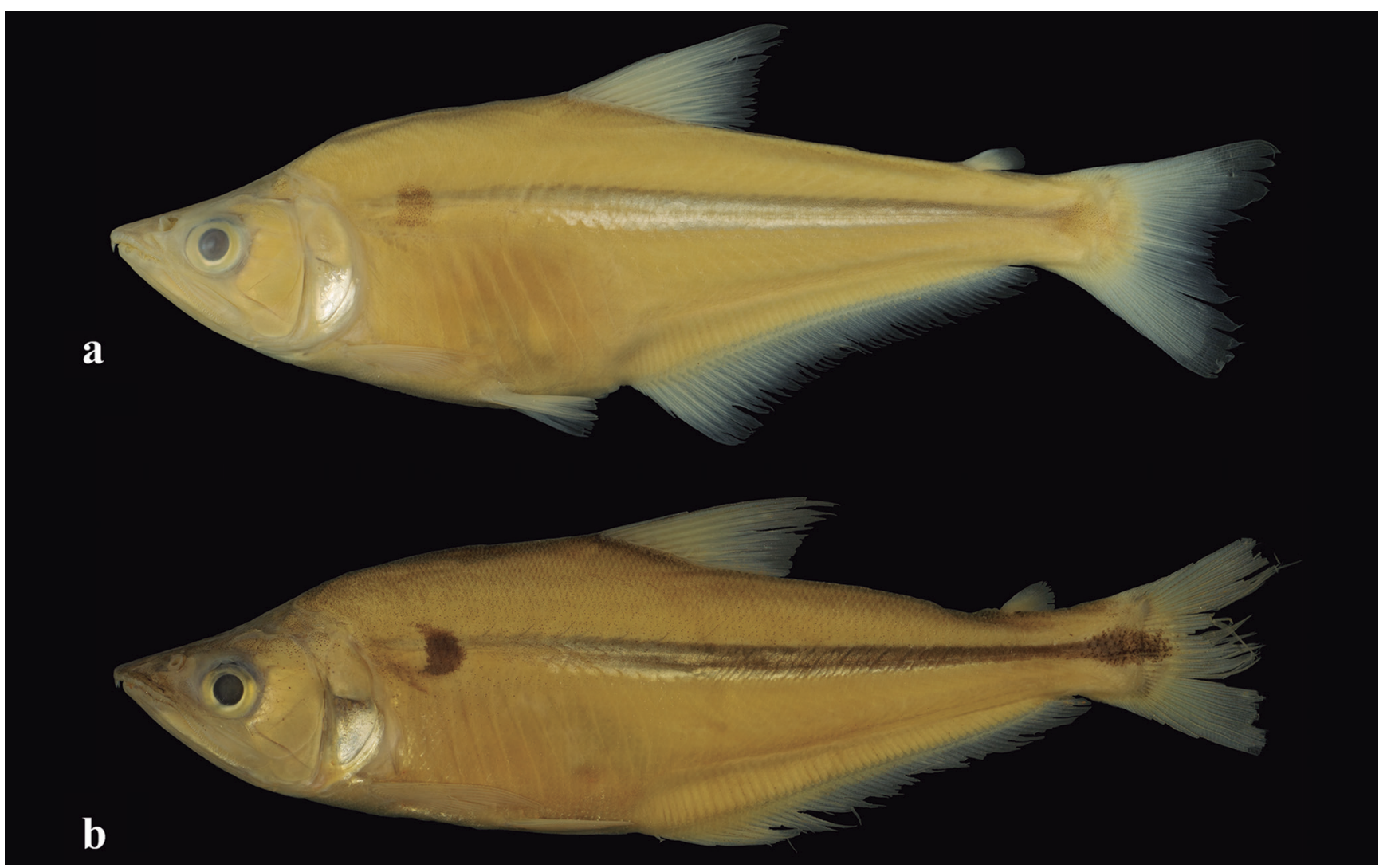

Fig. 6. Galeocharax goeldii a. INPA 24598, $109.7 \mathrm{~mm}$ SL. Brazil, Amazonas rio Madeira basin, Paraná do Uruá, and b. USNM 305367, 129.6 mm SL. Bolivia, Beni, río Beni basin, río Curiraba. 

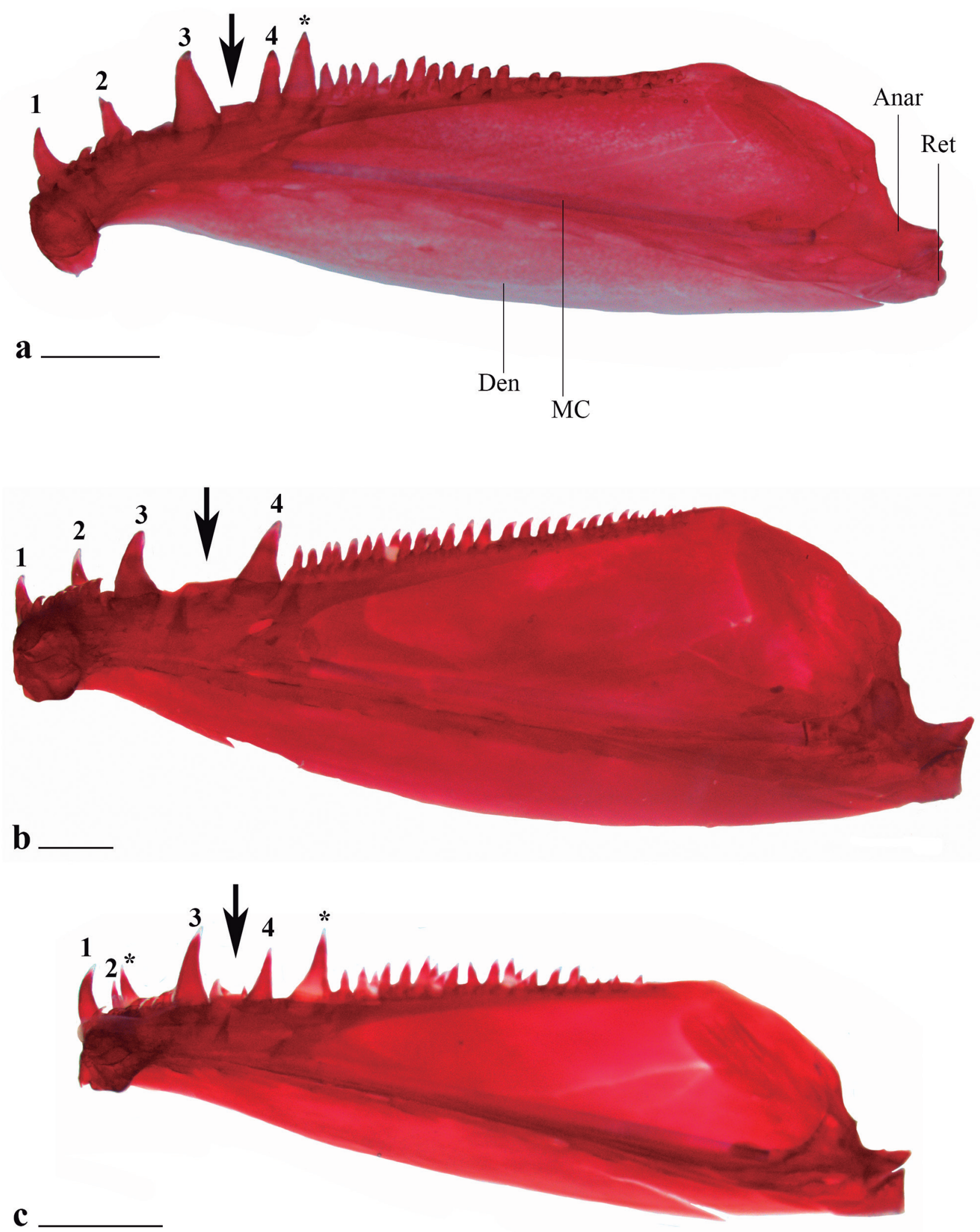

Fig. 7. Lower jaw of a. Galeocharax goeldii, UFRO-I 5468, 77.9 mm; b. G. gulo, MZUSP 62839, $127.2 \mathrm{~mm}$ SL and c. G. humeralis, MZUSP 19984, $66.0 \mathrm{~mm}$ SL. Right side, medial view. Black arrows point to region between third and fourth dentary canine teeth. Numbers 1 to 4 indicate first to fourth canine teeth. * indicates replacement teeth. Anar - anguloarticular; Den - dentary; MC - Meckel's cartilage; Ret - retroarticular. Scale bars $2 \mathrm{~mm}$. 
Tab. 1. Frequency distribution of perforated lateral-line scales of species of Galeocharax.

\begin{tabular}{|c|c|c|c|c|c|c|c|c|c|c|c|c|c|c|c|c|c|c|c|c|c|c|c|c|c|c|c|c|c|c|}
\hline & 77 & 78 & 79 & 80 & 81 & 82 & 83 & 84 & 85 & 86 & 87 & 88 & 89 & 90 & 91 & 92 & 93 & 94 & 95 & 96 & 97 & 98 & 99 & 100 & 101 & 102 & 103 & 104 & 105 & Total \\
\hline G. goeldii & & & & & & & & & & & & 3 & 8 & 14 & 5 & 7 & 11 & 7 & 4 & 4 & 5 & & & & & & & & & 68 \\
\hline G. gulo & 3 & 18 & 52 & 72 & 57 & 70 & 63 & 48 & 23 & 13 & 8 & & & & & & & & & & & & & & & & & & & 427 \\
\hline G. humeralis & & & & & & & & & & & & & & 5 & 8 & 3 & 8 & 12 & 15 & 20 & 12 & 6 & 6 & 7 & 4 & 3 & 1 & 1 & 1 & 112 \\
\hline
\end{tabular}

Tab. 2. Frequency distribution of number of scale rows between the dorsal-fin origin and lateral line of species of Galeocharax.

\begin{tabular}{|c|c|c|c|c|c|c|c|c|}
\hline & 14 & 15 & 16 & 17 & 18 & 19 & 20 & Total \\
\hline G. goeldii & & & & 13 & 20 & 18 & 4 & 55 \\
\hline G. gulo & 12 & 131 & 141 & 83 & 24 & 3 & & 394 \\
\hline G. humeralis & & & & 9 & 46 & 38 & 9 & 102 \\
\hline
\end{tabular}

Tab. 3. Frequency distribution of number of scale rows between the pelvic-fin origin and lateral line of species of Galeocharax.

\begin{tabular}{lcccccccc}
\hline & 11 & 12 & 13 & 14 & 15 & 16 & 17 & Total \\
\hline G. goeldii & & & & & 13 & 30 & 15 & 58 \\
G. gulo & 10 & \multirow{2}{*}{138} & 158 & 54 & 44 & 7 & & 411 \\
G. humeralis & & & & 11 & 55 & 36 & & 102 \\
\hline
\end{tabular}

Description. Morphometric data of Galeocharax goeldii presented on Tab. 4. Largest specimen examined $213.3 \mathrm{~mm}$ SL. Body elongated, laterally compressed and moderately deep, largest body depth at vertical through dorsal-fin origin. Dorsal profile of head slightly concave from tip of snout to posterior tip of supraoccipital spine. Dorsal profile of body slightly convex from posterior tip of supraoccipital spine to base of first dorsal-fin ray, posteroventrally slanted to slightly convex along dorsal-fin base. Dorsal profile from base of last dorsal-fin ray to caudal peduncle straight, slightly concave along caudal peduncle. Ventral profile of head and body convex from tip of lower jaw to anal-fin origin, posterodorsally slanted along anal-fin base, straight to slightly concave along caudal peduncle. Profile of posterior bony margin of opercle slightly concave or straight, rarely convex.

Tab. 4. Morphometric data of species of Galeocharax. SD = standard deviation, Standard length in mm.

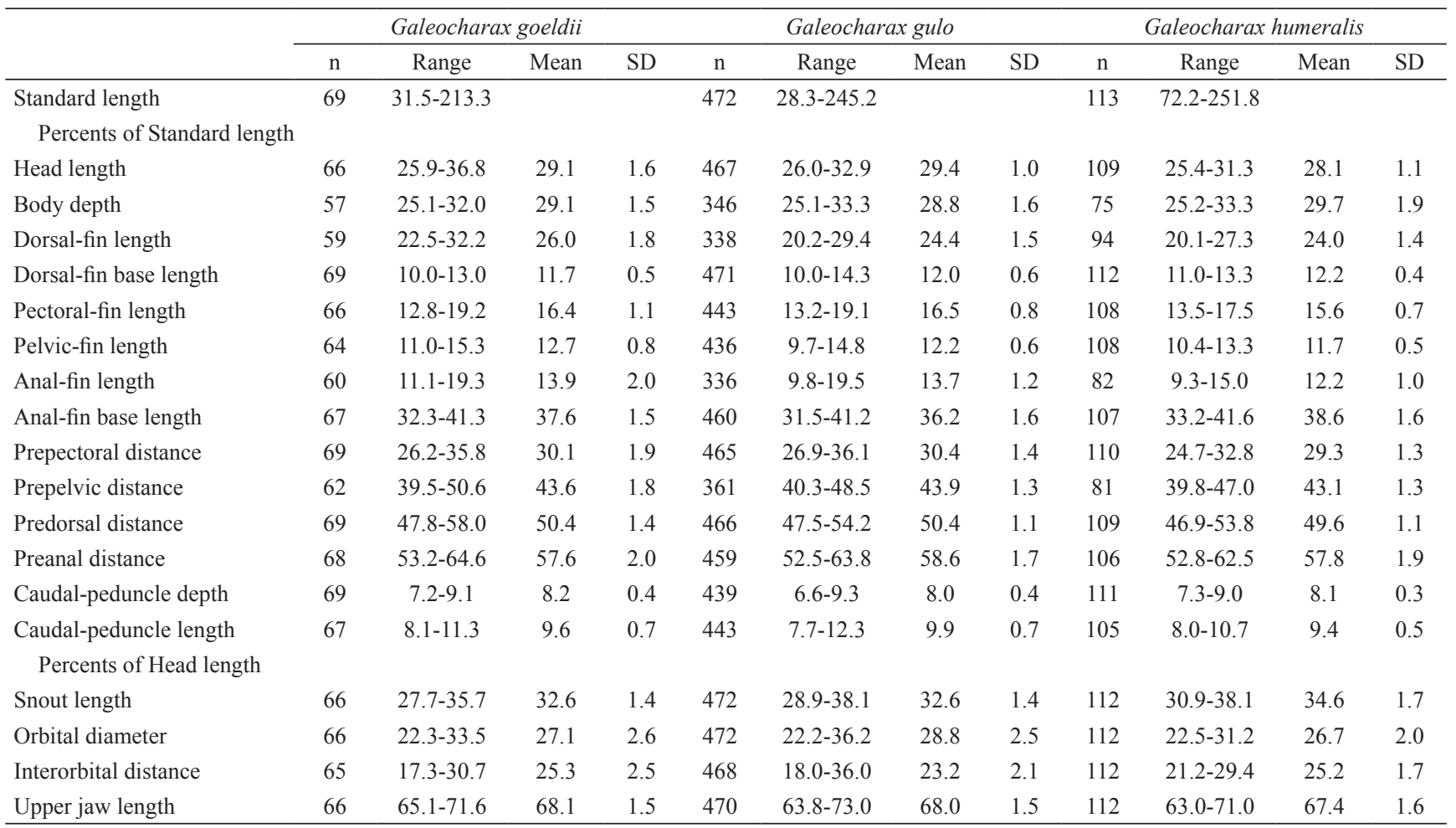

Dorsal-fin origin situated anterior to half of SL, base of last dorsal-fin ray posterior to vertical through analfin origin. Proximal-medial radial of first dorsal-fin pterygiophore inserted posterior to neural spine of ninth vertebra. Dorsal-fin rays ii,9. Profile of distal margin of dorsal fin straight in most specimens. Anal-fin origin situated at approximately half of SL. Proximal-medial radial of first anal-fin pterygiophore situated posterior to haemal spine of $17^{\text {th }}$ vertebra (1). Anal-fin rays iv (1), 40 (8), 41 (12), 42 (16), 43 (23), or 44(8). Anterior lobe of anal fin poorly developed, profile of distal margin of anal fin concave at anterior two thirds; straight to slightly convex 
at posterior third. Pectoral-fin rays i, 13 (1), 14 (28), 15 (31), or $16(10)$; longest ray reaching vertical through pelvic-fin origin when fin is depressed. Profile of posterior margin of pectoral fin almost straight, with four or five proximal rays shorter than others. Specimens of at least $33.7 \mathrm{~mm}$ SL still retain larval rayless pectoral fin. Pelvicfin origin situated anterior to vertical through dorsal-fin origin; pelvic-fin rays i,7; longest ray reaching vertical through anterior border of urogenital opening when fin is depressed, but failing to reach anal-fin origin. Profile of posterior margin of pelvic fin slightly convex, fan-like aspect when extended. Caudal fin forked, principal rays i,9,8,i (1) dorsal procurrent rays 16 (1), ventral procurrent rays 13(1); lower lobe slightly longer and deeper than upper lobe. Adipose fin present, its base anterior to vertical through base of last anal-fin ray.

Spinoid scales (Fig. 8) distributed along entire body, except on region of axilla of paired fins and on region posterior to last ray of dorsal and anal fins where cycloid scales are present. Axillary scale present in pelvic fin. Anal-fin scale sheath with three horizontal scale rows over base of anteriormost anal-fin rays, covering one-fifth of length of anterior fin rays; number of horizontal scale rows gradually decreasing posteriorly to one scale row on posteriormost rays. Base of caudal-fin rays covered by scales.

Mouth terminal, obliquely oriented relative to horizontal body axis. Upper jaw slightly more anteriorly projected than lower jaw. Posterior margin of maxilla extending beyond vertical through posterior margin of orbit. Infraorbitals 1 to 6 present, supraorbital absent, posterior margin of infraorbital 3 not reaching preopercle, posterior margin of infraorbital 4 reaching preopercle in some specimens. Teeth conical. Premaxilla with two teeth rows, inner row with two teeth oriented to interior of mouth, outer row with 8 (4), 9 (28), or 10 (39) teeth, medialmost and lateralmost teeth canines. Maxilla with 38 (8), 39 (10), 40 (12), 41 (12), 42 (8), 43 (4), 44 (6), 45 (2), 46 (3), 47 (2), or 48 (2) conical teeth distributed along entire ventral margin. Dentary with two teeth rows. Inner row with 7 (14), 8 (29), 9 (16), 10 (2), 11 (1), 12 (2), or 13 (2) posteriorly oriented teeth. Outer row with anterior group formed by four canine teeth, third tooth larger, first and fourth usually of similar size, some specimens with fourth tooth intermediate in size between third and first teeth, second tooth always smallest and more external. Space between third and fourth canines occupied by lateral premaxillary canine when mouth is closed. Posterior group of outer teeth with 23 (1) small conical teeth forming row adjacent and continuous to fourth canine.

Lateral line complete. Lateral-line tube present between bases of middle caudal-fin rays. Lateral-line scales 88-97 (68) (Tab. 1), laterosensory canal on each scale with one posteroventral ramification; number of horizontal scale rows between dorsal-fin origin and lateral line 17-20 (55) (Tab. 2); number of horizontal scale rows between lateral line and pelvic-fin origin 15-17 (58) (Tab. 3); number of horizontal scale rows around caudal peduncle 23 (3), 24 (3), 25 (8), 26 (8), 27 (15), or 28 (6).

Total number of vertebrae 41 (11) or 42 (2), abdominal vertebrae 16 (12) or 17 (1), caudal vertebrae 25 (12) or 26 (1). Supraneurals 4 (12) obliquely oriented, proximal tip more anterior than distal tip, anteriormost supraneural lying anterior to neural spine of fifth vertebra, posteriormost lying between neural spines of seventh and eighth vertebrae.

Pseudotympanum present, bordered anteroventraly by obliquus superioris muscle, posteriorly by obliquus superioris muscle and by rib associated with sixth vertebra, posterodorsaly by lateralis superficialis muscle and lateral line nerve. Rib associated with fifth vertebra visible anteriorly, but not bordering muscle hiatus anteriorly (Fig. 9).
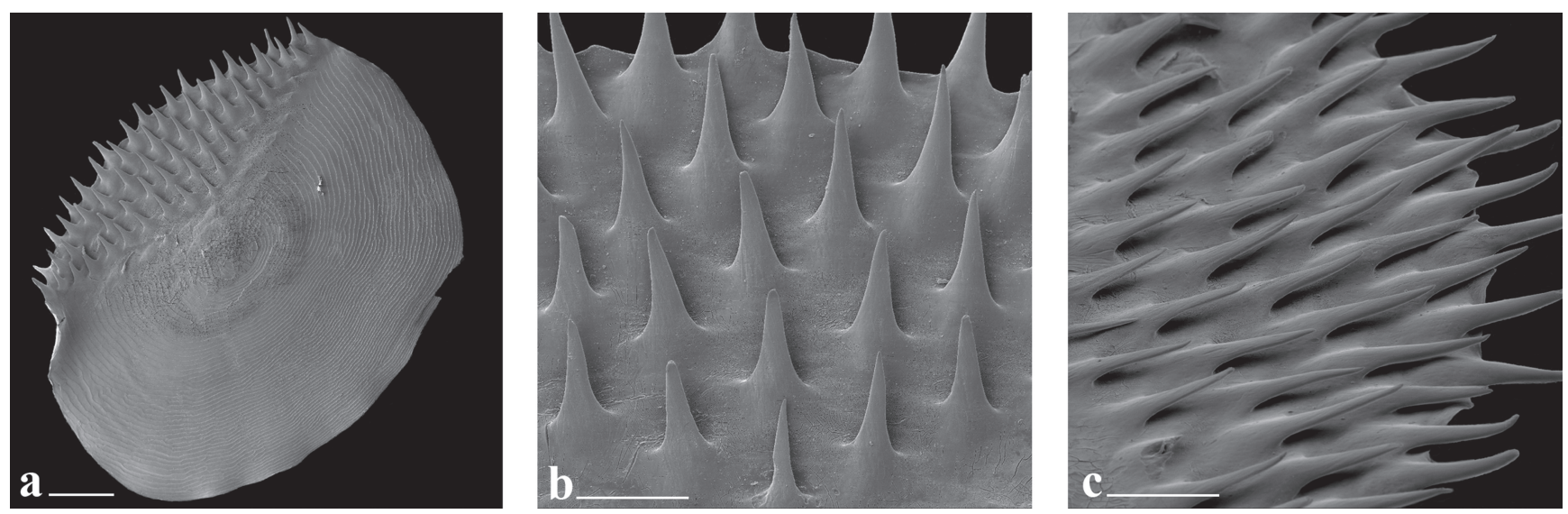

Fig. 8. Scanning electron microscope images of the spinoid scales of Galeocharax goeldii, UFRO-I 9668, 160.8 mm SL. a. dorsal view of scale, posterior margin of scale oriented towards upper left corner, scale bar $500 \mu \mathrm{m}$; b. and c. detail of posterior field of scale, scale bar $200 \mu \mathrm{m}$, in b. dorsal view, posterior margin of scale to top, and c. dorsolateral view, posterior margin of scale to right. 


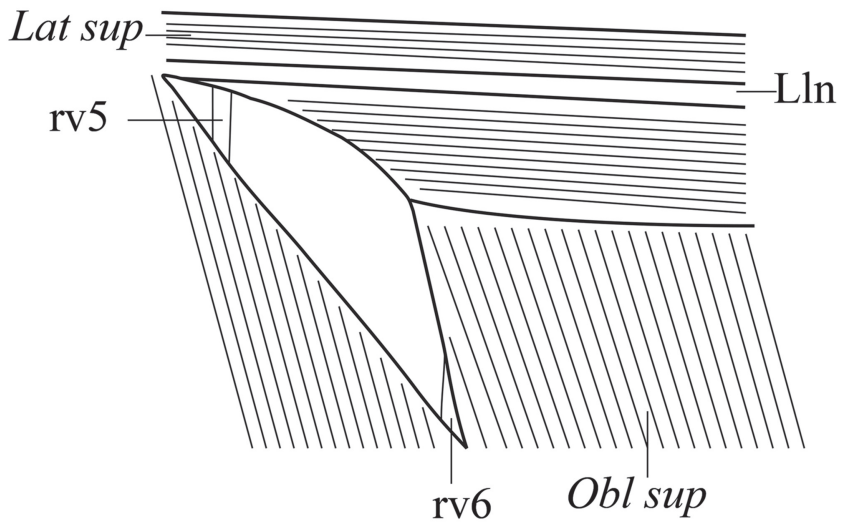

Fig. 9. Schematic drawing of the fibers of muscles that limit the pseudotympanum in Galeocharax. rv5 - rib of vertebra 5; rv6 - rib of vertebra 6; Lat sup - lateralis superficialis muscle; Lln - lateral line nerve; Obl sup - obliquus superioris muscle.

Coloration. Overall body coloration yellowish, dorsal region darker than ventral region due to presence of chromatophores distributed on posterior field of dorsal scales. Dorsal median dark band from supraoccipital spine to dorsal-fin origin, not distinguishable posterior to dorsal fin base.

Dorsal region of head darker until approximately horizontal line through dorsal margin of orbit. Few specimens with scattered chromatophores on infraorbitals, mainly on 4, 5 and 6. Skin bordering mouth more pigmented on premaxilla, maxilla and dentary, mainly on base of canine teeth of lower jaw. Lateral surface of maxilla with sparse chromatophores anteriorly to approximately half of bone length.

Oval shaped blotch on humeral region, largest diameter along vertical axis. Few specimens with crescent shaped humeral blotch with tips of crescent pointed anteriorly (Fig. 6b).

Silvery midlateral longitudinal band on body, dorsal to lateral line, ventral margin of band reaching lateral line in most specimens. Silvery midlateral longitudinal band extending from posterior margin of supracleithrum to posterior margin of hypural plate, narrower at anterior- and posteriormost regions in most specimens, broader at region of vertical through dorsal-fin base. Silvery midlateral longitudinal band widening from caudal peduncle to posterior margin of hypural plate in some specimens, and with ventral margin extending beyond lateral line on region of caudal peduncle.

Dark midlateral longitudinal band dorsal to lateral line extending from humeral region, to approximately half length of median caudal-fin rays, narrower at anterior- and posteriormost regions, broader at region of vertical through dorsal-fin. Some specimens with dark midlateral longitudinal band evident from posterior margin of supracleithrum to median caudal-fin rays. Dark midlateral longitudinal band forming a diamond shaped blotch over caudal peduncle and base of median caudal-fin rays. Dark midlateral longitudinal band not as wide as silvery midlateral longitudinal band except on caudal peduncle region. Dorsal margin of two longitudinal bands usually overlap.
Specimens smaller than $48.0 \mathrm{~mm}$ SL with lines of chromatophores ventral to lateral line, following myosepta on lateral surface of body, region dorsal of anal-fin base and anal-fin rays.

Pectoral and pelvic fins hyaline. Dorsal fin with lines of chromatophores along rays and scattered chromatophores on interradial membrane. Adipose fin pale, weakly pigmented except for line of chromatophores on anterodorsal margin.

Chromatophores forming arched vertical line through base of caudal fin rays; chromatophores more deeply concentrated underneath scales, arched vertical line interrupted in some specimens, with only dorsal and ventral limits evident (Fig. 6b).

Sexual dimorphism. Males of Galeocharax goeldii have bony hooks on pelvic- and anal-fin rays. Bony hooks on anal-fin ray located on lateral surface of posterior branch of branched rays; bony hooks present on last unbranched ray in few specimens. One or two, rarely three hooks per ray segment, hooks dorsoposteriorly oriented (Figs. 10a-c). Bony hooks present on 10 to 23 anteriormost rays. Bony hooks on pelvic fin located on ventral surface of lepidotrichia slightly posteriorly displaced (one specimen with hooks on dorsal surface of fin ray). One or two, rarely three hooks per segment pointing towards base of ray (Fig. 11). Hooks present on four or five lateralmost branched rays.

Geographical distribution. Galeocharax goeldii occurs in the rio Madeira, río Madre de Dios, río Beni, rio Mamoré, and rio Guaporé drainages (Fig. 12).

Remarks. Galeocharax goeldii was originally described as Charax goeldii by Fowler (1913) based on a single specimen, $56.0 \mathrm{~mm} \mathrm{SL}$, collected in a tributary of the rio Madeira, near Porto Velho, RO, Brazil. Later, Menezes (1976) considered the species as a synonym of Galeocharax gulo, based on data presented by Géry (1972), but after examining the holotype of Charax goeldii and additional material from the rio Madeira basin, Menezes (2007a) recognized the species as valid in Galeocharax.

As part of the present study, specimens examined from the río Madre de Dios, río Beni, rio Mamoré, and rio Guaporé drainages showed that $G$. goeldii is more widely distributed within the rio Madeira basin.

Although the holotype of Galeocharax goeldii was not examined during this study, meristic data of the specimen presented by Fowler (1913); Géry (1972) and Menezes (2007a) are summarized on Tab. 5. There are some small differences in the numbers provided by the various authors that could be due to differences in the way of couting, or the condition of the specimen could render the counting difficult. Menezes (2007a) provided the most recent and complete information on the specimen. With the exception of the number of lateral-line sacles ( $87 v s .88-97$ in the present study) and the number of teeth on outer row of premaxilla (12 vs. 8-10 in the present study), data provided by that author are included within the variation observed herein for G. goeldii. 

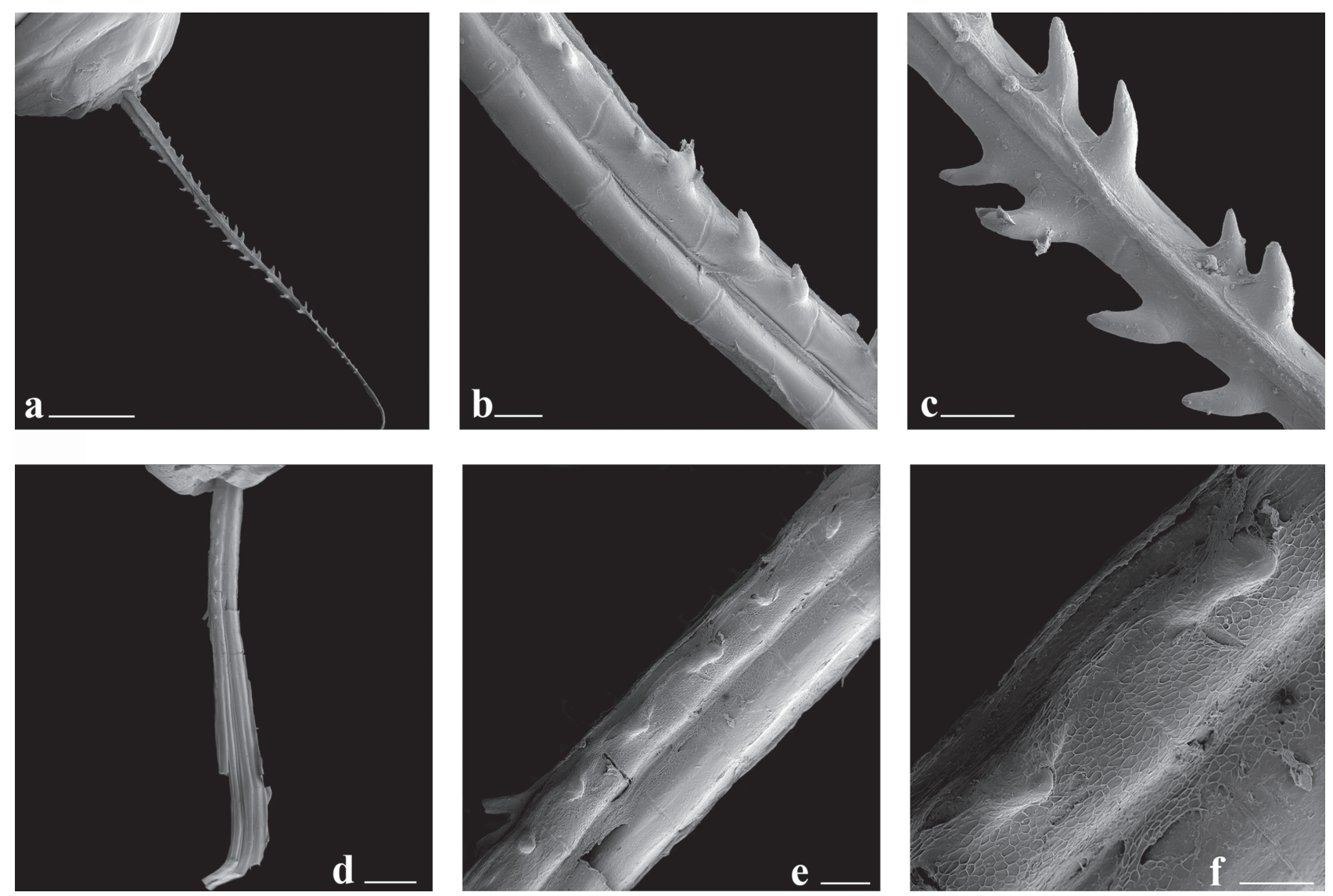

Fig. 10. Scanning electron microscope images of the second branched anal-fin ray of Galeocharax gulo, male, MZUSP 40901, $110.6 \mathrm{~mm}$ SL a.-c. and female, MZUSP 10479, $179.7 \mathrm{~mm}$ SL d.-f.. Proximal tip to upper left corner in a.-c., to top in d. and to upper right corner in e.-f. a. posterior view, scale bar $2 \mathrm{~mm}$; b. Detail of middle portion, lateral view, left side, scale bar 200 $\mu \mathrm{m}$; c. Detail of middle portion, posterior view, scale bar $200 \mu \mathrm{m}$; d. lateral view, right side, scale bar $1 \mathrm{~mm}$; e. Detail of middle portion, lateral view, right side, scale bar $200 \mu \mathrm{m}$, and f. Detail of middle portion, lateral view, right side, scale bar $100 \mu \mathrm{m}$.
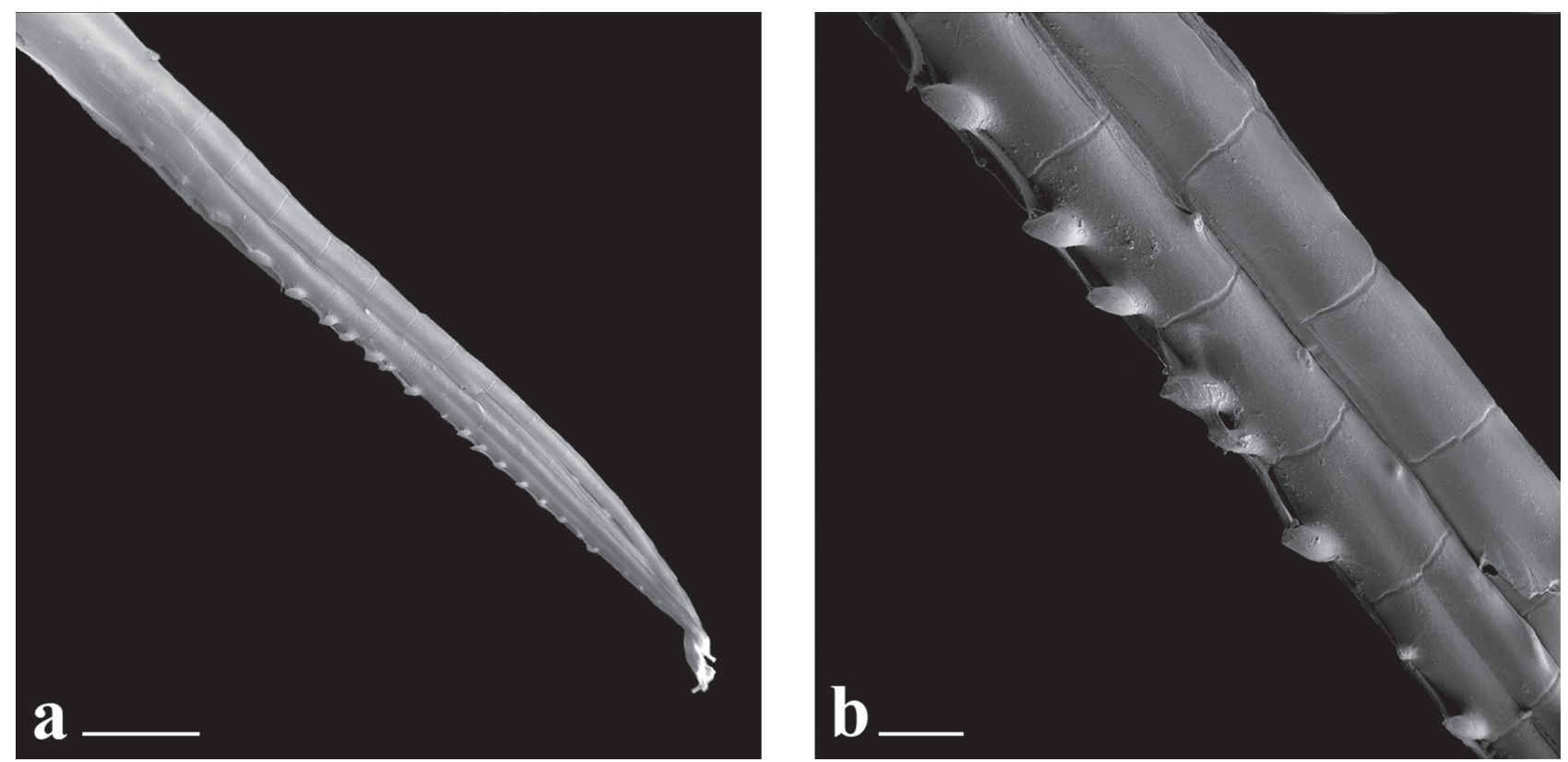

Fig. 11. Scanning electron microscope images of the first branched pelvic-fin ray of Galeocharax gulo, male, MZUSP 40901, $110.6 \mathrm{~mm}$ SL. Proximal tip of ray to upper left corner. a. Ventral view, scale bar $1 \mathrm{~mm}$; b. Detail of middle portion, ventral view, scale bar $200 \mu \mathrm{m}$. 


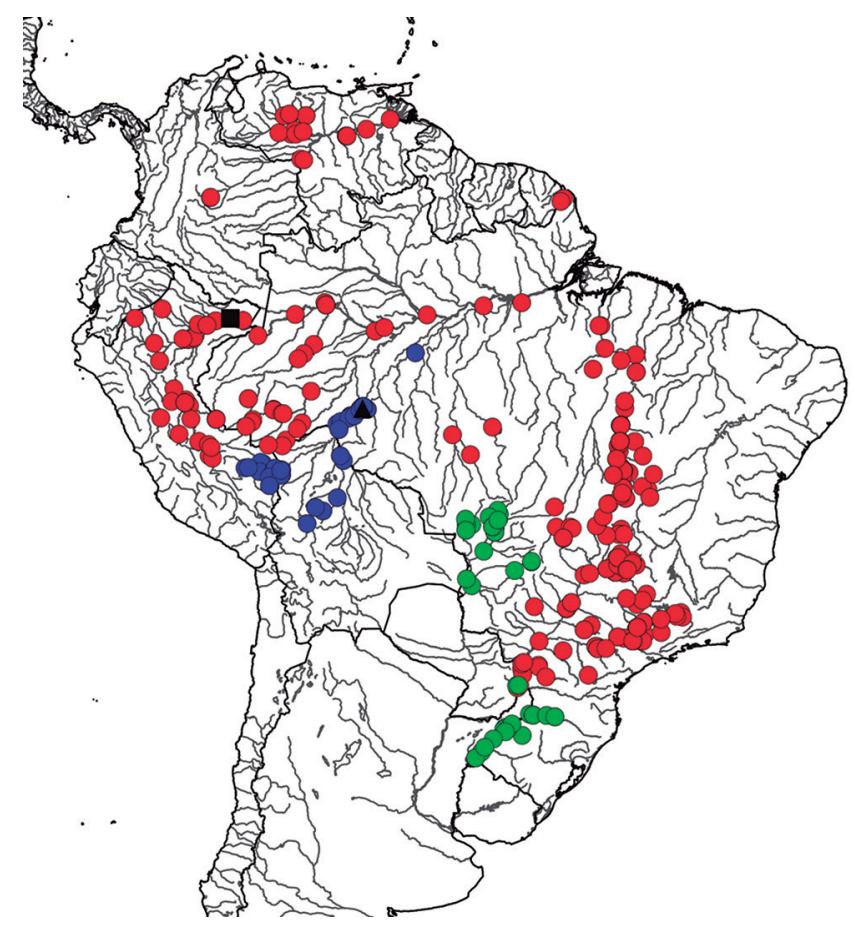

Fig. 12. Map of northern and central South America showing the geographical distribution of species of Galeocharax. G. goeldii (blue circles), the black triangle indicates its type locality, G. gulo (red circles), the black square indicates its type locality, and G. humeralis (green circles).
No variation in meristic and morphometric data associated with any geographic pattern was observed in specimens throughout the distribution range of the species, and the slight discrepancies in those counts of the holotype provided by Menezes (2007a) seem most probably related to the relative poor condition of the specimen associated to its small size.

Material examined. Bolívia: Beni: MNHH 1989-1441, 1, 124.7 mm SL; USNM 301901, 1, 190.0 mm SL; USNM 305364, 1, 173.9 mm SL; USNM 305367, 10, 97.1-213.3 mm SL. La Paz: MZUSP 35951, 1, 144.6 mm. Brazil: Amazonas: INPA 24598, 1 , 109.7 mm SL. Rondônia: INPA 20916, 1, 151.8 mm SL; MZUSP 92432, 5, 20.3-38.6 mm SL; MZUSP 92433, 8, 19.5-48.2 mm SL; MZUSP 92434, 1, 108.0 mm SL; MZUSP 92435, 4, 28.994.6 mm SL; MZUSP 92436, 24, 26.1-89.7 mm SL; UFRO-I 722, 1, 33.5 mm SL; UFRO-I 2246, 1, 54.5 mm SL; UFRO-I 2566, 1, 50.8 mm SL; UFRO-I 5468, 2, 1 c\&s, 77.9-81.2 mm SL; UFRO-I 6854, 1, 121.2 mm SL; UFRO-I 6846, 1, $123.2 \mathrm{~mm} \mathrm{SL;}$ UFRO-I 9705, 1, 120.8 mm SL; UFRO-I 9668, 1, 160.8 mm SL; UFRO-I 12941, 1, 17.3 mm SL; UFRO-I 13077, 2, 96.9-147.5 mm SL; UFRO-I 13090, 2, 101.6-105.7 mm SL; UFRO-I 14233, 2, 150.3-153.0 mm SL; UFRO-I 15986, 1, 59.3 mm SL; UFRO-I 16104, 1, 32.3 mm SL; UFRO-I 17970, 2, 132.5-144.9 mm SL; UFRO-I 19051, 1, $120.1 \mathrm{~mm}$ SL; UFRO-I 19368, 1, $85.2 \mathrm{~mm}$ SL; UFRO-I 20611, 1, 67.9 mm SL; UFRO-I 20612, 1, 68.7 mm SL; UFRO-I 20613, 2, 32.3-49.6 mm SL; UFRO-I 20631, 1, 39.4

Tab. 5. Meristic data of the types of the nominal species of Galeocharax presented by previous authors. A= Valenciennes (1849); B = Géry \& Vu-Tân-Tuê (1963a); C = Cope (1870); D and G = Géry (1972); E = Steindachner (1879); F = Fowler (1913); H = Menezes (2007a).

\begin{tabular}{|c|c|c|c|c|c|c|c|c|}
\hline & \multicolumn{2}{|c|}{ G. humeralis } & \multicolumn{2}{|c|}{ G. gulo } & \multirow{2}{*}{$\begin{array}{c}\text { G. knerii } \\
\text { E }\end{array}$} & \multicolumn{3}{|c|}{ G. goeldii } \\
\hline & A & B & $\mathrm{C}$ & $\mathrm{D}$ & & $\mathrm{F}$ & G & $\mathrm{H}$ \\
\hline Lateral line scales & 115 & $97-98$ & - & $80-83$ & $79-90$ & $81+6$ & 86 & 87 \\
\hline Scale rows between dorsal-fin origin and lateral line & - & 1 & 14 & 14 & $14-18$ & 18 & 17 & 18 \\
\hline Scale rows between lateral line and pelvic-fin origin & - & - & - & - & $13-14$ & 18 & - & - \\
\hline Scale rows between lateral line and anal-fin origin & - & 15 & - & 16 & - & 19 & 16 & 18 \\
\hline Scale rows around caudal peduncle & - & - & - & - & - & - & - & 26 \\
\hline Scale rows on anal-fin sheath & - & - & - & - & - & - & - & - \\
\hline Dorsal-fin rays & 11 & ii,9 & 12 & - & - & ii,9 & - & ii, 9 \\
\hline Pectoral-fin rays & - & $\mathrm{i}, 14-15$ & - & - & - & $\mathrm{i}, 15$ & - & $\mathrm{i}, 15$ \\
\hline Pelvic-fin rays & - & - & - & - & - & $\mathrm{i}, 7$ & - & $\mathrm{i}, 7$ \\
\hline Anal-fin rays & 44 & iv, 41 & 41 & iv, 40 & iv, $40-45$ & iv, $40, i$ & iv, 40 & iv,41 \\
\hline Caudal-fin rays & - & - & - & - & - & - & - & $\mathrm{i}, 9,8, \mathrm{i}$ \\
\hline Teeth on maxilla & - & $43-46$ & - & $31-36$ & - & - & $36-39$ & 40 \\
\hline Teeth on pre-maxilla outer row & - & 10 & 2 (canine) & $9-10$ & 2(canine) & 2(canine) & 9 & 12 \\
\hline Teeth on pre-maxilla inner row & - & 4 & - & 3 & - & - & 2 & 2 \\
\hline Teeth on dentary outer row & - & 4 & 4 & 4 & 4 & 3 (canine) & 5 & 4 \\
\hline Teeth on dentary inner row & - & 9 & - & 8 & - & - & 8 & 7 \\
\hline Teeth on dentary posterior row & - & 23 & - & 22 & - & - & 10 & 18 \\
\hline Abdominal vertebrae & - & - & - & - & - & - & - & - \\
\hline Caudal vertebrae & - & - & - & - & - & - & - & - \\
\hline Total number of vertebrae & - & - & - & - & - & - & - & 42 \\
\hline
\end{tabular}


mm SL; UFRO-I 20632, 3, 21.4-29.5 mm SL; UFRO-I 20633, 2 , 20.5-31.8 mm SL; UFRO-I 20634, 3, 22.8-29.9 mm SL; UFRO-I 20635, 2, 23.1-24.3 mm SL; UFRO-I 20636, 2, 81.3-83.6 mm SL; UFRO-I 20639, 1, 90.9 mm SL. Peru: Madre de Dios: ANSP 143577, 2, 98.3-114.5 mm SL; MUSM 131, 1, 106.9 mm SL; MUSM 4931, 1, 109.4 mm SL; MUSM 7578, 1, $103.3 \mathrm{~mm}$ SL; MUSM 8154, 1, 105.8 mm SL; MUSM 8155, 1, 104.7 mm SL; MUSM 8790, 1, 143.4 mm SL; MUSM 8883, 1, 139.3 mm SL; MUSM 9180, 1, 115.5 mm SL; MUSM 9228, 1, $132.1 \mathrm{~mm}$ SL; MUSM 9564, 1, 125.4 mm SL; MUSM 19413, 1, 115.0 mm SL; MUSM 36890, 1, 106.7 mm SL; MUSM 36918, 2, 105.6-133.0 mm SL; MUSM 36958, 1, 98.7 mm SL.

\section{Galeocharax gulo (Cope, 1870)}

\section{Fig. 13}

Cynopotamus gulo Cope, 1870:565 [original description; type locality Pebas, Peru]. -Eigenmann, Eigenmann, 1891:58 [listed]. -Fowler, 1907:459 [description]. -Fowler, 1940:268 [description, río Ucayali basin]. -Eigenmann, Allen, 1942:259 [listed, río Marañon basin]. -Schultz, 1950:69 [synonym of Cynopotamus molossus Kner (= Roestes molossus)].

Anacyrtus (Cynopotamus) knerii Steindachner, 1879:65 [original description; part, only specimens from Oriçanga; type locality Oriçanga, rio Mogi-Guaçu]. -Schultz, 1950:68 [synonym of Cynopotamus humeralis (Valenciennes) (= Galeocharax humeralis)]. -Aramburu, 1953:299 [synonym of Cynopotamus humeralis (Valenciennes) (= Galeocharax humeralis)]. -Godoy, 1975:235 [as a synonym of Cynopotamus humeralis (Valenciennes) (= Galeocharax humeralis)].

Anacyrtus knerii. -Boulenger, 1887:282 [listed; Canelos, Ecuador, río Pastaza basin]; -Boulenger, 1898:426 [listed; rio Juruá]. -Eigenmann, Eigenmann, 1891:57 [listed; Canelos, Ecuador, río Pastaza basin].

Cynopotamus knerii. -Garman, 1890:13 [listed; Tabatinga, upper rio Paraná basin]. -Eigenmann, Eigenmann, 1891:58 [listed, part, only Iriçanga (= Oriçanga) and Tabatinga, upper rio Paraná basin]. -Eigenmann, Norris, 1900:359 [listed; Piracicaba, São Paulo, upper rio Paraná basin]. -Eigenmann, Allen, 1942:259 [río Itaya, Iquitos, río Amazanas basin]. -Fowler, 1945:158 [listed; distribution: part, only Iquitos, río Amazonas basin]. -Fowler, 1950:309 [listed; distribution: part, except Bolivia and rio Paraguai].

Cynopotamus humeralis. -Kner, 1860:49 [part; only specimens from Oriçanga, upper rio Paraná basin]. -Garman, 1890:13 [listed; part, only specimens from Saô Paulo (São Paulo) and Goyaz (Goiás), upper rio Paraná basin]. -Eigenmann, Eigenmann, 1891:58 [listed; distribution: part, only Sao Paolo (São Paulo) and Goyaz (Goiás), upper rio Paraná basin]. -Godoy, 1975:235 [Mogi Guassu = Mogi Guaçu, upper rio Paraná basin, description].

Anacyrtus humeralis. -Pellegrin, 1899:157 [río Apure, Venezuela]. Eucynopotamus gulo. -Eigenmann, 1907:770 [listed]. -Eigenmann, 1910:445 [listed, Pebas, Peru, río Amazonas basin].
Eucynopotamus knerii. -Eigenmann, 1907:770 [listed]. -Eigenmann, 1910:445 [listed; distribution: part, except from La Plata].

Cynopotamus knerii. -Pellegrin, 1909:150 [listed; Tonnantins (Tocantins)].

Eucynopotamus humeralis. -Eigenmann, 1910:445 [listed; part, Goyaz (Goiás), upper rio Paraná basin]. -La Monte, 1935:8 [listed; rio Purus].

Galeocharax gulo. -Fowler, 1910:790 [listed]. -Fowler, 1950:314 [listed; part, except rio Paraguai]. -Menezes, 1976:43 [synonymy, description, distribution]. -Ortega, Vari, 1986:7 [listed; Peru]. -Lowe-McConnell, 1991:68 [rio das Mortes, rio Araguaia basin]. -Taphorn, 1992:185 [río Apure, Venezuela]. -Silvano et al., 2001:72 [río Juruá]. -Lucena, Menezes, 2003:203 [listed, distribution]. -Santos et al., 2004:57 [diagnosis, lower rio Tocantins]. -Lasso et al., 2004:120 [Ventuari, Meta, Arauca, río Apure and río Orinoco]. -Mojica et al., 2005:199 [río Amazonas, Letícia, Colombia]. -Bogotá-Gregory, MaldonadoOcampo, 2006:72 [río Amazonas, Colombia]. -Galvis et al., 2006:201 [Letícia, Colombia, río Amazonas basin]. -Ortega et al., 2006:104 [río Putumayo, Peru]. -Buckup et al., 2007: 35 [listed, distribution]. -Menezes, 2007a:24 [correction of erroneous locality record for rio São Francisco]. -MaldonadoOcampo et al., 2008:178 [río Amazonas basin, Colombia]. -Pelicice et al., 2009:35 [environment impact of river dams, rio Tocantins basin]. -Freitas et al., 2009:47 [reservoir ecology rio Tocantins basin]. -Neuberger et al., 2009:61 [reproductive activity in reservoir rio Tocantins basin]. -Monteiro et al., 2009:82 [diet variation in reservoir rio Tocantins basin]. -Mérona et al., 2010:196 [listed, lower rio Tocantins basin]. -Ortega et al., 2012:36 [listed, Peru, río Amazonas basin].

Galeocharax knerii. -Fowler, 1910:790 [listed]. -Menezes, 1976:45 [synonymy, restriction of type locality to Oriçanga, rio Mogi-Guaçu, São Paulo, description, distribution]. -Lucena, Menezes, 2003:203 [listed, distribution]. -Milko et al., 2003:43 [rio Paranapanema basin]. -Júlio Jr. et al., 2003:79 [listed, upper rio Paraná flood plains]. -Magalhães et al., 2004 [reproduction in reservoir, upper rio Paraná basin]. -Petry et al., 2003:5 [listed, upper rio Paraná flood plains]. -Gomiero, Braga, 2006:58 [rio Corumbataí basin]. -Shibatta, Dias, 2006:57 [listed]. -Buckup et al., 2007:35 [listed, distribution]. -Graça, Pavanelli, 2007:90 [upper rio Paraná flood plains]. -Langeani et al., 2007:184 [listed, upper rio Paraná basin]. -Geahl, 2007:153 [rio Tibagi, upper rio Paraná basin]. -Apone et al., 2008:102 [rio Quilombo, upper rio Paraná basin]. -Brandão et al., 2009:454 [parasites; rio Paranapanema, upper rio Paraná basin]. -Zeinad, Prado, 2012:130 [sport fishing, distribution: part, except rio Paraguai]. -Gandini et al., 2012:58 [feeding habits, rio Grande]. -Langeani, Rêgo, 2014:90 [rio Araguari basin].

Eucynopstamus gulo. -Pearson, 1937:92 [Tingo de Pauca, Peru, río Marañon basin].

Cynopotamus (Acestrocephalus) gulo. -Géry, Vu-Tân-Tuê, 1963b:240 [diagnosis in key]. -Géry, 1972:29 [diagnosis in key]. -Géry, Vu-Tân-Tuê, 1977:306 [listed].

Cynopotamus (Acestrocephalus) knerii. -Géry, Vu-Tân-Tuê, 1963b:240 [as a synonym of Cynopotamus humeralis 
(Valenciennes)]. -Géry, 1972:29 [as a synonym of Cynopotamus humeralis (Valenciennes)]. - Géry, 1977:306 [listed].

Galeocharax aff. gulo. -Planquette et al., 1996:193, 220 [identification key; rio Oyapock basin, French Guiana]. -Le Bail et al., 2012:300 [rio Oyapock basin; French Guiana].

Galeocharax kneri. -Vaz et al., 2000:70 [listed, rio Grande basin].
Diagnosis. Galeocharax gulo differs from its congeners in having fewer perforated lateral line scales (77-87 vs. 90-105 in G. humeralis and 88-97 in G. goeldii, Tab. 1). Galeocharax gulo further differs from $G$. humeralis in the absence of small conical teeth between the third and fourth dentary canines (Fig. 7b) (vs. 1-3 small conical teeth, Fig. 7c).

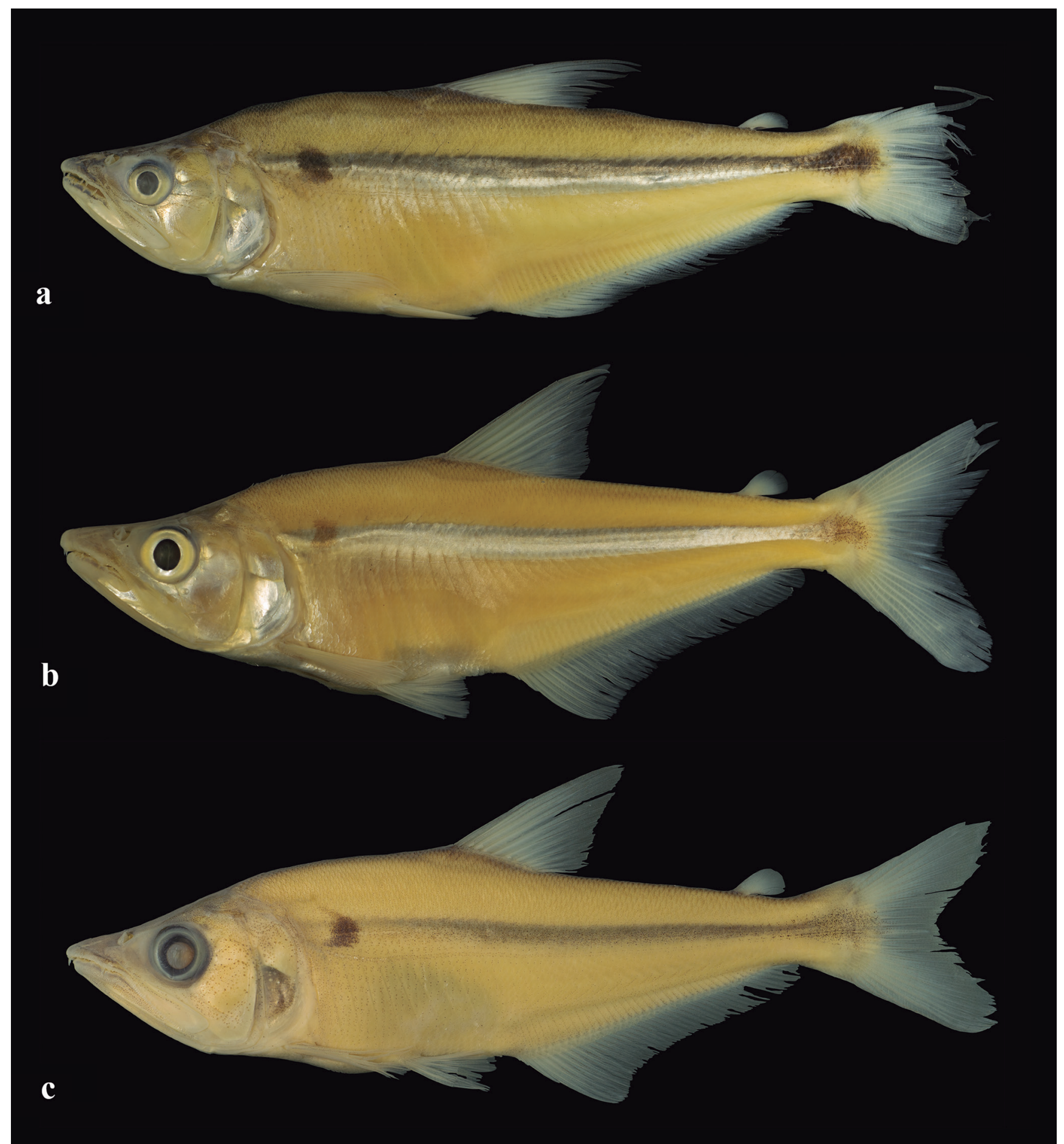

Fig. 13. Galeocharax gulo. a. MZUSP 110473, 148.2 mm SL. Peru, Huánuco, río Ucayali basin, río Huallaga; b. UNT 2689, 88.3 mm SL. Brazil, Tocantins, rio Tocantins basin, rio Maranhão, and c. MZUSP 10558-83, 119.1 mm SL. Brasil, São Paulo, upper rio Paraná basin, rio Pardo. 
Although there is overlap in the number of scales above and below the lateral line between G. gulo and its congeners, G. gulo shows a tendency towards lower values of number of scales above (14-19, median $16 \mathrm{vs}$. 17-20, median 18 in G. humeralis and G. goeldii, Tab. 2) and below (11-16, median 13 vs. 14-16, median 15 in $G$. humeralis and 15-17, median 16 in G. goeldii, Tab. 3) the lateral line, respectively.

Description. Morphometric data of Galeocharax gulo presented on Tab. 4. Largest specimen examined 245.2 $\mathrm{mm}$ SL. Body elongated, laterally compressed and moderately deep, largest body depth at vertical through dorsal-fin origin. Dorsal profile of head slightly concave from tip of snout to posterior tip of supraoccipital spine. Dorsal profile of body slightly convex from posterior tip of supraoccipital spine to base of first dorsal-fin ray, posteroventraly slanted to slightly convex along dorsalfin base. Dorsal profile from base of last dorsal-fin ray to caudal peduncle straight, slightly concave along caudal peduncle. Ventral profile of head and body convex from tip of lower jaw to anal-fin origin, posterodorsaly slanted along anal-fin base, straight to slightly concave along caudal peduncle. Profile of posterior bony margin of opercle usually concave, rarely straight or convex.

Dorsal-fin origin situated anterior to half of SL, base of last dorsal-fin ray posterior to vertical through anal-fin origin. Proximal medial radial of first dorsalfin pterygiophore inserted posterior to neural spine of ninth vertebra. Dorsal-fin rays ii (466) or iii (3), 8 (2), 9 (459), 10 (7), or 11 (1). Profile of distal margin of dorsal fin slightly concave on most specimens. Anal-fin origin situated at approximately half of SL, proximal medial radial of first anal-fin pterygiophore situated posterior to haemal spine of $17^{\text {th }}(4)$ or $18^{\text {th }}(4)$ vertebra. Anal-fin rays v (5), 33 (2), 34 (5), 35 (21), 36 (31), 37 (64), 38 (42), 39 (76), 40 (63), 41 (77), 42 (38), 43 (20), 44 (3), 45 (1), or 46 (1). Anterior lobe of anal fin poorly developed, profile of distal margin of anal fin concave at anterior two thirds; slightly convex at posterior third. Pectoral-fin rays i, 13 (7), 14 (164), 15 (232), 16 (62), or 17 (1); longest ray reaching pelvic-fin origin when fin is depressed. Profile of posterior margin of pectoral fin straight, four or five proximal rays shorter than others. Specimens of at least $34.0 \mathrm{~mm}$ SL still retain larval rayless pectoral fin. Pelvicfin origin situated anterior to dorsal-fin origin; pelvicfin rays i,7; longest ray failing to reach anterior border of urogenital opening when fin is depressed in most examined specimens, not reaching anal-fin origin. Profile of posterior margin of pelvic fin slightly convex, fan-like aspect when extended. Caudal fin forked, principal rays i,9,8,i (5), dorsal procurrent rays 14 (2), 15 (1), or 16 (2), ventral procurrent rays 12 (1) or 13 (4); lower lobe longer and deeper than upper lobe. Adipose fin present, base situated anterior to vertical through base of last anal-fin ray.
Spinoid scales (Fig. 8) distributed along entire body, except on region of axilla of paired fins and region posterior to last ray of dorsal and anal fins where cycloid scales are present. Axillary scale present in pelvic fin. Anal-fin scale sheath with three, generaly two horizontal scale rows over base of anteriormost anal-fin rays, covering onefifth of length of anterior fin rays; number of horizontal scale rows gradually decreasing posteriorly to one or no scale row over posteriormost rays. Base of caudal-fin rays covered by scales.

Mouth terminal, obliquely oriented relative to horizontal body axis. Upper jaw slightly more anteriorly projected than lower jaw. Posterior margin of maxilla generally not surpassing vertical through posterior margin of orbit. Infraorbitals 1 to 6 present, supraorbital absent, posterior margin of infraorbital 3 generally not reaching preopercle, posterior margin of infraorbital 4 not reaching preopercle in most examined specimens. Teeth conical. Premaxilla with two teeth rows, inner row with two teeth oriented to interior of mouth, outer row with 7 (1), 8 (43), 9 (180), 10 (201), or 11 (18) teeth, medialmost and lateralmost teeth canine. Maxilla with 35 (3), 36 (4), 37 (6), 38 (8), 39 (8), 40 (14), 41 (28), 42 (34), 43 (30), 44 (50), 45 (50), 46 (52), 47 (40), 48 (33), 49 (31), 50 (17), 51 (25), 52 (12), 53 (9), 54 (7), or 55 (1) conical teeth distributed along entire ventral margin. Dentary with two teeth rows. Inner row with 6 (2), 7 (110), 8 (219), 9 (58), or 10 (10) posteriorly oriented teeth. Outer row with anterior group formed by four canine teeth, third larger, first and fourth usually of similar size, some specimens with fourth tooth intermediate in size between third and first teeth, second tooth always smallest and more external. Space between third and fourth canines occupied by lateral premaxillary canine when mouth is closed. Posterior group of outer row with 21 (2), 23 (2), 24 (1), 25 (3), 26 (7), 27 (11), 28 (10), 29 (5), 30 (7), 31 (4), 32 (2), 33 (5), or 34 (1) small conical teeth forming row adjacent and continuous to fourth canine.

Lateral line complete. Lateral-line tube present between bases of middle caudal-fin rays. Lateral line scales 77-87 (427) (Tab. 1), laterosensory canal on each scale with one posteroventral ramification; number of horizontal scale rows between dorsal-fin origin and lateral line 14-19 (394) (Tab. 2); number of horizontal scale rows between lateral line and pelvic-fin origin 11-16 (411) (Tab. 3); number of horizontal scale rows around the caudal peduncle 19 (7), 20 (32), 21 (48), 22 (77), 23 (81), 24 (41), 25 (14), or 26 (5).

Total number of vertebrae 39 (2), 40 (32), 41 (79), or 42 (11) abdominal vertebrae 16 (91) or 17 (33), caudal vertebrae 23 (3), 24 (62), 25 (50), or 26(9). Supraneurals 4 (80) or 5 (7) obliquely oriented, proximal tip more anterior than distal tip, anteriormost supraneural lying anterior to neural spine of fifth vertebra, posteriormost lying between neural spines of seventh and eighth vertebrae. Fifth supraneural, whenever present, lying anterior to neural spine of ninth vertebra, vertically oriented. 
Pseudotympanum present, bordered anteroventraly by obliquus superioris muscle, posteriorly by obliquus superioris muscle and by rib associated with sixth vertebra, posterodorsaly by lateralis superficialis and by lateral line nerve. Rib associated with fifth vertebra visible anteriorly, but not bordering the muscle hiatus anteriorly (Fig. 9).

Coloration. Overall body coloration yellowish, dorsal region darker than ventral region due to presence of chromatophores distributed on posterior field of dorsal scales. Dorsal median dark band from supraoccipital spine to dorsal-fin origin on most specimens, not distinguishable posterior to dorsal-fin base.

Dorsal region of head darker until approximately horizontal line through dorsal margin of orbit. Few specimens with scattered chromatophores on infraorbitals, mainly on 4, 5 and 6 . Skin bordering mouth more pigmented on premaxilla, maxilla, and dentary, mainly on base of canine teeth of lower jaw. Lateral surface of maxilla with sparse chromatophores anteriorly to, approximately half of bone length.

Oval shaped blotch on humeral region, largest diameter along vertical axis. A few specimens with crescent shaped humeral blotch with tips of crescent pointed anteriorly (Fig. 13c).

Silvery midlateral longitudinal band on body, dorsal to lateral line, ventral margin of band reaching lateral line in most specimens. Silvery midlateral longitudinal band extending from posterior margin of supracleithrum to posterior margin of hypural plate, narrower at anterior- and posteriormost regions in most specimens, broader at region of vertical through dorsal-fin base. Silvery midlateral longitudinal band widening from caudal peduncle to posterior margin of hypural plate in some specimens, and with ventral margin extending beyond lateral line on region of caudal peduncle.

Dark midlateral longitudinal band dorsal to lateral line extending from posterior margin of supracleithrum to approximately half length of median caudal-fin rays, narrower at anterior- and posteriormost regions, broader at region of vertical through dorsal-fin base. Dark midlateral longitudinal band forming a diamond shaped blotch over caudal peduncle and base of median caudal-fin rays. Dark midlateral longitudinal band not as wide as silvery midlateral longitudinal band except on caudal peduncle region. Dorsal margin of two longitudinal bands usually overlap.

Specimens smaller than $104.0 \mathrm{~mm}$ SL with lines of chromatophores ventral to lateral line, following myosepta on lateral surface of body, region dorsal of anal-fin base and anal-fin rays.

Pectoral and pelvic fins hyaline. Dorsal fin with lines of chromatophores along rays and scattered chromatophores on interradial membrane. Adipose fin pale.

Chromatophores forming arched vertical line through base of caudal-fin rays; chromatophores more deeply concentrated underneath scales; arched vertical line interrupted in some specimens, with only dorsal and ventral limits evident (Fig. 13c).

Sexual dimorphism. Males of Galeocharax gulo have bony hooks on pelvic- and anal-fin rays. Bony hooks on anal-fin rays located on lateral surface of posterior branch of branched rays; bony hooks present on last unbranched rays in a few specimens. One or two, rarely three hooks per ray segment, hooks dorsoposteriorly oriented (Figs. 10a-c). Bony hooks present on 8 to 28 anteriormost rays. Bony hooks on pelvic fin located on ventral surface of lepidotrichia slightly posteriorly displaced. One or two, rarely three hooks per segment pointing towards base of ray (Fig. 11). Hooks present on one to five lateralmost rays.

Eight relatively large sized females (e.g., MZUSP $10479,179,0 \mathrm{~mm} \mathrm{SL}$ ) also have bony hooks on anal fin, however less developed, fewer in number and distributed on fewer rays compared to males (Figs. 10d-f).

Geographical distribution. Galeocharax gulo is widely distributed in the Amazon basin including most of its tributaries except the rio Negro and rio Xingu. It also occurs in the río Orinoco, rio Oyapok, rio Araguaia, rio Tocantins, and the upper rio Paraná basins (Fig. 12).

Geographic variation. Although there is overlap in the range of variation of all meristic and morphometric characters (Tabs. 6-7) throughout the geographic distribution of the species, specimens from the upper rio Paraná and the rio Tocantins basins are more similar to each other, than they are to specimens from the rio Amazonas (excluding specimens from the rio Tapajós basin) and the río Orinoco basins, regarding mainly the number of scales above the lateral line (Tab. 8), number of scales below the lateral line (Tab. 9) and number of maxillary teeth (Tab. 10).

Specimens from the upper rio Paraná basin show lower values of interorbital distance compared to specimens from the rio Amazonas basin (Fig. 14). However, when specimens from other drainages are included in the comparison (rio Tocantins and rio Orinoco basis) such difference becomes less evident (Fig. 15). Similarly, specimens from the rio Tocantins basin show higher values of orbital diameter compared to specimens from the rio Amazonas basin (Fig. 16). However, when specimens from the upper rio Paraná and río Orinoco basins are included in the comparison, their values are intermediate between those from specimens from the rio Tocantins and rio Amazonas basins (Fig. 17).

Specimens from the rio Tocantins basin show a tendency toward lower values in the number of branched anal-fin rays (Tab. 11) and total number of vertebrae (Tab. 12) when compared to specimens from the remainder of the geographic distribution of the species. About $60 \%$ of the examined specimens from the upper rio Paraná basin have 17 abdominal vertebrae $(\mathrm{n}=33)$, while all specimens from the rest of the area of distribution of the species have 16 abdominal vertebrae $(\mathrm{n}=91)$. 
Tab. 6. Morphometric data of specimens of Galeocharax gulo from rio Amazonas, upper rio Paraná and rio Tocantins basins. $\mathrm{SD}=$ standard deviation. Standard length in $\mathrm{mm}$.

\begin{tabular}{|c|c|c|c|c|c|c|c|c|c|c|c|c|}
\hline \multicolumn{13}{|c|}{ Galeocharax gulo } \\
\hline & \multicolumn{4}{|c|}{ Amazonas } & \multicolumn{4}{|c|}{ Upper Paraná } & \multicolumn{4}{|c|}{ Tocantins } \\
\hline & $\mathrm{n}$ & Range & Mean & SD & $\mathrm{n}$ & Range & Mean & SD & $\mathrm{n}$ & Range & Mean & SD \\
\hline Standard length & 97 & $28.3-176.92$ & & & 198 & $53.8-245.2$ & & & 135 & $44.1-152.2$ & & \\
\hline \multicolumn{13}{|c|}{ Percents of Standard length } \\
\hline Head length & 95 & $26.7-32.9$ & 29.3 & 1.1 & 196 & $26.0-31.2$ & 29.1 & 0.8 & 134 & $27.8-32.5$ & 30.2 & 0.8 \\
\hline Body depth & 73 & $25.5-33.3$ & 29.8 & 1.6 & 136 & $25.2-33.2$ & 28.4 & 1.7 & 104 & $25.1-31.6$ & 28.4 & 1.3 \\
\hline Dorsal-fin length & 70 & $22.7-28.6$ & 25.6 & 1.1 & 128 & $20.2-27.2$ & 23.6 & 1.3 & 110 & $20.6-27.3$ & 24.2 & 1.2 \\
\hline Dorsal-fin base length & 97 & $10.5-13.4$ & 12.0 & 0.5 & 197 & $10.0-13.8$ & 11.8 & 0.6 & 135 & $10.8-14.3$ & 12.2 & 0.5 \\
\hline Pectoral-fin length & 93 & $13.2-18.8$ & 16.7 & 0.8 & 185 & $14.2-18.0$ & 16.1 & 0.5 & 126 & $14.7-19.1$ & 16.7 & 0.8 \\
\hline Pelvic-fin length & 94 & $11.3-14.8$ & 12.6 & 0.6 & 186 & $9.7-13.2$ & 12.0 & 0.5 & 118 & $9.8-13.9$ & 12.1 & 0.6 \\
\hline Anal-fin length & 60 & $11.2-16.1$ & 13.4 & 1.2 & 149 & $11.1-15.9$ & 13.4 & 0.9 & 98 & $11.6-17.4$ & 14.1 & 1.1 \\
\hline Anal-fin base length & 92 & $33.5-40.4$ & 37.5 & 1.1 & 194 & $31.5-39.0$ & 35.6 & 1.2 & 132 & $32.1-38.0$ & 35.4 & 1.0 \\
\hline Prepectoral distance & 97 & $27.7-34.8$ & 30.4 & 1.3 & 194 & $26.9-36.1$ & 30.1 & 1.1 & 133 & $28.4-35.9$ & 31.2 & 1.3 \\
\hline Prepelvic distance & 74 & $41.7-47.0$ & 44.0 & 1.1 & 142 & $40.5-47.5$ & 43.5 & 1.2 & 110 & $41.5-48.5$ & 44.8 & 1.3 \\
\hline Predorsal distance & 96 & $47.8-54.2$ & 50.6 & 1.0 & 193 & $47.5-53.9$ & 50.1 & 1.2 & 135 & $48.1-53.5$ & 50.6 & 0.9 \\
\hline Preanal distance & 96 & $52.5-61.8$ & 57.7 & 1.4 & 187 & $54.7-63.8$ & 58.9 & 1.7 & 135 & $55.9-63.0$ & 59.2 & 1.4 \\
\hline Caudal-peduncle depth & 86 & $6.6-9.3$ & 8.3 & 0.4 & 179 & $6.9-9.3$ & 8.0 & 0.4 & 132 & $6.9-9.0$ & 7.8 & 0.3 \\
\hline Caudal-peduncle length & 84 & $7.7-10.8$ & 9.5 & 0.6 & 190 & $7.7-12.3$ & 10.1 & 0.6 & 130 & $8.5-11.3$ & 10.1 & 0.5 \\
\hline \multicolumn{13}{|c|}{ Percents of Head length } \\
\hline Snout length & 96 & $29.9-35.9$ & 32.7 & 1.2 & 198 & $30.0-38.1$ & 32.9 & 1.6 & 135 & $28.9-36.1$ & 32.4 & 1.3 \\
\hline Orbital diameter & 96 & $23.5-32.3$ & 27.4 & 1.8 & 198 & $22.2-33.1$ & 27.8 & 2.3 & 135 & $27.7-36.2$ & 31.2 & 1.7 \\
\hline Interorbital distance & 94 & $18.0-29.4$ & 25.7 & 1.9 & 196 & $18.5-25.3$ & 22.3 & 1.2 & 135 & $19.0-26.0$ & 22.3 & 1.4 \\
\hline Upper jaw length & 96 & $64.1-71.4$ & 68.3 & 1.2 & 196 & $64.2-73.0$ & 67.8 & 1.7 & 135 & $64.5-71.8$ & 68.3 & 1.4 \\
\hline
\end{tabular}

Tab. 7. Morphometric data of specimens of Galeocharax gulo from río Orinoco, rio Tapajós and rio Oyapok basins. SD = standard deviation. Standard length in $\mathrm{mm}$.

\begin{tabular}{|c|c|c|c|c|c|c|c|c|c|c|c|c|}
\hline \multicolumn{13}{|c|}{ Galeocharax gulo } \\
\hline & \multicolumn{4}{|c|}{ Orinoco } & \multicolumn{4}{|c|}{ Tapajós } & \multicolumn{4}{|c|}{ Oyapok } \\
\hline & $\mathrm{n}$ & Range & Mean & $\mathrm{SD}$ & $\mathrm{n}$ & Range & Mean & SD & $\mathrm{n}$ & Range & Mean & SD \\
\hline Standard length & 41 & $29.7-151.3$ & & & 12 & $124.4-203.2$ & & & 2 & $104.7-139.9$ & & \\
\hline \multicolumn{13}{|c|}{ Percents of Standard length } \\
\hline Head length & 41 & $27.0-31.1$ & 28.8 & 1.1 & 12 & $28.6-31.8$ & 30.4 & 0.9 & 2 & $29.7-31.1$ & 30.4 & 0.9 \\
\hline Body depth & 32 & $26.6-31.1$ & 29.5 & 1.1 & 6 & $27.1-30.9$ & 28.5 & 1.4 & 2 & $29.2-29.5$ & 29.4 & 0.2 \\
\hline Dorsal-fin length & 29 & $22.4-29.4$ & 25.7 & 1.5 & 4 & $22.2-23.2$ & 22.6 & 0.5 & 2 & $25.5-26.2$ & 25.9 & 0.4 \\
\hline Dorsal-fin base length & 41 & $11.0-13.3$ & 12.1 & 0.5 & 12 & $11.0-13.0$ & 11.7 & 0.6 & 2 & $11.7-11.8$ & 11.7 & 0.0 \\
\hline Pectoral-fin length & 38 & $14.5-18.5$ & 16.8 & 0.8 & 11 & $15.9-17.3$ & 16.7 & 0.4 & 2 & $17.9-18.0$ & 17.9 & 0.0 \\
\hline Pelvic-fin length & 37 & $10.8-14.4$ & 12.5 & 0.7 & 12 & $11.1-12.8$ & 12.0 & 0.4 & 2 & $12.9-13.6$ & 13.2 & 0.4 \\
\hline Anal-fin length & 27 & $11.5-19.5$ & 13.8 & 1.8 & 7 & $13.0-15.5$ & 14.2 & 0.8 & 2 & $14.1-14.8$ & 14.5 & 0.4 \\
\hline Anal-fin base length & 41 & $36.7-41.2$ & 38.9 & 1.0 & 10 & $32.8-35.9$ & 33.8 & 1.0 & 2 & $37.1-39.1$ & 38.1 & 1.3 \\
\hline Prepectoral distance & 40 & $27.3-35.0$ & 29.5 & 1.5 & 12 & $29.9-33.1$ & 31.2 & 1.0 & 2 & $31.1-35.0$ & 33.0 & 2.7 \\
\hline Prepelvic distance & 34 & $40.3-45.9$ & 42.6 & 1.1 & 6 & $43.8-46.0$ & 45.4 & 0.8 & 2 & $43.3-45.9$ & 44.6 & 1.8 \\
\hline Predorsal distance & 41 & $48.2-52.2$ & 50.1 & 0.8 & 12 & $49.7-53.1$ & 51.3 & 0.9 & 2 & $49.3-50.3$ & 49.8 & 0.7 \\
\hline Preanal distance & 40 & $54.7-59.4$ & 56.9 & 1.2 & 12 & $58.1-63.1$ & 60.4 & 1.4 & 2 & $57.1-59.5$ & 58.3 & 1.7 \\
\hline Caudal-peduncle depth & 41 & $6.9-8.4$ & 7.7 & 0.3 & 10 & $7.3-8.2$ & 7.8 & 0.3 & 2 & $7.8-7.8$ & 7.8 & 0.0 \\
\hline Caudal-peduncle length & 38 & $8.0-10.9$ & 9.2 & 0.6 & 9 & $10.3-11.3$ & 10.8 & 0.3 & 2 & $9.2-9.7$ & 9.5 & 0.3 \\
\hline \multicolumn{13}{|c|}{ Percents of Head length } \\
\hline Snout length & 42 & $30.2-34.9$ & 31.9 & 1.1 & 12 & $32.1-35.2$ & 33.5 & 0.8 & 2 & $29.3-31.8$ & 30.5 & 1.7 \\
\hline Orbital diameter & 42 & $25.4-32.4$ & 29.1 & 1.4 & 11 & $26.5-30.4$ & 28.4 & 1.4 & 2 & $31.2-32.0$ & 31.6 & 0.5 \\
\hline Interorbital distance & 41 & $19.7-27.7$ & 24.1 & 1.6 & 12 & $20.2-23.1$ & 21.3 & 1.0 & 2 & $21.3-22.6$ & 21.9 & 0.8 \\
\hline Upper jaw length & 42 & $63.8-70.1$ & 67.3 & 1.3 & 12 & $65.3-69.2$ & 67.4 & 1.1 & 2 & $68.0-70.7$ & 69.3 & 1.8 \\
\hline
\end{tabular}


Table 8. Frequency distribution of number of scale rows between the dorsal-fin origin and lateral line of specimens of Galeocharax gulo from various drainages.

\begin{tabular}{lccccccc}
\hline & 14 & 15 & 16 & 17 & 18 & 19 & Total \\
\hline Upper Paraná & 10 & 94 & 55 & 3 & & & 162 \\
Amazonas & & & 17 & 43 & 18 & 2 & 80 \\
Orinoco & & & 2 & 24 & 6 & 1 & 33 \\
Tocantins & 2 & 36 & 66 & 13 & & & 117 \\
\hline
\end{tabular}

Tab. 9. Frequency distribution of number of scale rows between the lateral line and the pelvic-fin origin of specimens of Galeocharax gulo from various drainages.

\begin{tabular}{|c|c|c|c|c|c|c|c|c|}
\hline & 10 & 11 & 12 & 13 & 14 & 15 & 16 & Total \\
\hline Upper Paraná & & 5 & 79 & 73 & 8 & & & 165 \\
\hline Amazonas & & & & 7 & 34 & 37 & 7 & 85 \\
\hline Orinoco & & & & 18 & 12 & 7 & & 37 \\
\hline Tocantins & & 5 & 58 & 59 & & & & 122 \\
\hline
\end{tabular}

Very few specimens from the rio Tapajós are present in collections, only nine specimens of three lots (MNRJ 23654, MZUSP 62839, and MZUSP 62841) were examined in the present study. Meristic and morphometric characters of those specimens are summarized in Tabs. 7 and 13. All those specimens show the diagnostic characters of G. gulo, however there are some subtle differences between the specimens from the rio Tapajós and those from the rest of the distribution range of G. gulo concerning the range of variation and frequency distribution of the number of scales between the lateral line and the pelvic-fin origin 10 (1), 11 (4), or 12 (2) (vs. 11-16), number of maxillary teeth 47 (1), 48 (1), 52 (2), 53 (1), 54 (1), 56 (2), or 57 (1) (vs. 35-55), and number of branched anal-fin rays 34 (2), 35 (2), 36 (4), or 37 (1) (vs. 33-46). The frequencies of distribution of theses features for the specimens from the rio Tapajós are more similar to the frequencies of distribution observed for specimens from the upper rio Paraná and the rio Tocantins basins (Tabs. 9-11, respectively). Specimens from the rio Tapajós have 40 (7) total vertebrae which is also more similar to the counts of vertebrae of specimens from the rio Tocantins (Tab. 12). The range of variation of the number of teeth on the external row of the premaxilla 10 (2), 11 (3), or 13 (4) of the specimens from the rio Tapajós also differs from that of the rest of the distribution range of G. gulo, however overlapping also occurs. Specimens from the rio Tapajós have 5 (7) supraneurals, which is relatively uncommon when compared with the rest of the specimens of G. gulo 4 (80) or 5 (7). In view of the lack of any features that unambiguously characterize, the specimens from rio Tapajós as a distinct species, they are tentatively identified as G. gulo.

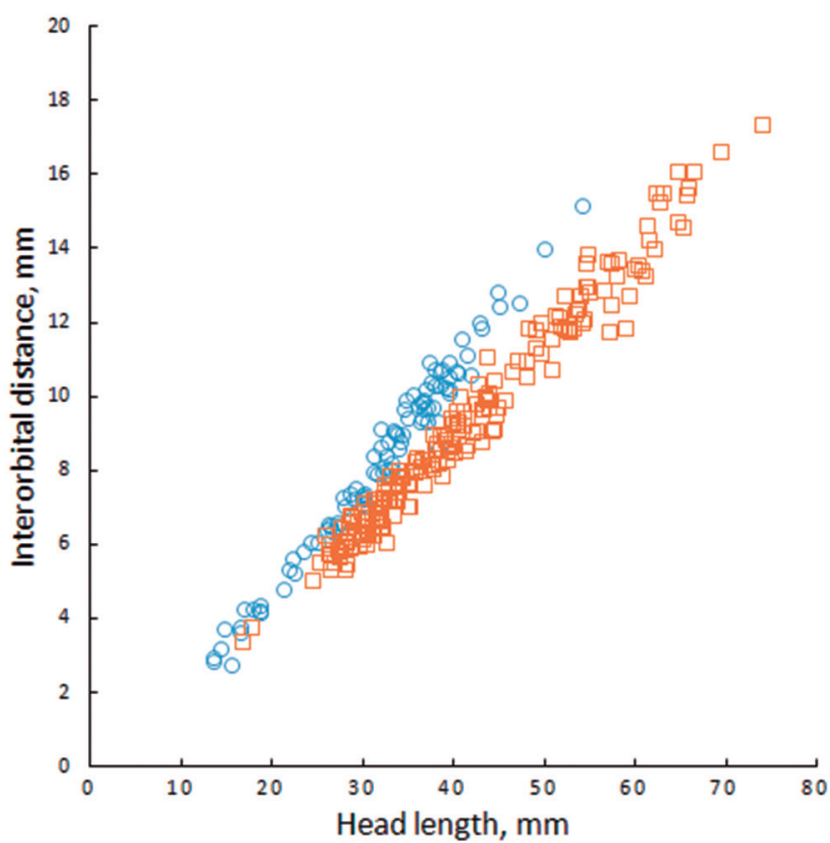

Fig. 14. Scatter plot of interorbital distance $v s$. head length of specimens of Galeocharax gulo from rio Amazonas (circles) and upper rio Paraná basins (squares).

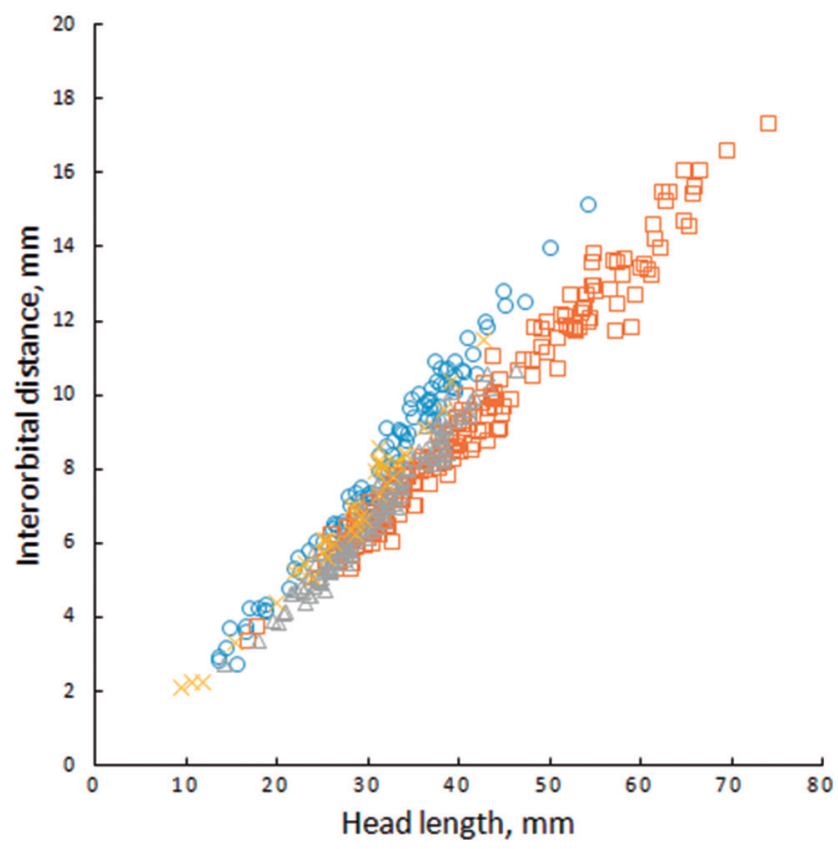

Fig. 15. Scatter plot of interorbital distance $v s$. head length of specimens of Galeocharax gulo from rio Amazonas (circles), upper rio Paraná (squares), río Orinoco $(\mathrm{X})$ and rio Tocantins basins (triangles).

Tab. 10. Frequency distribution of number of maxillary teeth of specimens of Galeocharax gulo from various drainages.

\begin{tabular}{lcccccccccccccccccccccccc}
\hline & 35 & 36 & 37 & 38 & 39 & 40 & 41 & 42 & 43 & 44 & 45 & 46 & 47 & 48 & 49 & 50 & 51 & 52 & 53 & 54 & 55 & 56 & 57 & Total \\
\hline Upper Paraná & & & & & & 5 & 7 & 12 & 15 & 22 & 21 & 27 & 23 & 17 & 12 & 10 & 16 & 5 & 1 & 2 & & & 195 \\
Amazonas & 3 & 3 & 5 & 8 & 8 & 7 & 19 & 13 & 9 & 10 & 4 & 5 & & & & & & & & & & & 94 \\
Orinoco & & 1 & 1 & & & 2 & 2 & 5 & 2 & 9 & 9 & 4 & 3 & & & & & & & & & 38 \\
Tocantins & & & & & & & & 4 & 3 & 9 & 16 & 16 & 14 & 16 & 19 & 6 & 9 & 7 & 8 & 5 & 1 & & 133 \\
\hline
\end{tabular}




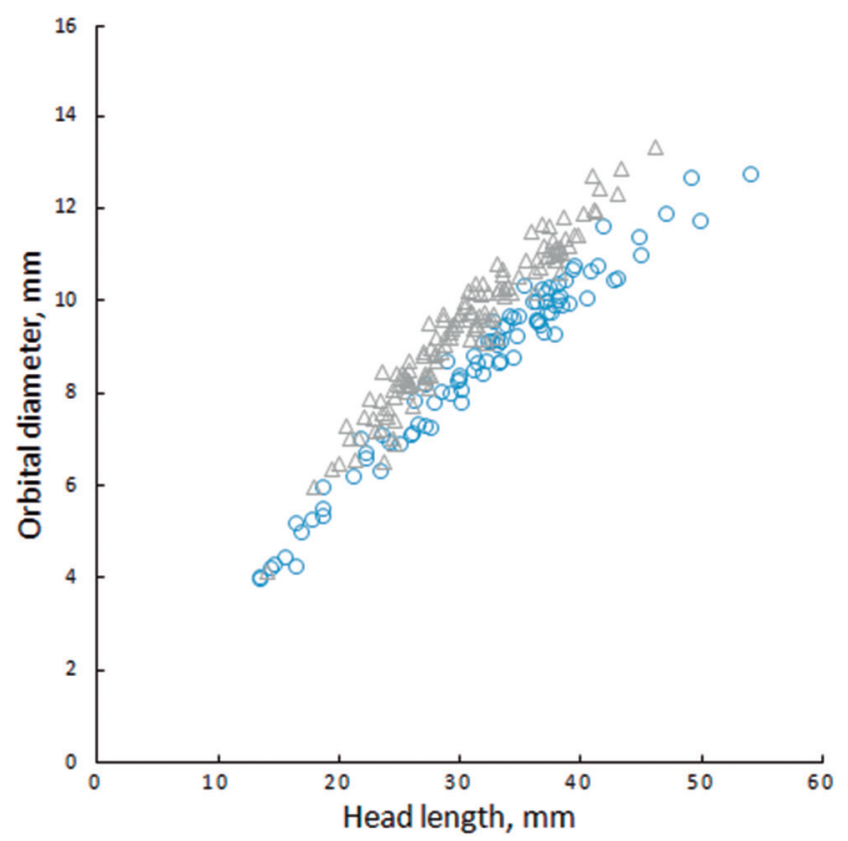

Fig. 16. Scatter plot of orbital diameter $v s$. head length of specimens of Galeocharax gulo from rio Amazonas (circles) and rio Tocantins basins (triangles).

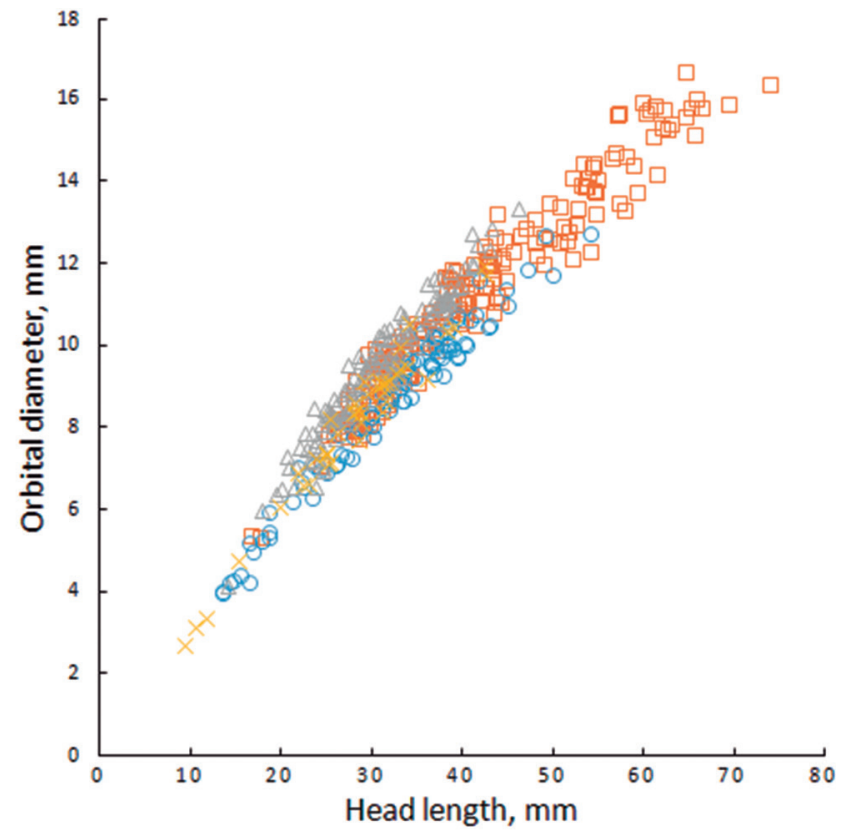

Fig. 17. Scatter plot of orbital diameter vs. head length of specimens of Galeocharax gulo from the rio Amazonas (circles), upper rio Paraná (squares), río Orinoco (X) and rio Tocantins basins (triangles).
Tab. 12. Frequency distribution of the total number of vertebrae of specimens of Galeocharax gulo from various drainages.

\begin{tabular}{|c|c|c|c|c|c|}
\hline & 39 & 40 & 41 & 42 & Total \\
\hline Upper Paraná & & 1 & 48 & 4 & 53 \\
\hline Amazonas & & & 18 & 6 & 24 \\
\hline Orinoco & & 2 & 9 & 1 & 12 \\
\hline Tocantins & 2 & 29 & 4 & & 35 \\
\hline
\end{tabular}

Planquette et al. (1996) reported the occurrence of specimens of Galeocharax in the rio Oyapok, French Guiana, and identified them as Galeocharax aff. gulo, based on an apparently lower number of lateral line scales than the reported by them for G. gulo (76-84 vs. 81-86). In the present study two specimens from the rio Oyapok drainage were examined and have 78 and 84 lateral-line scales. The large number of specimens examined in the present study showed that the range of variation in the number of lateral-line scales is larger than previously recognized for the species. In addition, all other meristic and morphometric characters of the specimens from the Oyapok river fall into the variation ranges herein observed for G. gulo.

No geographic variation in body proportions other than those discussed above was observed (Tabs. 6-7). Although it was possible to identify a few patterns of geographic variation in G. gulo, it was not possible to unequivocally diagnose different species based on the characteristics examined in the present study.

Remarks. Although the holotype of G. gulo (ANSP 8053, $73.9 \mathrm{~mm}$ SL, Fig. 18) was not examined during this study, data of that specimen is available in the literature (Tab. 5). In addition, examination of specimens originating from the region near the type locality, showed that meristic and morphometric data fall within the variation observed in the present study for G. gulo. Only data presented by Géry (1972) regarding number of teeth on the inner row of the premaxilla and number of maxillary teeth do not agree with the variation ranges observed during this study (3 vs. 2 and 31-36 vs. 35-55, respectively). Discrepancies in the number of premaxillary teeth are probably due to different ways of counting them (i.e. considering the canine teeth as part of the inner row or not). Regarding the maxillary teeth, it is common to find specimens with several fallen teeth, a fact that might have influenced the count reported by Géry (1972).

Tab. 11. Frequency distribution of the number of branched anal-fin rays of specimens of Galeocharax gulo from various drainages.

\begin{tabular}{lccccccccccccccc}
\hline & 33 & 34 & 35 & 36 & 37 & 38 & 39 & 40 & 41 & 42 & 43 & 44 & 45 & 46 & Total \\
\hline Upper Paraná & & & 2 & 3 & 12 & 24 & 54 & 47 & 34 & 11 & 5 & & & & 192 \\
Amazonas & & & & & 2 & 2 & 10 & 14 & 29 & 19 & 6 & 2 & 1 & 85 \\
Orinoco & & & & & & & 2 & 2 & 13 & 8 & 9 & 1 & 1 \\
Tocantins & 2 & 5 & 19 & 28 & 50 & 16 & 9 & & & & & & & 129 \\
\hline
\end{tabular}




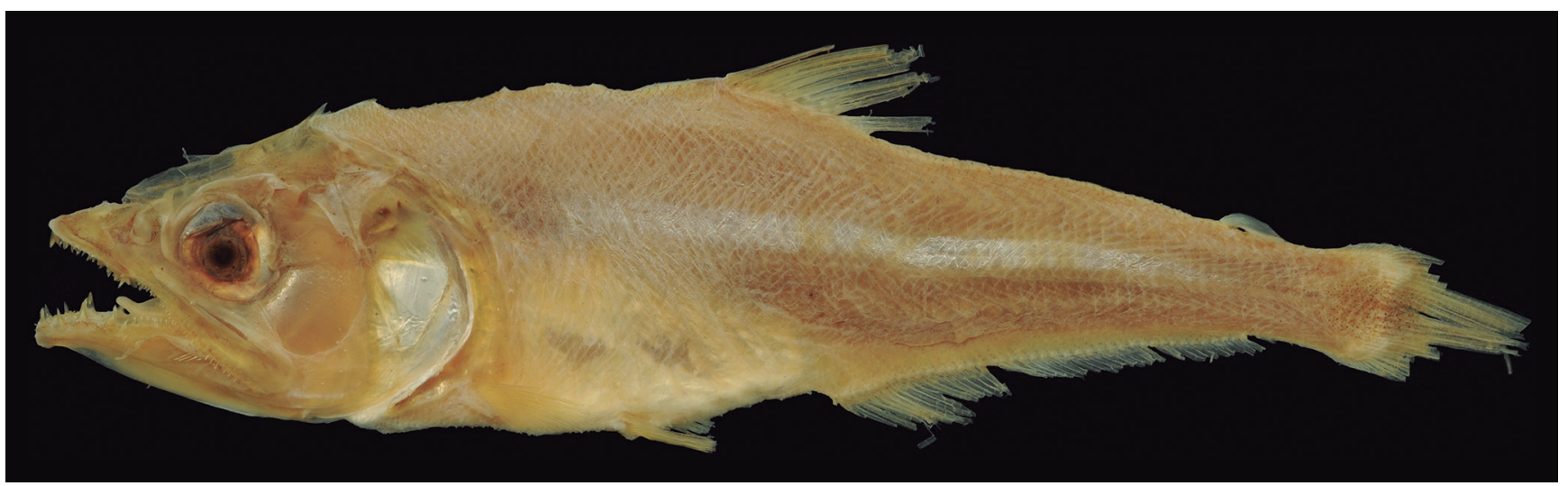

Fig. 18. Holotype of Cynopotamus gulo Cope, ANSP 8053, 73.9 mm SL, Peru, Pebas.

Tab. 13. Meristic characters of specimens of Galeocharax from the rio Tapajós basin.

\begin{tabular}{lcc}
\hline Character & Range & $\mathrm{n}$ \\
\hline Lateral-line scales & $78-82$ & 7 \\
Scale rows between dorsal-fin origin and lateral line & $15-16$ & 7 \\
Scale rows between lateral line and pelvic-fin origin & $10-12$ & 7 \\
Scale rows between lateral line and anal-fin origin & $14-16$ & 9 \\
Scale rows around caudal peduncle & $20-24$ & 6 \\
Branched anal-fin rays & $34-37$ & 9 \\
Teeth on maxilla & $47-57$ & 9 \\
Teeth on dentary inner row & $7-9$ & 6 \\
Teeth on pre-maxilla outer row & $10-13$ & 9 \\
Abdominal vertebrae & 16 & 7 \\
Caudal vertebrae & 24 & 7 \\
Total number of vertebrae & 40 & 7 \\
\hline
\end{tabular}

Galeocharax gulo was diagnosed from G. knerii on the basis of only two features: a deeper body and by the presence of fewer teeth on the posterior row of the dentary (Menezes, 1976, figs. 51 and 55, respectively). However, the examination of a larger number of specimens from the rio Amazonas, upper rio Paraná and rio Tocantins resulted in increase of the overlap of those characteristics considered as diagnostic for G. gulo and G. knerii (figs. 19; Tab. 14), and all the remaining meristic and morphometric characters (tabs. 6, 8-12, 14-16).

Menezes (1976: 41) reported the existence of ontogenetic variation in the number of teeth on the posterior row of the dentary, with larger specimens having a higher number of teeth. Larger specimens examined in the present study have more teeth than some of the small specimens, but there is individual variation in this feature (Fig. 20), so that the ontogenetic variation is not clearly reflected by the data.

Mattox, Toledo-Piza (2012) reported some osteological differences between specimens of Galeocharax from the rio Amazonas basin and the upper rio Paraná basin, that could help to diagnose two distinct forms. According to their observations specimens of Galeocharax from the rio Amazonas basin have the anterior margin of the palatine divided into two distinct articulation regions, a medial region associated with the neurocranium and a lateral region associated with the medial process of the maxilla. Those two regions are separated by a circular opening into which the tip of the largest dentary canine fits. Alternatively, specimens from the upper rio Paraná basin have the anterior margin of the palatine rounded, with a single articulation surface, a generalized condition in the Characiformes (Mattox, Toledo-Piza, 2012: 851). The examination of the material used by the authors in their study as well as the examination of additional cleared and stained material showed that all Galeocharax species have the same condition, which is intermediate between the two conditions described by Mattox, Toledo-Piza (2012). The anterior margin of the palatine in the specimens examined have two distinct articulation areas, one medial associated with the neurocranium and a lateral, associated with the medial process of the maxilla (Fig. 21). However, those two articular surfaces are separated by a subtle concavity on the anterior margin of the autopalatine that do not form a circular opening (the latter condition occurs in species of Cynopotamus).

Mattox, Toledo-Piza (2012: 853) also described that specimens of Galeocharax from the upper rio Paraná basin have the entire lateral margin of the ectopterygoid straight and a ligament connects the ventral surface of the maxilla to the lateral margin of the ectopterygoid. Alternatively, in specimens from the rio Amazonas basin, the lateral margin of the ectopterygoid has a bony lateral projection dorsoventraly flattened, where the cited ligament is attached (Fig. 21b). Examination of the material used by those authors confirmed the presence of the cited projection in G. gulo. However, an additional cleared and stained specimen of Galeocharax from the upper Paraná basin, of similar size to the specimen of Galeocharax from the rio Amazonas basin examined by the authors, also presents such lateral projection (Fig. 21f). This may indicate an ontogenetic variation of the character in the species, the gradual ossification of the base of the ligament connected to the lateral margin of the ectopterygoid. 


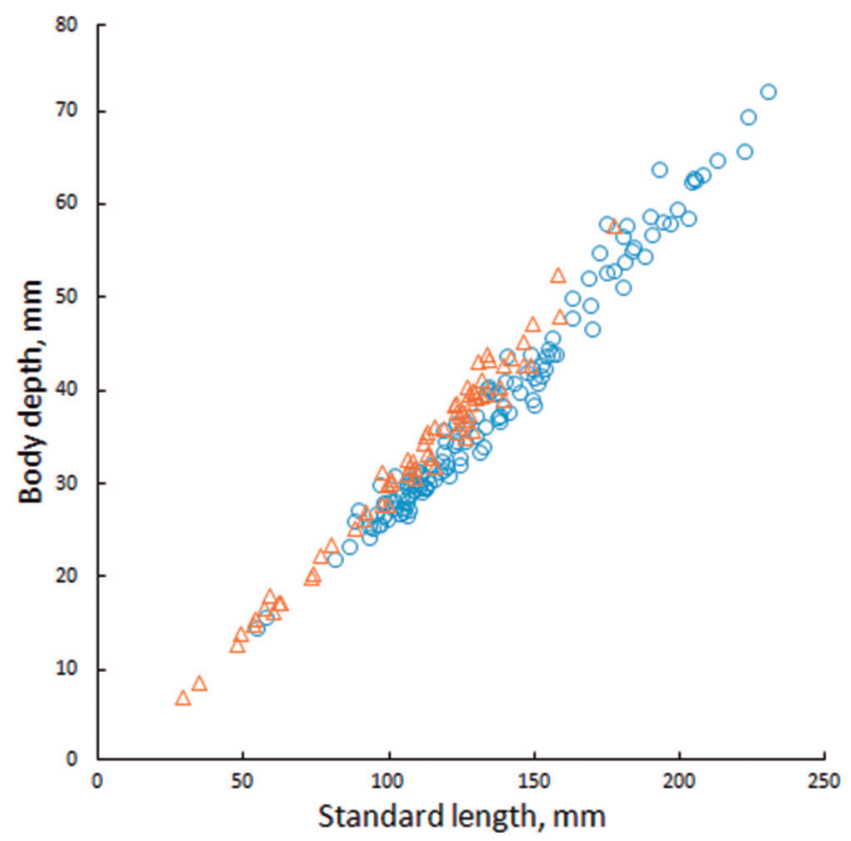

Fig. 19. Scatterplot of body depth vs. standard length of specimens of Galeocharax gulo from rio Amazonas (triangles) and upper rio Paraná (circles) basins.

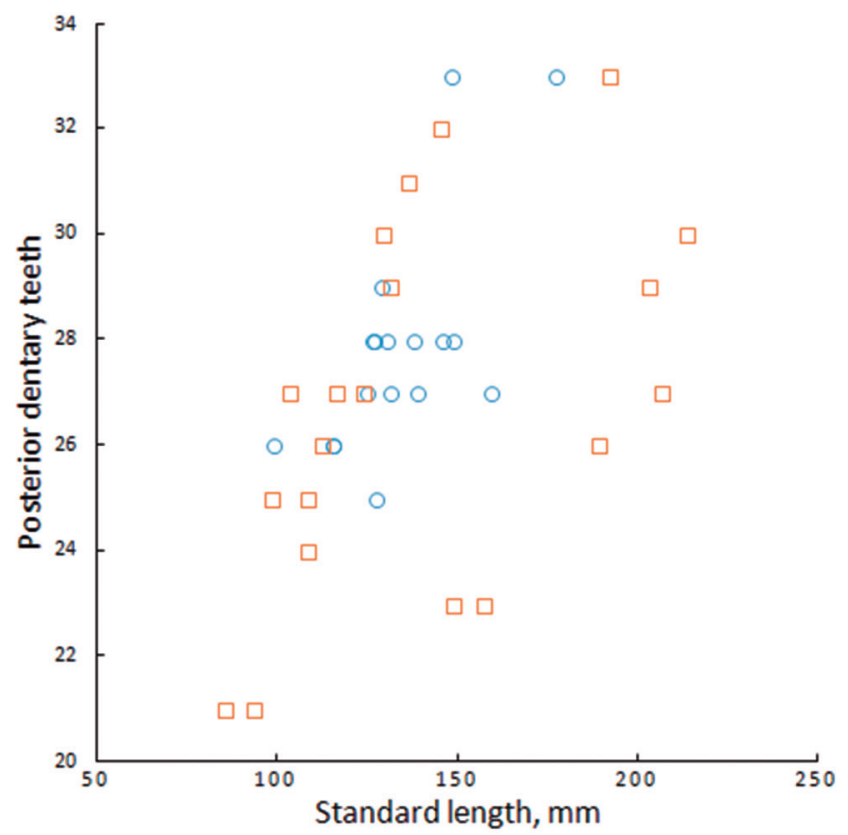

Fig. 20. Scatter plot of number of teeth on the posterior row of the dentary vs. standard length of specimens of Galeocharax gulo from rio Amazonas (circles) and upper rio Paraná (squares) basins.
A third difference reported by Mattox, Toledo-Piza (2012: 854) regards the presence in specimens of Galeocharax from the upper rio Paraná basin of an antero dorsal projection of the metapterygoid medially oriented and associated with the endopterygoid (vs. projection absent in specimens from rio Amazonas basin). However, the examination of additional material lead to a reinterpretation of the character and to the conclusion that the conditions reported by the cited authors are not distinct between specimens of Galeocharax from the rio Amazonas basin and upper rio Paraná basin (Fig. 3). Therefore, it could not be used as a diagnostic character between the herein considered synonym species.

Mattox, Toledo-Piza (2012) also reported that in specimens of Galeocharax from the upper rio Paraná basin, the posterior margin of the adductor operculi and levator operculi muscles are at the same vertical, while in Galeocharax from the rio Amazonas basin the posterior margin of the levator operculi is posterior to the posterior margin of the adductor operculi. This myological character was not evaluated in the present study.

Despite differences in the range of variation of characters such as perforated lateral line scales (Tab. 15), number of branched anal-fin rays (Tab. 11) and total number of vertebrae (Tab. 12) between specimens from the Tocantins river basin and specimens from the remaining distribution range of Galeocharax, the large overlap in the values complicates the recognition of specimens from the Tocantins as a distinct species.

None of the characteristics studied in the present study allow us to unequivocally recognize forms from the upper rio Paraná, rio Amazonas, and rio Tocantins as different species. Therefore $G$. knerii is herein considered a junior synonym of G. gulo, following the Principle of Priority (ICZN, 1999: art. 23). Information about the syntypes of G. knerii (Fig. 22) available in the literature are summarized on Tab. 5 .

Taphorn (1992: 185) reported the occurrence of Galeocharax in the río Apure, río Orinoco basin, Venezuela, but based on the range of variation of the characters of the specimens he examined, he was not able to identify the species as either $G$. gulo or $G$. $k n e r i i$. The author hence suggested that the specimens from the río Apure could probably represent an undescribed species. In the present study, 42 specimens from the río Orinoco basin were examined, including 14 specimens from the río Apure drainage. The number of perforated lateral-line scales of the specimens from the río Apure drainage varies from $80-84(\mathrm{n}=11)$, a range included in the range of variation of 79-84 reported by Taphorn (1992). The remaining meristic and morphometric data fall within the range of variation of specimens from the Amazon basin (Tabs. 6-11, 15-16). The specimens from the río Orinoco basin are herein identified as Galeocharax gulo.

Tab. 14. Frequency distribution of the number of teeth on the posterior row of the dentary of specimens of Galeocharax gulo from various drainages.

\begin{tabular}{lccccccccccccccc}
\hline & 21 & 22 & 23 & 24 & 25 & 26 & 27 & 28 & 29 & 30 & 31 & 32 & 33 & 34 & Total \\
\hline Upper Paraná & 2 & & 2 & 1 & 2 & 2 & 4 & & 2 & 2 & 1 & 1 & 1 & 20 \\
Amazonas & & & & & 1 & 3 & 4 & 6 & 1 & & & 2 & 1 \\
Tocantins & & & & & & 1 & 3 & 3 & 1 & 5 & 3 & 1 & 2 & 1 & 20 \\
\hline
\end{tabular}




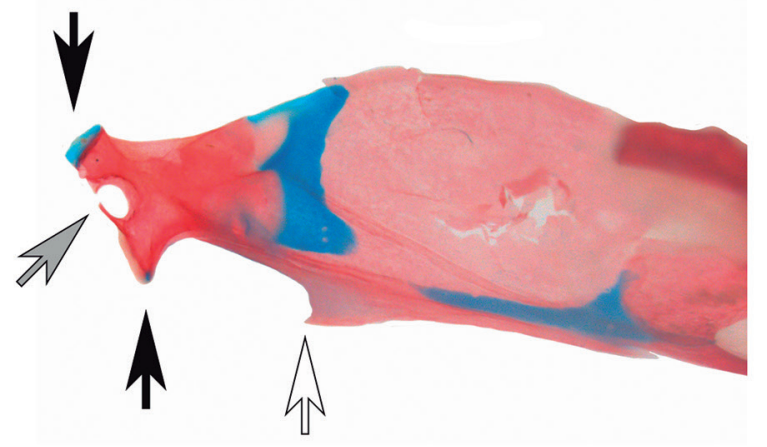

a

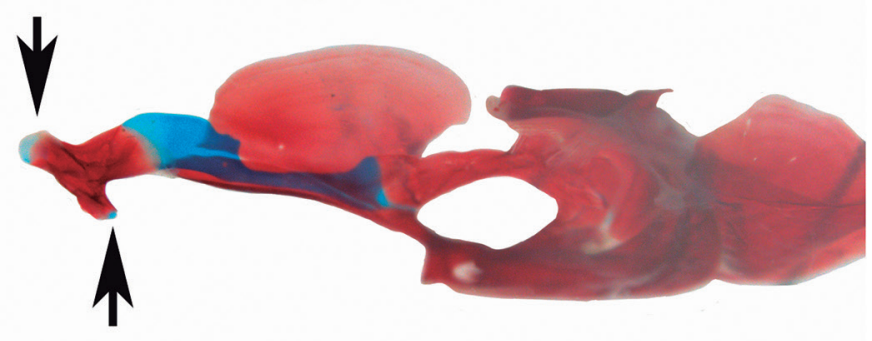

c

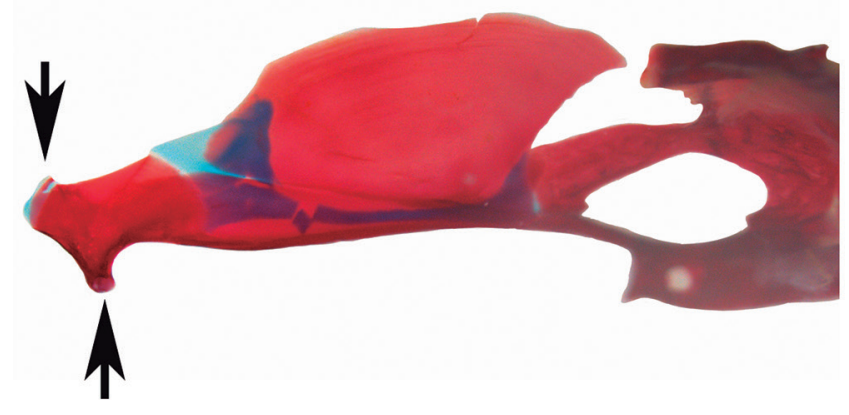

e
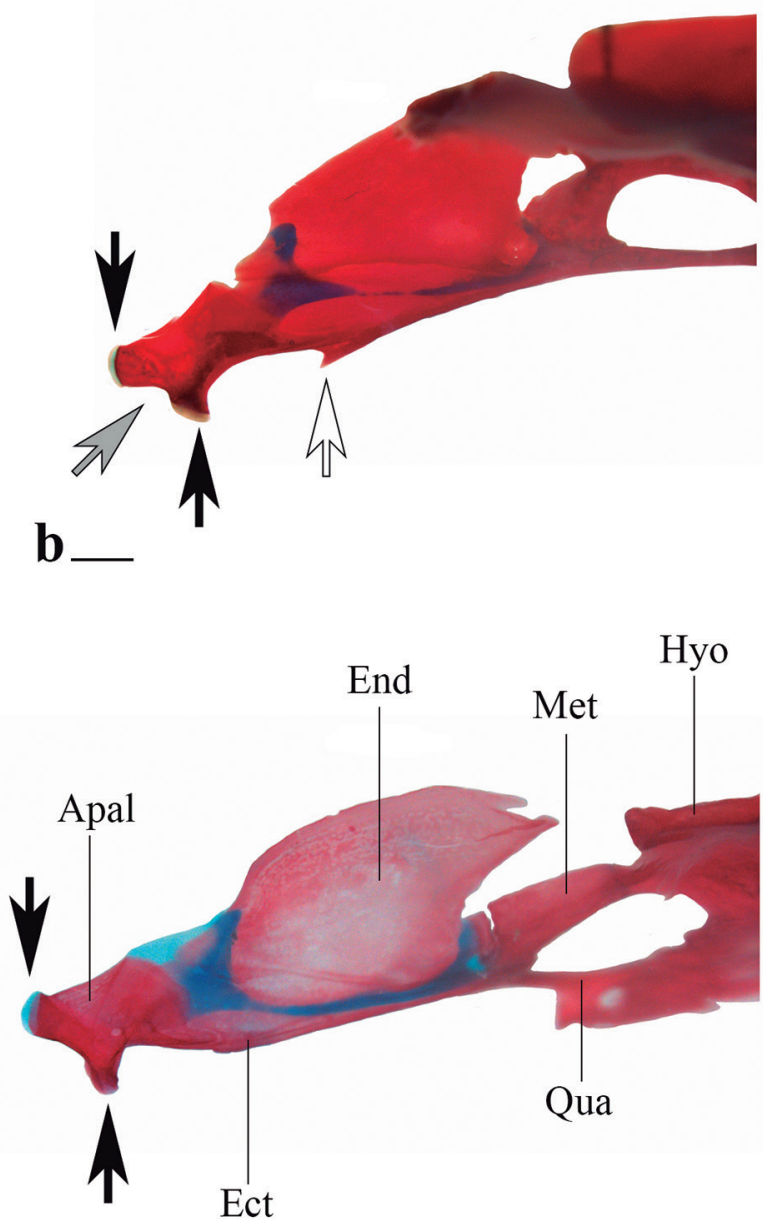

d

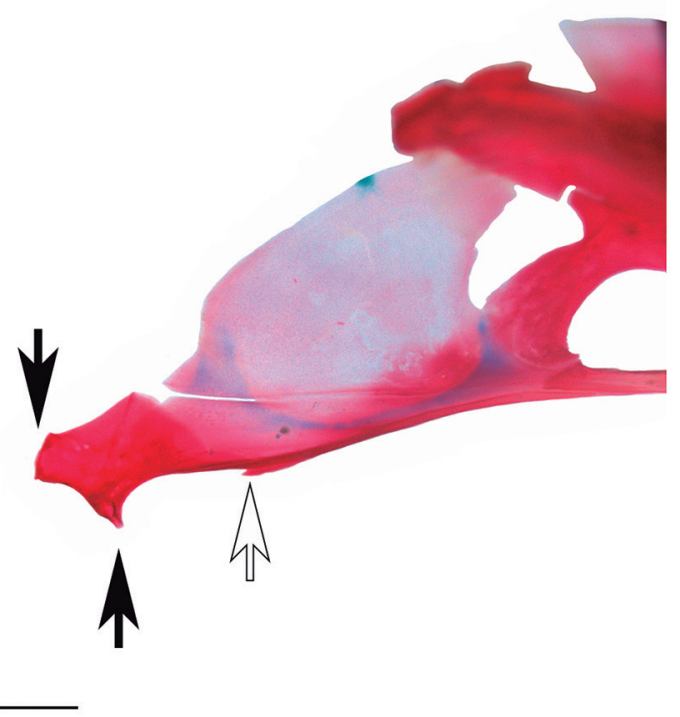

Fig. 21. Anterior portion of hyopalatine arch of a. Cynopotamus xinguano, MZUSP 94196, $97.9 \mathrm{~mm}$ SL; b. Galeocharax gulo, MZUSP 62839, $127.2 \mathrm{~mm}$ SL; c. G. humeralis, MZUSP 19984, $66.0 \mathrm{~mm}$ SL; d. G. goeldii, UFRO-I 5468, $77.9 \mathrm{~mm}$ SL; e. G. gulo, MZUSP 10480, $88.8 \mathrm{~mm}$ SL and f. G. gulo, NUP 3119, $94.4 \mathrm{~mm}$ SL. Left side, dorsal view. Black arrows point to regions of articulation of the autopalatine, gray arrows point to area between the articular regions of the autopalatine, white arrows point to lateral projection of the ectopterygoid. Apal - autopalatine; Ect - ectopterygoid; End - endopterygoid; Hyo - hyomandibular; Met - metapterygoid; Qua - quadrate. Scale bars $2 \mathrm{~mm}$. 


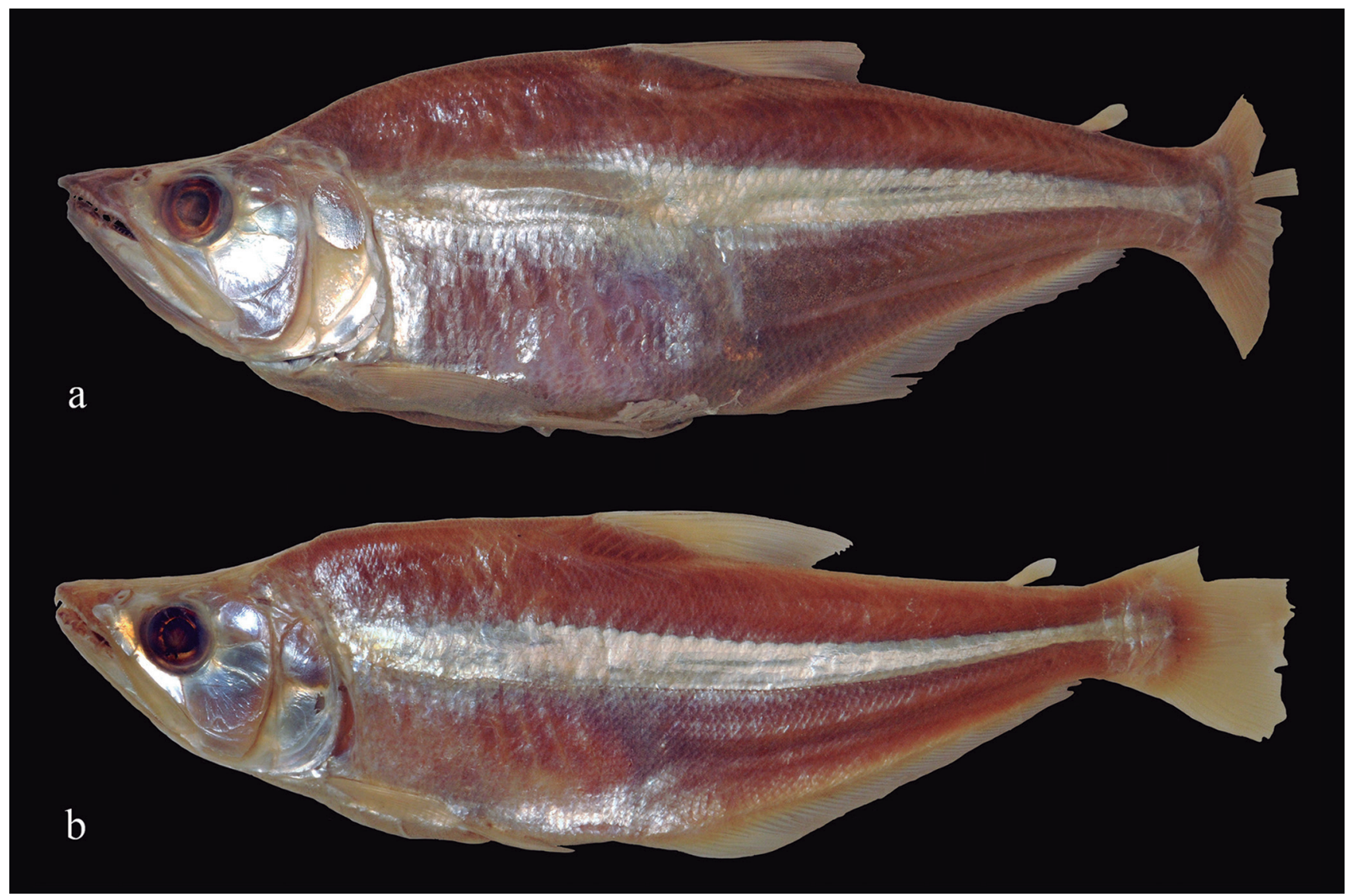

Fig. 22. Syntypes of Anacyrtus (Cynopotamus) knerii Steindachner, NMW 62660, a. $210.5 \mathrm{~mm} \mathrm{SL}$, and b. $161.1 \mathrm{~mm}$ SL (Oriçanga, São Paulo).

Tab. 15. Frequency distribution of the number of perforated lateral-line scales of specimens of Galeocharax gulo from various drainages.

\begin{tabular}{lcccccccccccc}
\hline & 77 & 78 & 79 & 80 & 81 & 82 & 83 & 84 & 85 & 86 & 87 & Total \\
\hline Upper Paraná & & & 6 & 18 & 24 & 41 & 37 & 19 & 14 & 10 & 6 & 175 \\
Amazonas & & & & 11 & 11 & 11 & 20 & 18 & 9 & 3 & 2 & 85 \\
Orinoco & & & & 6 & 12 & 7 & 4 & 7 & & & & 36 \\
Tocantins & 3 & 17 & 46 & 37 & 10 & 11 & 2 & 3 & & & & 129 \\
\hline
\end{tabular}

Tab. 16. Frequency distribution of the number of scale rows around the caudal-peduncle of specimens of Galeocharax gulo from various drainages.

\begin{tabular}{lccccccccc}
\hline & 19 & 20 & 21 & 22 & 23 & 24 & 25 & 26 & Total \\
\hline Upper Paraná & 6 & 26 & 22 & 32 & 21 & 4 & & & 111 \\
Amazonas & & 3 & 8 & 16 & 14 & 15 & 10 & 5 & 71 \\
Orinoco & 1 & 3 & 2 & 4 & 8 & 3 & 4 & & 25 \\
Tocantins & & & 15 & 25 & 38 & 19 & & & 97 \\
\hline
\end{tabular}

Material examined. Brazil: Acre: MCP 38018, 1, 129.4 mm SL; MZUSP 20512, 1; MZUSP 29882, 4, 23.6-108.3 mm SL; MZUSP 31754, 1, $99.1 \mathrm{~mm}$ SL; MZUSP 35791, 1, $59.3 \mathrm{~mm}$ SL; MZUSP 49649, 1, $53.4 \mathrm{~mm}$ SL; MZUSP 49673, 7, 24.6-62.3 mm SL; MZUSP 49841, 1, $1573 \mathrm{~mm}$ SL; MZUSP 50140, 7, 13.4-29.9 mm SL; MZUSP 50440, 2, 106.9-141.5 mm SL; MZUSP 50441, 1,
133.8 mm SL; MZUSP 53017, 1, 166.9 mm SL; MZUSP 104480, 2, 131.8-161.3 mm SL; MZUSP 104919, 1, 113.9 mm SL. Amazonas: AMNH 221401, 1, $99.8 \mathrm{~mm}$; INPA 2482, 1, $98.9 \mathrm{~mm}$ SL; INPA 29326, 1, 159.0 mm SL; MZUSP 1683, 1, 145.4 mm SL; MZUSP 10424-33, 10, 22.0- 44.0 mm SL; MZUSP 10435-36, 2, 96.9-131.1 mm SL; MZUSP 10437, 1, 99.8 mm SL; MZUSP 10438, 1, 105.5 mm SL; MZUSP 10439-40, 2, 115.3-138.8 mm SL; MZUSP 1044142, 2, 118.4-158.7 mm SL; MZUSP 10443-47, 5, 139.1-176.5 mm SL; MZUSP 20066, 1, 21.3 mm SL; MZUSP 20085, 2, 112.1-124.1 mm SL; MZUSP 20117, 1, 48.5 mm SL; MZUSP 20515, 1, 137.7 mm SL. Goiás: MCP 14405, 1, 124.1 mm SL; MCP 19771, 9, 85.9106.9 mm SL; MCP 41380, 1, 134.4 mm SL; MCP 41407, 1, 120.3 mm SL; MCP 41837, 1, 127.5 mm SL; MCP 42288, 4, 98.4-110.3 mm SL; MCP 42351, 1, 101.0 mm SL; MCP 43771, 1, $108.3 \mathrm{~mm}$ SL; MCP 45561, 1, 128.4 mm SL; MNRJ 12599, 4, 107.3-139.0 mm SL; MNRJ 12744, 8, 110.0-141.3 mm SL; MNRJ 13071, 2, 48.6-59.3 mm SL; MNRJ 13272, 15, 65.5-99.5 mm SL; MNRJ 17617, 1, $219.0 \mathrm{~mm}$ SL; MNRJ 17618, 3, 200.2-225.5 mm SL; MNRJ 18539, 5, 67.9-89.1 mm SL; MNRJ 19831, 1, 119.6 mm SL; MNRJ 19832, 6, 145.5-206.6 mm SL; MNRJ 19833, 1, $131.6 \mathrm{~mm}$ SL; MNRJ 19834, 7, 103.4-224.9 mm SL; MNRJ 19835, 1, 122.7 mm SL; MNRJ 26044, 1, 190.0 mm SL; MNRJ 31243, 14, 122.3$222.9 \mathrm{~mm}$ SL; MZUSP 35500, 2, 229.7-245.2 mm SL; MZUSP 40583, 1, $106.7 \mathrm{~mm} \mathrm{SL}$; MZUSP 40736, 1; MZUSP 40901, 2, 110.6-122.9 mm SL; MZUSP 74271, 2, 73.0-90.1 mm SL; NUP 
1128, 8, 91.8-174.2 mm SL; NUP 1199,13, 102.7-149.0 mm SL; NUP 1215, 21, 117.7-197.2 mm SL; NUP 1338, 2, 106.8-137.1 mm SL; NUP 3809, 1, 151.5 mm SL; NUP 8778, 1, 191.5 mm SL; NUP 8779, 1, 125.0 mm SL; NUP 8780, 1, 134.0 mm SL; NUP 8781, 2, 142.0-142.9 mm SL; NUP 9275, 1, 146.4 mm SL; NUP 13708, 2, 96.3-103.1 mm SL; NUP 13723, 1, 95.9 mm SL; NUP 13826, 2, 124.6-154.2 mm SL; NUP 14144, 2, 106.5-221.4 mm SL; NUP 14152, 2, 202.0-203.0 mm SL; NUP 14206, 2, 137.1-194.7 mm SL; NUP 14237, 2, 137.8-213.1 mm SL; UERJ 22, 3, 109.7-125.1 mm SL; UNT 708, 2, 129.8-136.6 mm SL. Maranhão: MNRJ 39674, 16, 98.9-129.9 mm SL; MZUSP 4987, 1, $44.1 \mathrm{~mm} \mathrm{SL;} \mathrm{MZUSP}$ 10448, 1, 39.6 mm SL; UNT 3225, 1, 98.1 mm SL. Mato Grosso: INPA 31750, 1, 127.2 mm SL; MNRJ 23654, 2, 127.4-145.6 mm SL; MZUSP 10449, 1, 106.6 mm SL; MZUSP 62839, 4, 124.4$203.2 \mathrm{~mm}$ SL; MZUSP 62841, 3, 148.9-180.8 mm SL; Mato Grosso do Sul: MZUSP 10476-78, 3, 151.8-183.2 mm SL; MZUSP 10479, 1, 179.7 mm SL; NUP 9181, 1, 71.4 mm SL. Minas Gerais: MNRJ 16991, 5, 101.7-131.3 SL; MNRJ 16992, 1, 133.4 mm SL; MNRJ 17027, 1, 133.3 mm SL; MNRJ 17038, 1, 140.9 mm SL; MZUSP 1660, 1, 155.2 mm SL; MZUSP 20466, 2, 121.5-166.9 mm SL; MZUSP 20485, 4, 105.4-204.5 mm SL; MZUSP 38869, 18, 101.0-213.9 mm SL; NUP 260, 2, 60.7-112.7 mm SL; NUP 13682, 2, 110.5-111.4 mm SL; NUP 13699, 2, 114.0-132.9 mm SL; NUP 13747, 2, 125.7-146.5 mm SL; NUP 13823, 2, 106.2-123.2 mm SL; NUP 13934, 2, 150.1-170.3mm SL; NUP 14014, 2, 133.2-193.2 mm SL; NUP 14039,2, 134.5-162.3 mm SL; NUP 14188, 2, 87.8190.9 mm SL; NUP 14238, 2, 157.7-160.9 mm SL; NUP 14357, 2, 135.6-136.6 mm SL; NUP 14378, 2, 164.2-221.2 mm SL. Pará: INPA 12320, 2, 99.1-123.3 mm SL; INPA 15243, 5, 78.4-84.5 mm SL; INPA 20954, 1, 106.4 mm SL; MCP 36354, 19, 113.4-148.9 mm SL; MZUSP 106939, 2, 89.4-108.2 mm SL. Paraná: MNRJ 27411, 1, 222.9 mm SL; MNRJ 27554, 1, 205.7 mm SL; MZUSP 21079, 4, 125.9-188.6 mm SL; MZUSP 21612, 8, 139.9-178.5 mm SL; NUP 256, 2, 171.7-210.4 mm SL; NUP 257, 8, 90.7-192.1 mm SL; NUP 258, 2, 99.7-120.7 mm SL; NUP 259, 3, 104.8-162.6 mm SL; NUP 261, 1, 140.7 mm SL; NUP 262, 4, 72.7-82.7 mm SL; NUP 263, 7, 118.4-190.7 mm SL; NUP 2487, 12, 105.6-190.0 mm SL; NUP 2503, 2, 119.6-130.3 mm SL; NUP 3119, 10, 94.4-195.5 mm SL; NUP 3868, 3, 83.1-91.6 mm SL; NUP 4221, 9, 65.2-206.9 mm SL; NUP 11357, 1, 149.1 mm SL. São Paulo: MNRJ 15595, 1, 141.3 mm SL; MNRJ 19469, 1, 115.2 mm SL; MZUSP 326, 1, 222.9 mm SL; MZUSP 2031, 1, 217.5 mm SL; MZUSP 2039, 3, 144.5-189.0 mm SL; MZUSP 2073, 1, 198.5 mm SL; MZUSP 2925, 1, 174.4 mm SL; MZUSP 3422, 1, 151.7 mm SL; MZUSP 10450-75, 26, 53.8-150.6 mm SL; MZUSP 10480-86, 4, 80.5-136.4 mm SL; MZUSP 10487-501, 15, 85.8-193.4 mm SL; MZUSP 10502, 5, 101.2-139.4 mm SL; MZUSP 10511-13, 3, 109.5-162.1 mm SL; MZUSP 10514, 14, 118.3-179.7 mm SL; MZUSP 10528, 2 , 148.5-174.0 mm SL; MZUSP 10529, 1, 194.2 mm SL; MZUSP 10530-32, 3, 178.8-196.8 mm SL; MZUSP 10533-41, 9, 83.9-144.5 mm SL; MZUSP 10542-55, 13, 90.9-129.5 mm SL; MZUSP 10556, 1, 135.7 mm SL; MZUSP 10557, 1, 153.0 mm SL; MZUSP 1055883, 26, 91.5-203.5 mm SL; MZUSP 10584-85, 2, 220.7-226.3 mm SL; MZUSP 20476, 6, 168.3-212.3 mm SL; MZUSP 25679, 4, 143.7-171.3 mm SL; MZUSP 42575, 1, 92.4 mm SL; MZUSP 53858, 9, 97.9-182.1 mm SL; MZSUP 53961, 8, 94.7-111.6 mm SL;
MZUSP 70387, 1, 221.6 mm SL; MZUSP 75426, 1, 155.4 mm SL; MZUSP 79318, 1, 95.6 mm SL; MZUSP 84298, 1; MZUSP 99198, 1, 122.6 mm SL; NUP 7018, 1, 113.5 mm SL; NUP 7043, 1, 96.4 mm SL; NUP 12380, 1, 242.8 mm SL; NUP 14467, 1, $229.1 \mathrm{~mm}$ SL; NUP 14478, 4, 150.2-189.8 mm SL; NUP 14516, 1, 194.8 mm SL. Tocantins: MCN 19060, 14, 99.8-150.9 mm SL; UNT 2584, 1, $82.1 \mathrm{~mm}$ SL; MZUSP 84002, 1, 140.5 mm SL; UNT 2588, 1, 86.5 mm SL; UNT 2589, 4, 70.6-90.4 mm SL; UNT 2590, 1, $70.3 \mathrm{~mm}$ SL; UNT 2596, 2, 68.6-75.6 mm SL; UNT 2606, 1, 105.8 mm SL; UNT 2607, 14, 39.7-74.9 mm SL; UNT 2608, 1, 78.3 mm SL; UNT 2612, 1, 75.4 mm SL; UNT 2613, 4, 52.9-81.1 mm SL; UNT 2616, 1, 60.6 mm SL; UNT 2620, 1, 83.9 mm SL; UNT 2622, 1, $43.8 \mathrm{~mm}$ SL; UNT 2623, 1, 84.0 mm SL; UNT 2624, 18, 29.4-65.3 mm SL; UNT 2626, 2, 61.8-83.2 mm SL; UNT 2628, 1, 64.8 mm SL; UNT 2630, 1, 42.8 mm SL; UNT 2631, 1, 50.2 mm SL; UNT 2634, 1, $44.5 \mathrm{~mm}$ SL; UNT 2635, 1, $36.7 \mathrm{~mm}$ SL; UNT 2636, 1, $74.3 \mathrm{~mm}$ SL; UNT 2639, 1, 24.6 mm SL; UNT 2642, 1, 47.9 mm SL; UNT 2645, 2, 39.2-40.7 mm SL; UNT 2646, 1, 26.7 mm SL; UNT 2677, 1, 80.0 mm SL; UNT 2678, 1, 99.7 mm SL; UNT 2683, 1, 114.2 mm SL; UNT 2686, 1, 100.7 mm SL; UNT 2687, 1, 96.8 mm SL; UNT 2688, 1, 93.9 mm SL; UNT 2689, 1, 88.3 mm SL; UNT 2691, 3, 45.9-85.3 mm SL; UNT 2697, 3, 42.7-79.7 mm SL; UNT 2698, 1, $57.1 \mathrm{~mm}$ SL; UNT 2700, 4, 48.0-54.5 mm SL; UNT 2701, 2, 70.0$73.6 \mathrm{~mm}$ SL; UNT 2704, 1, $68.2 \mathrm{~mm}$ SL; UNT 2705, 1, $80.8 \mathrm{~mm}$ SL; UNT 2707, 3, 39.1-50.9 mm SL; UNT 2712, 1, 52.8 mm SL; UNT 2714, 1, $73.1 \mathrm{~mm}$ SL; UNT 3276, 1, $108.8 \mathrm{~mm}$ SL; UNT 3688, 1, 81.6 mm SL; UNT 4523, 5, 26.8-49.1 mm SL; UNT 4619, 1, 52.9 mm SL; UNT 5954, 28, 22.4-36.3 mm SL; UNT 5992, 1, 33.2 mm SL; UNT 6471, 2, 60.8-63.0 mm SL; UNT 6472, 1, 91.8 mm SL; UNT 6478, 1, 74.3 mm SL; UNT 6480, 1, 102.0 mm SL; UNT 6481, 1, 89.7 mm SL; UNT 6483, 3, 73.6-85.1 mm SL; UNT 6487, 1, 55.4 mm SL; UNT 6488, 1, 64.3 mm SL; UNT 6490, 1, $44.2 \mathrm{~mm} \mathrm{SL}$; UNT 6492, 1, 57.6 mm SL; UNT, 6494 1, $87.6 \mathrm{~mm}$ SL; UNT 6503, 1, $72.1 \mathrm{~mm}$ SL; UNT 6508, 1, 49.9 mm SL; UNT 6510, 1, 44.9 mm SL; UNT 6511, 1, 23.5 mm SL; UNT 9060, 5, 105.1-151.4 mm SL; UNT 9734, 55, 77.2-123.9 mm; UNT 9965, 8, 89.3-104.3 mm SL; UNT 11343, 1, 152.2 mm; UNT 12311, 1, 115.1 mm SL; UNT 12503, 1, 64.7 mm SL; UNT 12526, 3, 60.8-84.6 mm SL; UNT 12544, 2, 57.2-65.2 mm SL; UNT 12555, 1, 87.6 mm SL; UNT 12572, 1, 106.6 mm SL. Colombia: Meta: ANSP 128277, 2 , 100.8-102.2 mm SL; ANSP 131550, 2, 120.7-139.1 mm SL. French Guiana: Saint Georges d' l'Oyapok: MNHN 1998-1472, 1, 139.9 mm SL. Peru: Cuzco: MUSM 25807, 1, 138.8 mm SL; MUSM 32516, 1, 145.5 mm SL. Huánuco: MZUSP 110473, 1, $148.2 \mathrm{~mm}$ SL. Loreto: MUSM 494, 1, 128.3 mm SL; MUSM 6100, 1, 99.8 mm SL; MUSM 6815, 1, 112.7 mm SL; MUSM 7255, 1, 85.0 mm SL; MUSM 15144, 2, 106.0-122.3 mm SL; MUSM 18186, 3, 96.9$112.3 \mathrm{~mm}$ SL; MUSM 18611, 1, 76.3 mm SL; MUSM 20602, 15, 32.1-58.0 mm SL; MUSM 30417, 2, 75.6-79.3 mm SL; MUSM 35843, 1, 111.3 mm SL; MUSM 38270, 1, 176.9 mm SL; MUSM 40512, 2, 46.4-93.1 mm SL; MUSM 40532, 2, 105.6-127.1 mm SL; MZUSP 15259, 1, 52.7 mm SL. Madre de Dios: MUSM 22189, 1, $134.1 \mathrm{~mm}$ SL. Pasco: MUSM 30444, 1, $158.0 \mathrm{~mm}$ SL. Ucayali: MUSM 127, 2, 124.0-133.2 mm SL; MUSM 849, 4, 120.9-131.4 mm SL; MUSM 10436, 2, 61.5-69.6 mm SL; MUSM 13051, 1, 75.6 mm SL; MUSM 15207, 2, 73.1-87.6 mm SL; MUSM 27332 , 
4, 85.8-91.2 mm SL; MUSM 27693, 1, $127.2 \mathrm{~mm} \mathrm{SL;} \mathrm{MUSM}$ 28353, 1, 128.20 mm SL; MUSM 39472, 1, 72.7 mm SL; MUSM 42561, 1, 108.4 mm SL; MZUSP 25948, 4, 90.9-125.5 mm SL; MZUSP 26160, 2, 98.8-115.0 mm SL; MZUSP 26223, 1, $128.0 \mathrm{~mm}$ SL; USNM 229063, 1, 58.2 mm SL; USNM 280515, 1, 125.4 mm SL. Venezuela: Amazonas: ANSP 159742, 1, $109.1 \mathrm{~mm}$ SL; ANSP 159743, 1, 137.3 mm SL. Apure: ANSP 165269, 1, 79.0 mm SL; ANSP 192043, 2, 49.9-66.3 mm SL; MCNG 1459, 1, 107.9 mm SL; MCNG 43833, 3, 85.6-105.7 mm SL; MCNG 54050, 7, 29.7-83.9 mm SL. Barinas: MCNG 49082, 1, 102.3 mm SL. Bolivar: ANSP 15974, 1, 103.5 mm SL; ANSP 159744, 1, 93.7 mm SL; ANSP 159745, 1, 107.3 mm SL; MCNG 19236, 2, 73.3-97.8 mm SL. Cojedes: MCNG 24216, 2, 91.3-120.1 mm SL. Guarico: MZUSP 27982, 4, 101.4-123.1 mm SL; USNM 258535, 10, 87.0-151.3 mm SL. Monaguas: USNM 233699, 1, 72.0 mm SL.

\section{Galeocharax humeralis (Valenciennes, 1834)}

\section{Fig. 23}

Hydrocyon humeralis Valenciennes, 1834: plate 11, fig. 2 [original description; type locality South America (Buenos Aires, Argentina)]. -Valenciennes, 1847:9 [text].

Xiphorhamphus humeralis. -Müller, Troschel, 1844:93 [listed; South America]. -Müller, Troschel, 1845:18 [listed; South America].

Cynopotamus humeralis. -Valenciennes, 1849:320 [description]. -Kner, 1860:49 [part; only specimens from Cuiabá, rio Paraguai]. -Garman, 1890:13 [listed; part, only specimens from Rosario, lower río Paraná basin]. -Eigenmann, Eigenmann, 1891:58 [listed; part, only La Plata and Rosario, lower río Paraná basin]. -Schultz, 1944:296 [listed]. -Bertin, 1948:24 [catalogue of types]. -Schultz, 1950:67 [diagnosis in identification key]. -Aramburu, 1953:299 [description; Rosario, Paraná Pavon and San Pedro, lower río Paraná]. -Géry, Vu-Tân-Tuê, 1963a:149 [description].

Anacyrtus humeralis. -Kner, 1860 [part, only specimens from Cuiabá, rio Paraguai basin]. -Günther, 1864: 348 [description; Buenos Ayres = Buenos Aires]. -Perugia, 1891:649 [listed; Empedrado, Corrientes, Villa Maria, Matto Grosso = Mato Grosso, rio Paraguai]. -Goeldi, 1898:467 [listed; rio Paraguai basin, common name].

Cynopotamus knerii. -Eigenmann, Eigenmann, 1891:58 [listed; part, only Cujaba (= Cuiabá) and rio Paraguai]. -Eigenmann, McAtee, Ward, 1907:143 [listed; Bahia Negra and Corumbá, rio Paraguai basin]. -Fowler, 1945:158 [listed; part, only La Plata basin].

Eucynopotamus humeralis. -Eigenmann, 1907:770 [listed]. -Eigenmann, 1910:445 [listed; distribution: part, only La Plata basin].

Eucynopotamus knerii. - Eigenmann, 1910:445 [listed; distribution: part, only La Plata basin].

Galeocharax humeralis. -Fowler, 1910:790 [listed]. -Fowler, 1950:315 [listed; distribution: part, only rio Paraguai]. -Menezes, 1976:41 [synonymy, description, distribution]. -López et al., 1987 [listed: Argentina, lower río Paraná basin]. -Sverlij et al., 1998:15 [río Uruguay]. -Britski et al., 1999:52 [rio Paraguai basin]. -Lucena, Menezes, 2003:203 [listed, distribution]. -López et al., 2003:18 [listed, lower río Paraná basin]. -Zaniboni-Filho et al., 2004:25 [upper río Uruguay]. -Buckup et al., 2007:35 [listed, distribution]. -Zayas, Cordiviola, 2007:178 [conservation, La Plata basin]. -Copatti et al., 2009:181 [rio Jaguari, lower rio Paraná basin].

Cynopotamus (Acestrocephalus) humeralis. -Géry, Vu-Tân-Tuê, 1963b:240 [diagnosis in identification key]. -Géry, 1977:306 [listed].

Galeocharax knerii. -López et al., 2003:18 [listed, lower río Paraná basin].

Diagnosis. Galeocharax humeralis differs from its congeners in the presence of one to three small conical teeth between the third and fourth dentary canines (Fig. 7c) (vs. small conical teeth between the third and fourth dentary canines absent). It further differs from G. gulo in the higher number of perforated lateral-line scales (90-105 vs. 77-87, Tab. 1). Although there is overlap in the number of scales above and below the lateral line between $G$. humeralis and G. gulo, G. humeralis shows a tendency towards higher values of scales above (17-20, median 18 vs. 14-19, median 16 in G. gulo, Tab. 2) and below (14-16, median 15 vs. 11-16, median 13 in G. gulo, Tab. 3) the lateral line, respectively.

Description. Morphometric data of Galeocharax humeralis presented on Tab. 4. Largest specimen examined $251.8 \mathrm{~mm}$ SL. Body elongated, laterally compressed and moderately deep, largest body depth at vertical through dorsal-fin origin. Dorsal profile of head straight to slightly concave from tip of snout to posterior tip of supraoccipital spine. Dorsal profile of body slightly convex from posterior tip of supraoccipital spine to base of first dorsal-fin ray, posteroventrally slanted to slightly convex along dorsal-fin base. Dorsal profile from base of last dorsal-fin ray to caudal peduncle straight, slightly concave along caudal peduncle. Ventral profile of head and body convex from tip of lower jaw to anal-fin origin; posterodorsally slanted along anal-fin base; straight to slightly concave along caudal peduncle. Profile of posterior bony margin of opercle usually convex, rarely straight or concave.

Dorsal-fin origin situated anterior to half of SL, base of last dorsal-fin ray posterior to vertical through anal-fin origin. Proximal medial radial of first dorsal-fin pterygiophore inserted posterior to neural spine of ninth vertebra. Dorsal-fin rays ii,9. Profile of distal margin of dorsal fin straight, profile of posterior margin slightly concave in some specimens. Anal-fin origin situated at approximately half SL, proximal medial radial of first anal-fin pterygiophore situated posterior to haemal spine of $17^{\text {th }}(4)$ vertebra. Anal-fin rays v (3), 40 (2), 41 (4), 42 (8), 43 (26), 44 (24), 45 (19), 46 (11), 47 (2), or 48 (4). Anterior lobe of anal fin poorly developed, profile of distal margin of anal fin concave at anterior two thirds; slightly convex at posterior third. Pectoral-fin rays i,13 (14), 14 (61), 15 (34), or 16 (2), longest ray reaching pelvic-fin origin when fin is depressed. Profile of posterior margin of pectoral fin straight, four or five proximal rays shorter than 
others. Pelvic-fin origin situated anterior to vertical through dorsal-fin origin; pelvic-fin rays $i, 7$; longest ray reaching urogenital opening when fin is depressed in most examined specimens, but failing to reach anal-fin origin. Profile of posterior margin of pectoral fin slightly convex, fan-like aspect when extended. Caudal fin forked, principal rays $\mathrm{i}, 8,9, \mathrm{i}(4)$ dorsal procurrent rays 14 (1), 15 (2), or 17 (1), ventral procurrent rays 13 (3) or 14 (1); lower lobe longer and deeper than upper lobe. Many specimens larger than $200 \mathrm{~mm}$ SL with profile of posterior margin of caudal fin almost straight. Adipose fin present, its base situated anterior to vertical through base of last anal-fin ray.

Spinoid scales (Fig. 8) distributed along entire body, except on region of axilla of paired fins and on posterior to last ray of dorsal and anal fins where cycloid scales are present. Axillary scale present in pelvic fin. Anal fin scale sheath with three, in most specimens four horizontal scale rows over base of anteriormost anal-fin rays, covering onefith of length of anterior fin rays; number of horizontal scale rows gradually decreasing posteriorly to one scale row over posteriormost rays. Caudal fin rays base covered by scales.

Mouth terminal, obliquely oriented relative to horizontal body axis. Upper jaw slightly more anteriorly projected than lower jaw. Posterior margin of maxilla extending beyond vertical through posterior margin of orbit. Infraorbitals 1 to 6 present, supraorbital absent, posterior margin of infraorbital 3 not reaching preopercle, posterior margin of infraorbital 4 not reaching preopercle in most examined specimens. Teeth conical. Premaxilla with two teeth rows, inner row with two teeth oriented to interior of mouth, outer row with 7 (1), 8 (6), 9 (23), 10 (47), 11 (20), 12 (11), or 13 (3) teeth, medialmost and lateralmost teeth canine. Maxilla with 39 (2), 40 (1), 41 (5), 42 (7), 43 (10), 44 (8), 45 (11), 46 (7), 47 (6), 48 (10), 49 (10), 50 (11), 51 (7), 52 (6), 53 (4), 54 (1), 55 (2), 56 (2), or 57 (1) conical teeth distributed along entire ventral margin. Dentary with two teeth rows. Inner row with 7 (3), 8 (28), 9 (35), 10 (19), 11 (4), or 12 (2) teeth posteriorly oriented. Outer row with anterior group formed by four canine teeth, third larger, first and fourth usually of similar size, some specimens with fourth tooth intermediate in size between third and first teeth, second tooth smallest and more external. Space between third and fourth canines occupied by lateral premaxillary canine when mouth is closed. Posterior group of outer teeth with 17 (1), 21 (1), or 26 (1) small conical teeth forming row adjacent and continuous to forth canine. One to three small conical teeth between third and fourth canines of outer row of dentary (Fig. 7c).

Lateral line complete. Lateral-line tube present between bases of middle caudal-fin rays. Lateral-line scales 90-105 (112) (Tab. 1), laterosensory canal on each scale with one posteroventral ramification; number of horizontal scale rows between dorsal-fin origin and lateral line 17-20 (102) (Tab. 2 ); number of horizontal scale rows between lateral line and pelvic-fin origin 14-16 (112) (Tab. 3); number of horizontal scale rows around caudal peduncle 23 (7), 24 (24), 25 (33), 26 (17), or 27 (8).
Total number of vertebrae 40 (1) or 41 (21), abdominal vertebrae 16 (22), caudal vertebrae 24 (1) or 25 (21). Supraneurals 4 (18) or 5 (1) obliquely oriented, proximal tip more anterior than distal tip, anteriormost supraneural lying anterior to neural spine of fifth vertebra, fourth supraneural lying between neural spines of seventh and eighth vertebrae. Fifth supraneural, when present, lying anterior to neural spine of ninth vertebra, vertically oriented.

Pseudotympanum present, bordered anteroventrally by obliquus superioris muscle, posteriorly by obliquus superioris muscle and by rib associated with sixth vertebra, posterodorsally by lateralis superficialis muscle and lateralline nerve. Rib associated with fifth vertebra visible anteriorly, but not bordering muscle hiatus anteriorly (Fig. 9).

Coloration. Overall body coloration yellowish, dorsal region darker than ventral region due to presence of chromatophores distributed on posterior field of dorsal scales, mainly near scale margins. Dorsal median dark band from supraoccipital spine to dorsal-fin origin, not distinguishable posterior to dorsal-fin base.

Dorsal region of head darker until approximately horizontal line through dorsal margin of orbit. A few specimens with scattered chromatophores on infraorbitals, mainly on 4, 5 and 6 . Skin bordering mouth more pigmented on premaxilla, maxilla and dentary, mainly on base of canine teeth of lower jaw. Lateral surface of maxilla with sparse chromatophores anteriorly to approximately half of bone length.

Oval shaped blotch on humeral region, largest diameter along vertical axis. A few specimens with crescent shaped humeral blotch with tips of crescent pointed anteriorly (Fig. 23b).

Silvery midlateral longitudinal band on body, dorsal to lateral line, ventral margin of band reaching lateral line in most specimens. Longitudinal band extending from posterior margin of supracleithrum to posterior margin of hypural plate, narrower at anterior- and posteriormost regions in most specimens, broader at region of vertical through dorsal-fin base. Silvery midlateral longitudinal band widening from caudal peduncle to margin of hypural plate in some specimens, and with ventral margin of silvery midlateral longitudinal band extending beyond lateral line on region of caudal peduncle.

Dark midlateral longitudinal band dorsal to lateral line extending from posterior margin of supracleithrum to approximately half length of middle caudal-fin rays, narrower at anterior- and posteriormost regions, broader at region of vertical through dorsal-fin base. Dark midlateral longitudinal band forming a diamond shaped blotch at caudal peduncle and base of median caudal-fin rays. Dark midlateral longitudinal band not as wide as silvery midlateral longitudinal band except on caudal peduncle region. Dorsal margin of two longitudinal bands usually overlap. 


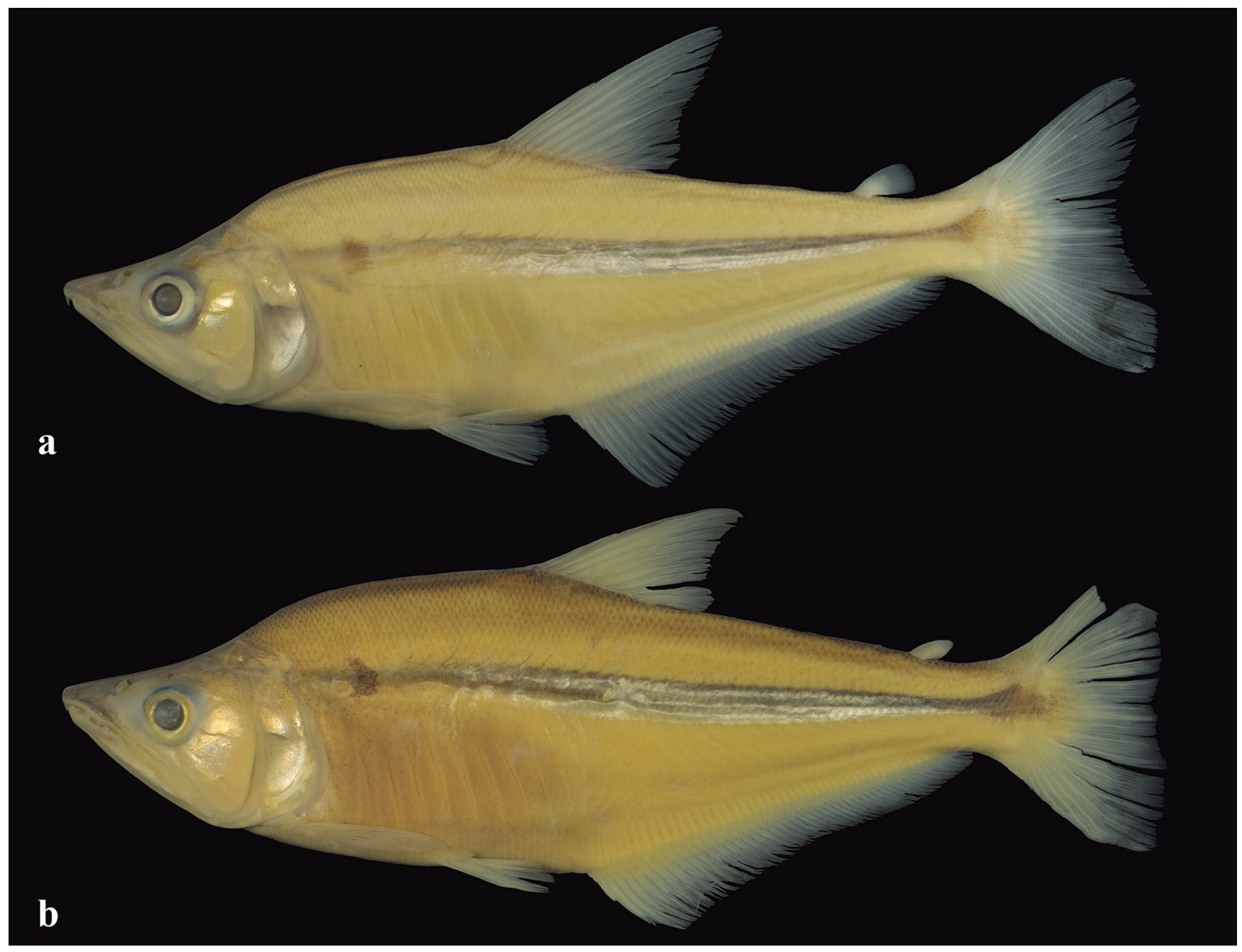

Fig. 23. Galeocharax humeralis. a. MZUSP 78865, $124.3 \mathrm{~mm}$ SL. Brazil, Mato Grosso, rio Paraguai basin, rio Cachoeirinha, and b. MZUSP 89961, $187.4 \mathrm{~mm}$ SL. Brazil, Mato Grosso, rio Paraguai basin, rio Sepotuba.

Specimens smaller than $126.0 \mathrm{~mm}$ SL with lines of chromatophores ventral to lateral line, following myosepta on lateral surface of body, region dorsal of anal-fin base and anal-fin rays.

Pectoral and pelvic fins hyaline. Dorsal fin with lines of chromatophores along rays and scattered chromatophores on interradial membrane. Adipose fin pale on most specimens, adipose fin with similar pattern of chromatophore distribution of dorsal region of body in a few specimens. Arched vertical line of chromatophores on base of caudal-fin base absent.

Sexual dimorphism. Males of Galeocharax humeralis have bony hooks on pelvic- and anal-fin rays. Bony hooks on anal-fin rays located on lateral surface of posterior branch of branched rays; bony hooks present on last unbranched ray in a few specimens. One or two, rarely three hooks per ray segment, dorsoposteriorly oriented (Figs. 10a-c). Bony hooks present on 12 to 27 anteriormost rays. Bony hooks on pelvic fin located on ventral surface of lepidotrichia, slightly posteriorly displaced on posterior surface of posterior branch of branched rays. One or two, rarely three hooks per segment pointing towards base of ray (Fig. 11). Hooks present on two to six lateralmost rays.

Two relatively large sized females (MZUSP 90473210.5 $\mathrm{mm} \mathrm{SL}$ and MCP $28624157.4 \mathrm{~mm} \mathrm{SL}$ ) have bony hooks on anal fin, however less developed, smaller in number and distributed on fewer rays compared to males (Figs. 10d-f).

\section{Geographical distribution. Galeocharax humeralis} occurs in the rio Paraguai, rio Uruguai and lower rio Paraná basins (Fig. 12). The only record of G. humeralis in the upper rio Paraná is in the Itaipu reservoir (NUP 255, 3 specimens 163.7-222.3 mm SL). Those specimens were collected between 1986 and 1989. With the formation of the Itaipu Reservoir, in October of 1982 some fish species that occurred in the $150 \mathrm{~km}$ stretch between Sete Quedas (Guaíra) and the Itaipu Power Plant (Foz do Iguaçu), became established above the former basins divider, that currently is the Itaipu Power Plant (Graça, Pavanelli, 2007). More detailed studies are necessary in order to understand if the presence of the species in this region is associated with this event. 
Remarks. Hydrocyon humeralis $(=G$. humeralis) was described based on an illustration from material deposited in the collection of the MNHN by D'Orbigny (Valenciennes 1834), with no further description. Valenciennes (1847) refered to the drawing of the previous publication and presented a brief description of the species. A more complete description was presented by Valenciennes (1849), who included the species in the genus Cynopotamus. The type locality was indicated as Buenos Aires, Argentina. Valenciennes (1849: 321) pointed out that the type specimen of Cynopotamus humeralis was obtained in a market at Buenos Aires, thus it would be more adequate to infer that the specimen originated in some locality within the río de La Plata basin.

The first mention that we found in the literature to the holotype of G. humeralis was made by Bertin (1948) in a catalogue of the types deposited in the Muséum National d'Histoire Naturelle in Paris.
The holotype of G. humeralis (MNHN 9848, $117.6 \mathrm{~mm}$ SL, Fig. 24) was not examined during this study, however data of the specimen is available in the literature (Tab. 5).

There are a few discrepancies among the data of the holotype presented by Valenciennes (1849) and Géry, Vu-TânTuê (1963a). The number of lateral line scales presented by Valenciennes (1849) and the number of scales below the lateral line presented by Géry, Vu-Tân-Tuê (1963a) also fall outside the range of variation presented herein. These differences could be explained by different ways of counting scales and by the fact that the scales below the lateral line are somewhat disorganized, leading to some imprecision of the counts.

Meristic and morphometric data of specimens from the rio Uruguai basin are included within the variation range of the data of specimens from the rio Paraguai drainages. The few specimens that were examined from the lower rio Paraná basin do not differ from specimens from the rio Paraguai and Uruguai basins.

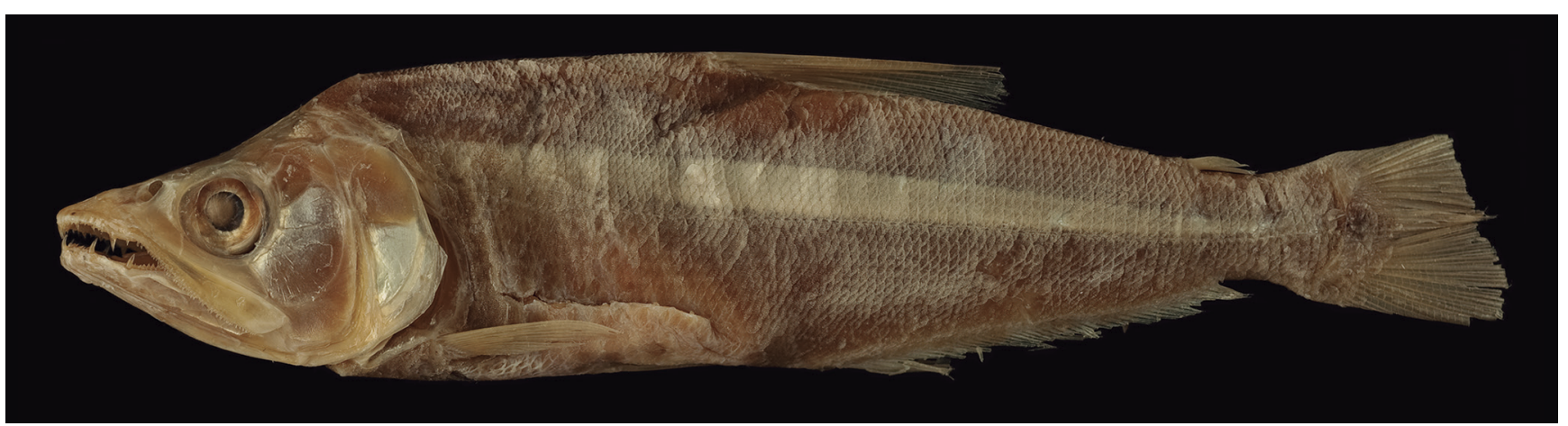

Fig. 24. Holotype of Hydrocyon humeralis Valenciennes, MNHN 9848, 117.6 mm SL.

Material examined. Brazil: Mato Grosso: INPA 2029, 2, 90.587.7 mm SL; MNRJ 21678, 1, 90.5 mm SL; MZUSP 4413, 1, 136.5 mm SL; MZUSP 19887, 3, 132.2-152.8 mm SL; MZUSP 19907, 3, 111.5-144.4 mm SL; MZUSP 19982, 4, 89.5-204.8 mm SL; MZUSP 19984, 5, 1 c\&s, 72.2-79.5 mm SL; MZUSP 27684, 1, 140.4 mm SL; MZUSP 42755, 1, 91.6 mm SL; MZUSP 56752, 1; MZUSP 56758, 1; MZUSP 78865, 1, 124.3mm SL; MZUSP 89961, 5, 142.2-195.4 mm SL; MZUSP 90224, 6, 135.7-229.9 mm SL; MZUSP 90473, 2, 174.4-210.5 mm SL; MZUSP 90680, 4, 137.9-170.1 mm SL; MZUSP 90684, 3, 124.6-171.5 mm SL; NUP 912, 11, 91.8-251.8 mm SL; NUP 3464, 10, 87.8-224.6 mm SL; NUP 3541, 4, 142.8-169.1 mm SL; NUP 4283, 6, 123.9-203.6 mm SL; NUP 7927, 1, 248.0 mm SL; NUP 8499, 1, 162.4 mm SL; NUP 11343, 2, 139.3-145.8 mm SL. Mato Grosso do Sul: MZUSP 19901, 1, 204.7 mm SL; NUP 1927, 1, 214.8 mm SL. Paraná: MZUSP 19851, 8, 210.4-235.1 mm SL; NUP 255, 3, 163.7-222.3 mm SL. Rio Grande do Sul: MCP 6949, 1, 127.4 mm SL; MCP 10950, 1, 159.8 mm SL; MCP 11751, 6, 218.7163.6 mm SL; MCP 11897, 2, 146.1-158.4 mm SL; MCP 12392, 1, 198.9 mm SL; MCP 12437, 1, 201.1 mm SL; MCP 13191, 1, $126.8 \mathrm{~mm}$ SL; MCP 13217, 1, $130.1 \mathrm{~mm}$ SL; MCP 13283, 2, 126.5-138.7 mm SL; MCP 13298, 4, 127.9-204.3 mm SL; MCP 13522, 1, 196.7 mm SL; MCP 13523, 3, 112.3-180.3 mm SL;
MCP 13531, 1, 126.3 mm SL; MCP 16803, 6, 151.6-249.4 mm SL; MCP 19019, 3, 144.1-164.5 mm SL; MCP 28624, 7, 150.8$202.3 \mathrm{~mm}$ SL; MZUSP 40967, 1, $176.6 \mathrm{~mm}$ SL. Santa Catarina: MCP 18618, 1, 174.2 mm SL; MCP 19020, 4, 157.1-207.9 mm SL; MCP 20401, 7, 108.1-197.4 mm SL; MCP 20742, 10, 125.4$234.9 \mathrm{~mm}$ SL; MCP 21350, 2, 240.6-241.1 mm SL.

\section{Discussion}

The examination of a large number of specimens, including many from areas not sampled at the time of the last taxonomic study of Galeocharax (Menezes, 1976), made possible to corroborate previous hypotheses present in the literature, such as the recognition of $G$. humeralis and $G$. goeldii as two distinct species. In addition, the diagnostic characters and the information on the geographical distribution of these two species were refined.

The present study also provided evidence for alternative interpretations as to the pattern of geographic variation of the specimens from the rio Amazonas, rio Tocantins, rio Orinoco, and the upper rio Paraná basins, with implications in the number of species that may be recognized in these drainages. It was observed that recognizing the specimens 
from the rio Amazonas and the upper rio Paraná basins as distinct species (G. gulo and G. knerii, respectively), would be problematic due to the high degree of overlap of the diagnostic characters previously proposed for these species (Menezes 1976: 41). Although differences between the two nominal species G. gulo and G. knerii were not corroborated in this study, the increase in the number of specimens from the rio Tocantins and río Orinoco basins provides new insights about the pattern of distribution of the variation of meristic characters of Galoecharax. Specimens from the rio Tocantins and the upper rio Paraná are more similar to each other, the same being valid for the specimens from the rio Amazonas and the rio Orinoco basins. Specimens from the rio Tocantins basin show some apparently different characteristics such as tendencies to have fewer vertebrae and branched anal-fin rays.

Specimens from the rio Tapajós basin also show some differences in a few characteristics. Additional data from specimens from that drainage would provide a better understanding of the limits of geographic variation of $G$. gulo.

The hiatus in the geographic distribution of Galeocharax in the rio Xingu basin and the small number of collected specimens from the rio Tapajós basin are noteworthy, rendering new collecting efforts in the area important to check for the presence of species of the genus in the rio Xingu as well as to better document the morphological variation of the specimens from the rio Tapajós basin.

Mature males of the three species of Galeocharax have bony hooks on the pelvic and anal fins (Figs. 10a-c, 11). As mentioned above, some females of Galeocharax gulo and G. humeralis examined in this study also have bony hooks on the anal fin rays (Fig. 10d-f). The presence of bony hooks on females of Characiformes is fairly uncommon, but it was previously reported on the pelvicfin rays of the genus Cheirodon (Malabarba, 1998: 210, fig. 16b female of Cheirodon interruptus), and on the anal-fin rays of Astyanax jordanensis (Vera Alcaraz et al., 2009: 188), Brycon sp. n. "Pardo" (Lima, 2001: 58) and Hyphessobrycon socolofi according to T. Teixeira (oral communication, March, 2016). The presence of bony hooks should be better investigated in females of other Characiformes.

\section{Acknowledgments}

This work was carried out at the Departamento de Zoologia, Instituto de Biociências, Universidade de São Paulo. The institution is acknowledged for providing workspace and access to facilities. The authors are grateful to Osvaldo Oyakawa and Michel Gianeti (MZUSP), Carlos Lucena (PUCRS), Vinicius Bertaco and Marco Azevedo (Fundação Zoobotânica do Rio Grande do Sul), Carolina Doria and Andrea Paixão (UNIR), Marcelo Britto and Paulo Buckup (MNRJ), Paulo Lucinda and Everton Oliveira (UNT), Hernán Ortega (MUSM), Junior Chuctaya and Dario Fuster (UFRGS), Homero Sanches (Instituto de Investigaciones de la Amazonía Peruana), Carla Pavanelli and Fagner de Souza (Nupelia), Jansen Zuanon and Lucia Rapp Py-Daniel (INPA), Otto Castillo (MCNG), Mark Sabaj (ANSP), Sandra Raredon (USNM), Barbara Brown (AMNH), Zora Gabsi (MNHN) for museum and technical support and/or loan of specimens. Kyle Luckenbill (ANSP), Zora Gabsi (MNHN) and Anja Palandacic (NMW) are acknowledged for photographs and radiographs of type material. Kleber Leite helped to produce figure 9. Radiographs were produced with the help of Ana Carolina Pinto, Stefano Hagen and the technicians Hugo Idalgo and Reginaldo Silva of the Faculdade de Medicina Veterinária, USP. Enio Mattos and Philip Lenktaitis are acknowledged for help on producing the SEM images. Authors thank Flavio Lima and two anonymous reviewers for helpful criticism on this manuscript and Karla Soares for providing bibliographic references. VG was supported by a master's fellowship from CAPES and by PROEX program from the Programa de Pós-Graduação em Zoologia of the Departamento de Zoologia IB-USP. MTP acknowledges partial funding from Conselho Nacional de Desenvolvimento Científico e Tecnológico - CNPq (proc. no. 307067/2010-6). Optical microscopy images were produced with Zeiss Discovery V20 stereomicroscope with a Zeiss Axiocam digital camera attached, which was a benefit from Projeto Saci - South American Characiformes Inventory (FAPESP proc. $\mathrm{n}^{\circ}$ 2011/50282-7, http://www.projeto-saci.com).

\section{References}

Apone F, Oliveira AK, Garavello JC. Composição da ictiofauna do rio Quilombo, tributário do rio Mogi-Guaçu, bacia do alto rio Paraná, sudeste do Brasil. Biota Neotropica. 2008; 8(1):93107.

Arámburu ASA. Contribución a la sistematica de los peces carácidos llamados "dientudos". Notas del Museo, Facultad de Ciencias Naturales y museo de la Universidad Nacional de Eva Perón. 1953; 16(145):298-320.

Barthem R, Goulding M, Forsberg B, Cañas C, Ortega H. Aquatic ecology of the rio Madre de Dios. Scientific bases for AndesAmazon headwaters conservation. Lima: Asociación para la Conservación de la Cuenca Amazónica (ACCA)/Amazon Conservation Association (ACA); 2003.

Bertin L. Catalogue des types de poissons du Muséum National d'Histoire Naturelle. 3e partie. Ostariophysaires (Characiniformes, Gymnotiformes). Bayeux: Imp. Colas; 1948.

Bogotá-Gregory JD, Maldonado-Ocampo JA. Peces de la zona hidrogeográfica de la Amazonia, Colombia. Biota Colombiana. 2006; 7(1):55-94.

Boulenger GA. An account of the fishes collected by Mr. C. Buckley in eastern Ecuador. Proc Zool Soc London. 1887; 274-283.

Boulenger GA. On a collection of fishes from the Rio Juruá, Brazil. The Transactions of the Zoological Society of London. 1898; 14(7):421-428. 
Brandão H, Toledo GM, Wunderlich AC, Ramos IP, Carvalho ED, Silva RJ. Ocurrence of Braga cigarra (Cymothoidae) parasitizing Galeocharax knerii (Characidae) from affluents of Jurumirim reservoir, Brazil. Rev Bras Parasitol Vet. 2013; 22(2):292-296.

Brandão $\mathrm{H}$, Vidotto-Magnoni $\mathrm{AP}$, Ramos IP, Carvalho ED. Assessment of the ichthyofauna in stretches under the influence of Salto Grande Reservoir (Middle Paranapanema River, SP/ PR, Brazil). Acta Limnol Bras. 2009; 21(4):452-463.

Britski, HA, Silimon KZS, Lopes BS. Peixes do Pantanal. Manual de Identificação. Corumbá: Embrapa-CPAP; 1999.

Buckup PA, Menezes NA, Ghazzi MS. Catálogo de Peixes de Água Doce do Brasil. Rio de Janeiro: Museu Nacional; 2007.

Copatti CE, Zanini LG, Valente A. Ictiofauna da microbiologia do rio Jaguari, Jaguari/RS, Brasil. Biota Neotropica. 2009; 9(2):179-186.

Cope ED. Contribution to the ichthyology of the Marañon. Proc Am Philos Soc. 1870; 11(81):559-570.

Eigenmann CH. New genera of South American fresh-water fishes, and new names for some old genera. Smithson Misc Collec. 1903; 45:144-148.

Eigenmann CH. Fowler's "Heterognathous Fishes" with a note on the Stethaprioninae. Am Nat. 1907; 41(492):767-772.

Eigenmann $\mathrm{CH}$. Catalogue of the fresh-water fishes of tropical and south temperate America. In: Scott, WB, editor. Reports of the Princeton University expeditions to Patagonia 1896-1899. Princeton: Princeton University; 1910. vol. 3, Zöology, pt. 4; p.375-511.

Eigenmann CH, Allen WR. Fishes of Western South America: The Intercordilleran and Amazonian Lowlands of Peru. The High Pampas of Peru, Bolivia, and Northern Chile. With a revision of the Peruvian Gymnotidae and of the genus Orestias. Lexington: University of Kentucky; 1942. pts. 1-2.

Eigenmann CH, Eigenmann RS. A catalogue of the fresh-water fishes of South America. Proc U S Natl Mus. 1891; 14(842):1-81.

Eigenmann CH, McAtee WL, Ward DP. On further collections of fishes from Parguay. Ann Carnegie Mus. 1907; 4(2):110-157.

Eigenmann $\mathrm{CH}$, Norris AA. Sobre alguns peixes de S. Paulo, Brasil. Revista do Museu Paulista. 1900; 4:349-362.

Fowler HW. Note on the Odontostomidae. Proc Acad Nat Sci Philadelphia. 1901; 53:211-212.

Fowler HW. Note on the Characinidae. Proc Acad Nat Sci Philadelphia. 1904; 56(1):119.

Fowler HW. Further knowledge of some heterognathous fishes. Part II. Proc Acad Nat Sci Philadelphia. 1907; 58:431-483.

Fowler HW. The proper restriction of Eucynopotamus. Science. 1910; 31(803):790.

Fowler HW. Fishes of the Madeira River, Brasil. Proc Acad Nat Sci Philadelphia. 1913; 65(3):517-579.

Fowler HW. A collection of fishes obtained by Mr. William C. Morrow in the Ucayali River Basin, Peru. Proc Acad Nat Sci Philadelphia. 1940; 91:219-289.

Fowler HW. Los peces del Peru. Catalogo sistematico de los peces que habitan em aguas peruanas. Lima: Museo de Historia Natural Javier Prado, Universidad Mayor de San Marcos; 1945.

Fowler HW. Os peixes de água doce do Brasil. Arq Zool. 1950; 6:205-404.

Freitas IS, Lucinda PHF, Soares AB, Pelicice FM, Akama A. Variações espaciais na estrutura da ictiofauna entre os ambientes do reservatório de Peixe Angical. In: Agostinho CS,
Pelicice FM, Marques, EE, organizers. Reservatório de Peixe Angical: Bases ecológicas para o manejo da ictiofauna. São Carlos: RiMa Editora; 2009. p.41-49.

Fricke R, Eschmeyer WN. Guide to fish collections [Internet]. San Francisco: California Academy of Sciences; 2016 [updated 2016 Dec 01; cited 2016 Dec 19]. Available from: http:// researcharchive.calacademy.org/research/ichthyology/catalog/ collections.asp

Galvis G, Mojica JI, Duque SR, Castellanos C, Sánchez-Duarte P, Arce M, Gutiérrez A, Jiménez LF, Santos M, Vejarano S, Arbeláez F, Prieto E, Leiva M. Peces del medio Amazonas: Región de Leticia. Bogotá: Conservación Internacional; Editorial Panamericana, Formas e Impresos; 2006. (Guías Tropicales de Campo; no. 5).

Gandini CV, Boratto IA, Fagundes DC, Pompeu PS. Estudo da alimentação dos peixes no rio Grande à jusante da usina hidrelétrica de Itutinga, Minas Gerais, Brasil. Iheringia Ser Zool. 2012; 102(1):56-61.

Garman SW. On the species of Cynopotamus. Bulletin of the Essex Institute. 1890; 22(1-3):11-14.

Gealh AM. Ictiofauna dos rios Fortaleza, Iapó, alto e médio Tibagi. In: Melo MS, Moro RS, Guimarães GB, editors. Patrimônio Natural dos Campos Gerais do Paraná. Ponta Grossa: Editora UEPG; 2007. p.151-162.

Géry J. Corrected and suplemented descriptions of certain characoid fishes described by Henry W. Fowler, with revisions of several of their genera. Stud Neotrop Fauna Environ. 1972; 7(1):1-35.

Géry J. Characoids of the world. Neptune City: T. F. H. Publications; 1977.

Géry J, Vu T-T. Définitions de Cynopotamus Val. et genres voisins (Pisces, Characoidei). Bull Mus Natl Hist Nat. 1963a; 35(2): 143-150.

Géry J, Vu T-T. Définitions de Cynopotamus Val. et genres voisins (Pisces, Characoidei) (Suite). III. Definitions et Clés des genres et des espèces. Bull Mus Natl Hist Nat. 1963b; 35(3):238-246.

Godoy MP. Peixes do Brasil: subordem Characoidei: bacia do rio Mogi Guassu. Piracicaba: Franciscana; 1975. vol. 2.

Goeldi EA. Primeira contribuição para o conhecimento dos peixes do vale do Amazonas e das Guyanas. Estudos ichthyologicos dos anos 1894-1898. Boletim do Museu Paraense de História Natural e Ethnographia. 1898; 2(4):443-488.

Gomiero LM, Braga FMS. Fish, Corumbataí and Jacaré-Pepira river basins, São Paulo State, Brazil. Check List. 2006; 2(1):57-67.

Goulding M, Barthem R, Ferreira E. The Smithsonian Atlas of the Amazon. Washington (DC): Smithsonian Institution Press; 2003a.

Goulding M, Cañas C, Barthem R, Forsberg B, Ortega H. Amazon Headwaters. Rivers, wildlife and conservation in Southeastern Peru. Lima: Gráfica Biblos; 2003b.

Graça WJ, Pavanelli CS. Peixes da planície de inundação do alto rio Paraná e áreas adjacentes. Maringá: Eduem; 2007.

Günther A. Catalogue of fishes in the British Museum. London: British Museum Natural History; 1864. vol. 5

International Commission on Zoological Nomenclature (ICZN). International Code of Zoological Nomenclature. 4th ed. London: International Trust for Zoological Nomenclature Natural History Museum; 1999.

Júlio Júnior HF, Cunico AM, Gubiani EA, Fernandes R, Dias RM, Graça WJ, Gomes LC. Ictiofauna. In: Agostinho AA, Thomaz SM, Rodrigues L, Gomes LC. A Planície de inundação do alto rio Paraná. Maringá: UEM/Nupelia/PEA; 2003. p.77-99. 
Kner R. Zur Familie Characinen. II. Folge der ichthyologischen Beiträge. Denkschr K Akad Wiss Wien. 1860; 18:9-62.

La Monte FR. Fishes from Rio Juruá and Rio Purus, Brazilian Amazonas. Amer Mus Novit. 1935; (784):1-8.

Langeani F, Castro RMC, Oyakawa OT, Shibatta OA, Pavanelli CS, Casatti L. Diversidade da ictiofauna do alto rio Paraná: composição atual e perspectivas futuras. Biota Neotropica. 2007; 7(3):181-197.

Langeani F, Rêgo ACL. Guia ilustrado dos peixes da bacia do rio Araguari. Uberlândia: Grupo de Mídia Brasil Central; 2014.

Lasso CA, Mojica JI, Usma JS, Maldonado-Ocampo JA, DoNascimiento C, Taphorn DC, Provenzano F, Lasso-Alcalá OM, Galvis G, Vásques L, Lugo M, Machado-Allison A, Royero R, Suárez C, Ortega-Lara A. Pesces de la cuenca del río Orinoco. Parte I: lista de espécies y distribución por subcuencas. Biota Colombiana. 2004; 5(2):95-158.

Le Bail P-Y, Covain R, Jégu M, Fisch-Muller S, Vigouroux R, Keith P. Updated checklist of the freshwater and estuarine fishes of French Guiana. Cybium. 2012; 36(1):293-319.

Lima FCT. Revisão taxonômica do gênero Brycon Müller \& Troschel, 1844, dos rios da América do Sul cisandina (Pisces, Ostariophysi, Characiformes, Characidae). [MSc. Dissertation]. São Paulo, SP: Universidade de São Paulo; 2001.

Lima FCT, Pires THS, Ohara WM, Jerep FC, Carvalho FR, Marinho MMF, Zuanon J. Characidae. In: Queiroz LJ, Torrente-Vilara G, Ohara WM, Pires THS, Zuanon J, Doria CRC, organizers. Peixes do rio Madeira. São Paulo: Dialeto Latin American Documentary; 2013. p.213-395. vol. 1.

López HL, Menni RC, Miquelarena AM. Lista de los peces de água dulce de la Argentina. Biología Acuática. 1987; 12:1-50.

López, HL, Miquelarena AM, Menni RC. Lista comentada de los peces continentales de la Argentina. La Plata, Buenos Aires: Museo de la Plata; 2003. (ProBiotA, Série Técnica y Didática; no. 5).

Lowe-McConnell RH. Natural history of fishes in Araguaia and Xingu Amazonian tributaries, Serra do Roncador, Mato Grosso, Brazil. Ichthyol Explor Freshw. 1991; 2(1):63-82.

Lucena CAS. Relações filogenéticas e definição do gênero Roeboides Günther(Ostariophysi: Characiformes: Characidae). Comunicações do Museu de Ciências da PUCRS, Série Zoologia. 1998; 11:19-59.

Lucena CAS, Menezes NA. Subfamily Characinae. In: Reis RE, Kullander SO, Ferraris CJ, Jr., organizers. Check list of the freshwater fishes of South and Central America. Porto Alegre: Edipucrs; 2003. p.200-208.

Magalhães ALB, Bazzoli N, Santos GB, Rizzo E. Reproduction of the South American dogfish characid, Galeocharax knerii, in two reservoirs from upper Paraná River basin, Brazil. Environ Biol Fishes. 2004; 70(4):415-425.

Malabarba LR. Monophyly of the Cheirodontinae, characters and major clades (Ostariophysi: Characidae). In: Malabarba LR, Reis RE, Vari RP, Lucena ZMS, Lucena CAS, editors. Phylogeny and Classification of Neotropical Fishes. Porto Alegre: Edipucrs; 1998. p.193-233.

Maldonado-Ocampo JA, Vari RP, Usma JS. Checklist of the freshwater fishes of Colombia. Biota Colombiana. 2008; 9(2):143-237.

Mattox GMT, Toledo-Piza M. Phylogenetic study of the Characinae (Teleostei: Characiformes: Characidae). Zool J Linn Soc. 2012; 165(4):809-915.

Menezes NA. Systematics and evolution of the tribe Acestrorhynchini (Pisces, Characidae). Arq Zool. 1969; 18(1-2):1-150.
Menezes NA. On the Cynopotaminae, a new subfamily of Characidae (Osteichthyes, Ostariophysi, Characoidei). Arq Zool. 1976; 28(2):1-91.

Menezes NA. Three new species of the characid genus Cynopotamus Valenciennes, 1849, with remarks on the remaining species (Pisces, Characiformes). Beaufortia. 1987; 37(1):1-9.

Menezes NA. Description of five new species of Acestrocephalus Eigenmann and redescription of $A$. sardina and $A$. boehlkei (Characiformes: Characidae). Neotrop Ichthyol. 2006; 4(4):385-400.

Menezes NA. Charax goeldii Fowler, 1913 a valid species of Galeocharax Fowler (Characiformes: Characidae). Neotrop Ichthyol. 2007a; 5(1):21-24.

Menezes NA. A new species of Cynopotamus Valenciennes, 1849 (Characiformes, Characidae) with a key to the species of the genus. Zootaxa. 2007b; 1635:55-61.

Mérona B, Juras AA, Santos GM, Cintra IHA. Os peixes e a pesca no baixo rio Tocantins: vinte anos depois da UHE Tucuruí. Brasília, DF: Eletrobras Eletronorte; 2010.

Milko P. Peixes do rio Paranapanema. São Paulo. Horizonte Geográfico; 2003.

Mirande JM. Phylogeny of the family Characidae (Teleostei: Characiformes): from characters to taxonomy. Neotrop Ichthyol. 2010; 8(3):385-568.

Mojica JI, Galvis G, Arbeláez F, Santos M, Vejarano S, PrietoPiraquive E, Arce M, Sánchez-Duarte P, Castellanos C, Gutiérrez A, Duque SR, Lobón-Cerviá J, Granado-Lorencio C. Peces de la cuenca del río Amazonas em Colombia: Región de Leticia. Biota Colombiana. 2005; 6(2):191-210.

Monteiro AS, Oliveira AHM, Pelicice FM, Oliveira RJ. Alterações na disponibilidade de recursos alimentares e na dieta das principais espécies de peixes. In: Agostinho CS, Pelicice FM, Marques EE, organizers. Reservatório de Peixe Angical: Bases ecológicas para o manejo da ictiofauna. São Carlos: RiMa Editora; 2009. p.77-86.

Müller J, Troschel FH. Synopsis generum et specierum familiae Characinorum. Arch Naturgesch. 1844; 10(1):81-99.

Müller J, Troschel FH. Horae Ichthyologicae. Beschreibung und Abbildung neuer Fische. Die Familie der Characinen. Erstes und Zweites Heft. Berlin: Viet \& Comp; 1845.

Nelson JS, Grande TC, Wilson MVH. Fishes of the World. 5th edition. Hoboken: John Wiley \& Sons, Inc.; 2016.

Neuberger AL, Marques EE, Agostinho CS, Pelicice FM. Variações espaciais na atividade reprodutiva de peixes na área de influência do reservatório de Peixe Angical. In: Agostinho CS, Pelicice FM, Marques EE, organizers. Reservatório de Peixe Angical: Bases ecológicas para o manejo da ictiofauna. São Carlos: RiMa Editora; 2009. p.59-68.

Oliveira C, Avelino GS, Abe KT, Mariguela TC, Benine RC, Ortí G, Vari RP, Castro RMC. Phylogenetic relationships within the speciose family Characidae (Teleostei: Ostariophysi: Characiformes) based on multilocus analysis and extensive ingroup sampling. BMC Evol Biol. 2011; 11:275.

Ortega H, Hidalgo M, Trevejo G, Correa E, Cortijo AM, Meza V, Espino J. Lista anotada de los peces de aguas continentales del Perú: Estado actual del conocimiento, distribución, usos y aspectos de conservación. Lima: Ministerio del Ambiente; 2012.

Ortega H, Mojica JI, Alonso JC, Hidalgo M. Listado de los peces de la cuenca del río Putumayo en su sector colombo-peruano. Biota Colombiana. 2006; 7(1):95-112. 
Ortega H, Vari RP. Annotated Checklist of the Freshwater Fishes of Peru. Washington (DC): Smithsonian Institution Press; 1986. (Smithsonian Contributions to Zoology; no. 437).

Pearson NE. The fishes of the Atlantic and Pacific slopes near Cajamarca, Peru. Proc Calif Acad Sci. 1937; 23(7):87-98.

Pelicice FM, Akama A, Oliveira RJ, Silva DS. Padrões espaciais e temporais na distribuição da ictiofauna, antes e após a formação do reservatório de Peixe Angical. In: Agostinho CS, Pelicice FM, Marques EE, organizers. Reservatório de Peixe Angical. Bases ecológicas para o manejo da ictiofauna. São Carlos: RiMa Editora; 2009. p.29-39.

Pellegrin J. Note sur les poissons recueillis par M. F. Geay dans l'Apuré et ses affluentes. Bull Mus Hist Nat. 1899; 5:156-159.

Pellegrin J. Characinidés du Brésil rapportés par M. Jobert. Bull Mus Nat Hist Nat. 1909; 15:147-153.

Perugia A. Appunti sopra alcuni sud-americani conservati nel Museo Civico di Storia Naturale di Genova. Ann Mus Civ Stor Nat Genova. 1891; 10:605-657.

Perugia A. Di alcuni pesci raccolti in Bolivia dal Prof. Luigi Balzan. Ann Mus Civ Stor Nat Genova. 1897; 18:16-27.

Petry AC, Agostinho AA, Gomes LC. Spatial variation of the fish assemblage structure from the upper rio Paraná floodplain, Brazil, in a dry year. Acta Limnol Bras. 2003; 15(1):1-13.

Planquette P, Keith P, Le Bail P-Y. Atlas des poissons d'eau douce de Guyane. Paris: IEGB; MNHN; INRA; CSP; Ministère de l'Environment; 1996. vol 1.

Rapp Py-Daniel L, Deus CP, Ribeiro OM, Sousa LM. Peixes. Peixes. In: Rapp Py-Daniel L, Deus CP, Henriques AL, Pimpão DM, Ribeiro OM, organizers. Biodiversidade do médio Madeira: bases científicas para propostas de conservação. Manaus: INPA; MMA; MCT; 2007. p.89-125.

Ribeiro Neto FB, Höfling JC, Ferreira LI, Romano CEA. Distribuição, reprodução e alimentação de Galeocharax knerii no reservatório de Salto Grande, macro-regiões de Campinas, SP. Bioikos. 1998; 12(2):19-25.

Roberts CD. Comparative morphology of spined scales and their phylogenetic significance in the Teleostei. Bull Mar Sci. 1993; 52(1):60-113.

Santos GM, Mérona B, Juras AA, Jégu M. Peixes do baixo rio Tocantins: 20 anos depois da Usina Hidrelétrica de Tucuruí. Brasília: Eletronorte; 2004.

Schultz LP. The fishes of the family Characinidae from Venezuela, with descriptions of seventeen new forms. Proc U S Natl Mus. 1944; 95(3181):235-367.

Schultz LP. Review of thirteen genera of South America fishes in the subfamilies Cynodontinae, Hepsetinae and Characinae, with description of a new Cyrtocharax. In: Hatch MH, editor. Studies honoring Trevor Kincaid. Seattle: University of Washington Press; 1950. p.43-73.
Shibatta OA, Dias JHP. 40 peixes do Brasil: CESP 40 anos. Rio de Janeiro: Doiis; 2006.

Silvano RAM, Oyakawa O, Amaral B, Begossi A. Peixes do alto rio Juruá (Amazonas, Brasil). São Paulo: Editora da Universidade de São Paulo; 2001.

Steindachner F. Zur Fisch-Fauna des Magdalenen Stromes. Denkschr K Akad Wiss Wien. 1879; 39:19-78.

Sverlij SB, Schenke RLD, López HL, Ros AE. Peces del rio Uruguay: Guia ilustrada de las especies mas comunes del río Uruguay inferior y el embalse de Salto Grande. Uruguay: Publicaciones de la Comision Administradora del río Uruguay; 1998.

Taphorn DC. The characiform fishes of the Apure river drainage, Venezuela. Biollania, Edición Especial (Monografias Cientificas del Museo de Ciencias Naturales). 1992;4:1-537.

Taylor WR, Van Dyke GC. Revised procedures for staining and clearing small fishes and other vertebrates for bony and cartilage study. Cybium. 1985; 9(2):107-119.

Valenciennes A. Poissons [plates]. In: D’Orbigny A. Voyage dans l'Amérique Méridionale. Paris: Pitois-Levrault; 1834. pl. 11, fig. 2.

Valenciennes A. Poissons: Catalogue des principales espèces de poissons, rapportées de l'Amérique méridionale. In: D’Orbigny A. Voyage dans l'Amérique Méridionale. Paris: Pitois-Levrault; 1847. p.1-11. vol. 5.

Valenciennes A. In: Cuvier G, Valenciennes A. Histoire Naturelle des Poissons. Paris: P. Bertrand: 1849. vol. 22.

Vaz MM, Torquato VC, Barbosa NDC. Guia ilustrado de peixes da bacia do rio Grande. Belo Horizonte: CEMIG/CETEC; 2000.

Vera Alcaraz HS, Pavanelli CS, Bertaco VA. Astyanax jordanensis (Ostariophysi: Characidae), a new species from the rio Iguaçu basin, Paraná, Brazil. Neotrop Ichthyol. 2009; 7(2):185-190.

Zaniboni Filho E, Meurer S, Shibatta OA, Nuñer APO. Catálogo Ilustrado de peixes do alto rio Uruguai. Florianópolis: Editora da UFSC; Tractebel Energia; 2004.

Zayas MA, Cordiviola E. The conservation state of Characidae fish (Pisces: Characiformes) in area of the Plata basin, Argentina. Gayana. 2007; 71(2):178-186.

Zeinad AK, Prado RA. Peixes fluviais do Brasil: espécies esportivas. São Paulo: Pescaventura; 2012.

Submitted March 30, 2016 Accepted December 8, 2016 by Fernando Carvalho 